Andrews University

Digital Commons @ Andrews University

1959

\title{
Modern Concepts of Mind and Body in the Light of the Teaching of the Bible and the Writings of Ellen G. White: A Comparative Study
}

Mabel Klopfenstein Gill

Andrews University

Follow this and additional works at: https://digitalcommons.andrews.edu/theses

Part of the Education Commons, Psychiatry and Psychology Commons, and the Religion Commons

\section{Recommended Citation}

Gill, Mabel Klopfenstein, "Modern Concepts of Mind and Body in the Light of the Teaching of the Bible and the Writings of Ellen G. White: A Comparative Study" (1959). Master's Theses. 152.

https://dx.doi.org/10.32597/theses/152

https://digitalcommons.andrews.edu/theses/152

This Thesis is brought to you for free and open access by the Graduate Research at Digital Commons @ Andrews University. It has been accepted for inclusion in Master's Theses by an authorized administrator of Digital Commons@ Andrews University. For more information, please contact repository@andrews.edu. 
This dissertation, written under the direction of the Chairman of the candidate's Guidance Committee and approved by all members of the Committee, has been presented to and accepted by the faculty of the School of Graduate Studies in partial fulfillment of the requirements for the Master of Arts degree.

Date

\section{Dean}

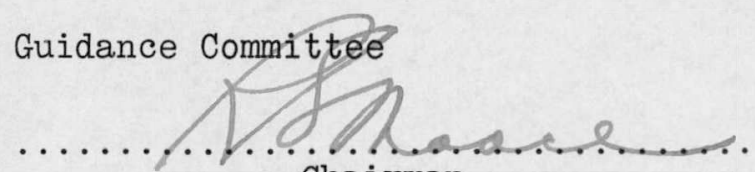
Chairman

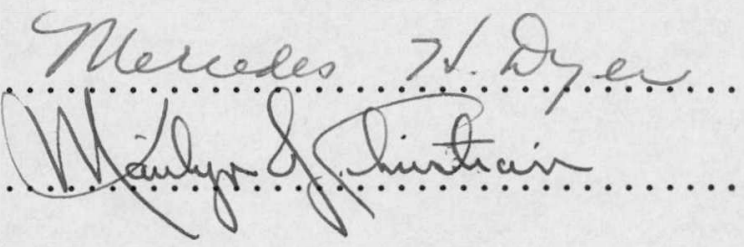




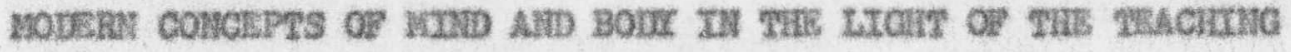

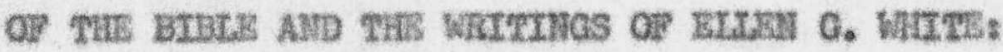

A COMPARATEV STUEY

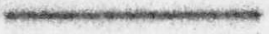 \\ A Thesis \\ Prosented to \\ the Faculty of the Sohool of Craduate Studies \\ Department of Eduea tion \\ Potonae University
}

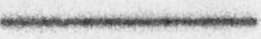

In Partzal Fulfaliment

of the Requirements for the Degree

Master of Arts
\end{abstract}

by

1abel. Xlopienstein 641工.

June 1959 
TABLE OF CONWWNS

CLAPTER

PAOS

I. TIS PROBIEN AWD DERIXTIOHS OF TSHS USED $\ldots \ldots \ldots$ Tho problem $\ldots \ldots \ldots \ldots \ldots \ldots$ Statement of the problein . . .......... 2 Inportance of thes study $\ldots \ldots \ldots 2$ Organization of the materla2 .......... 3 History and present status . . .......... 3 Sonzee of data and method of procedure . . . . . 4

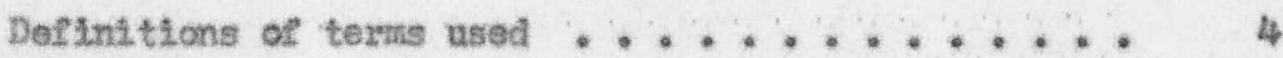
Hrtttngs of Wre. Wh1te .............. 4 Psychosanatic .................... 4 Functional disease , ................ 5 Neurosis ......................55 The antononte nervous syatem $\ldots \ldots \ldots 5$ The sympathetic divlsion of the autononic norvous system $, \ldots, \ldots, \ldots, \ldots, \ldots, \ldots, \ldots, \ldots, \ldots, \ldots$

The parasympathetic diviston of the autonomic nervous aysten,$\ldots \ldots \ldots \ldots$ The endonthe system ................ 5 The excoordne glands,$\ldots \ldots 6$ Ermotion $\ldots \ldots \ldots \ldots \ldots$

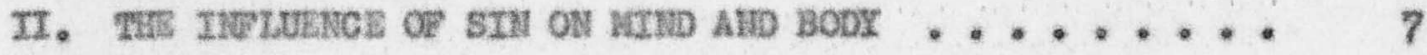

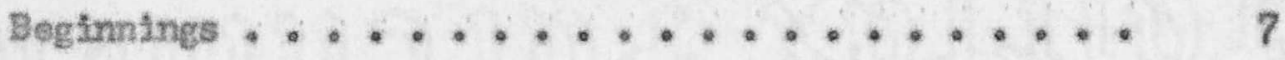
The 2 oss of $\mathrm{Cod}^{3} \mathrm{~s}$ presence................ 8 
CaPTEK PACE

How disanse origlnated .............. 9

The pattern of restoration ............ 20

Goneluston .................. 22

III. THE PSTCHOLOCTCAL BACKCROUND FOR MIIX AND BODY . . . . 13

Importance of plystolog ............ 13

Undonlyine prinotples ............. 14

Physteal mechanisms .............. 25

Resul ts of Imbalanced nervous function...... 27

How the autonomite nervous system produces disease..$\quad 18$

Other areas where the autononite funotions . . . . . 2

Hrse. White on autononie action ........... 2I.

Body chemlstry helps control belance......... 23

Condt tloning and paychosomatie disesse....... 25

Imagination and diseaso ............... 26

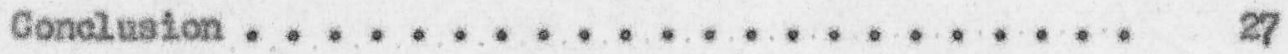

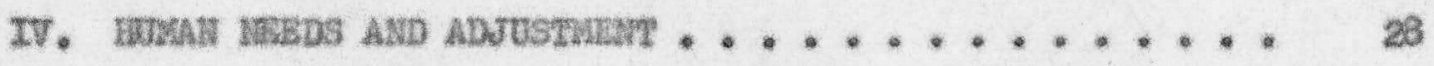

Universal needs and human behavior........... 28

Anxiety and uxuet needs .................. 31

The Christian's attitude .................. 32

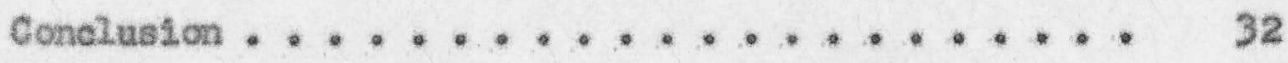

7. THE RELATION OF EWTROWuan TO Natid AND BODX ..... 34

Prenatal enviroment................. 34

Hone environsent .................... 37 
Discipline .......................

Daninoering diselpline ............ 40

Overindulgent diseipline ............ 42

Re jection and diserinination .......... 43

Inoonsistent diseipltne ............ 45

The atmogphere of the home .......... 45

Sehool environnent ................ 46

Compantonshtp ................... 48

Employment and anvironment ........... 49

The culture and mental hygtene ......... 50

Old age and emrironnent ............... 5 I.

Concluston ..................... 52

VI. CONSTITUTORAL MAKE-UP AS A PAGTOR IN MIRD-BOTI

RELATTOESETS $\ldots \ldots \ldots \ldots \ldots$

Heredity as constitutional contributor...... 53

Dises se and heredIty ............. 54

The nervous aystem and heredity ........ 5 ?

Nervous instabilsty in the animal. kingdon ...... 59

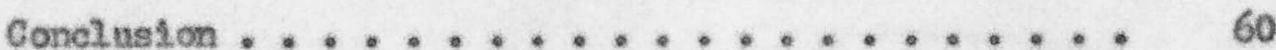

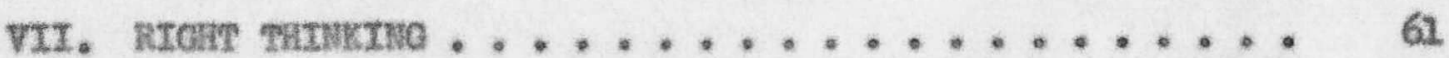

The phenononal fleld ............. 61

What is wrong with thinkingl .......... 62

Sources of rlght thoughts .......... 62

What can be done about wrong think ing? ........ 63 
Alds In dirocting the thinking. . . ............

Concluston.....................

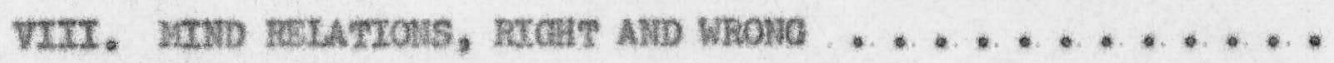

67

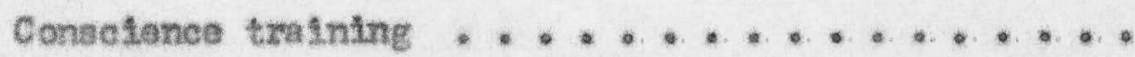

Influenca

Mass medta .........................

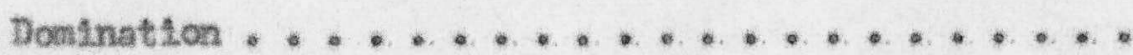

Drugs and the mind. .......................

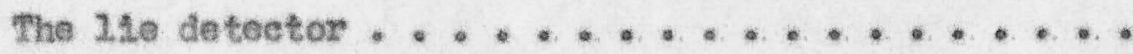

Hypnotian ........................

Bralnwashing ........................

complete mental freedor ....................

Parapsychology ,......................

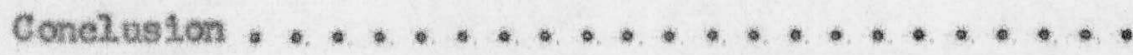

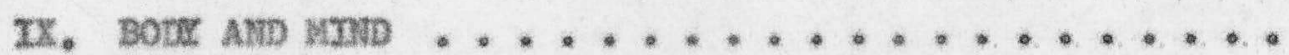

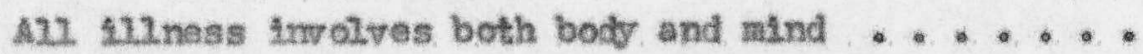

Chronte digease .....................

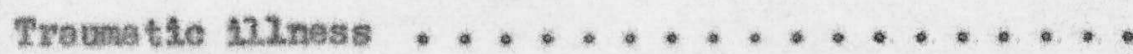


GนAPER

PACE

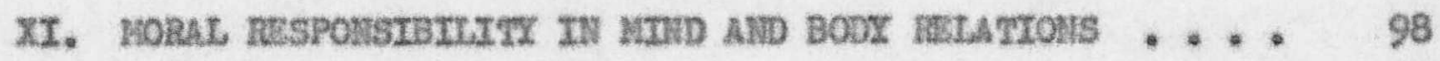
Difficulties in detemining moral responsibi21ty . . . 98 Indiv1dual dufferenees $\ldots \ldots \ldots$............... 98

Satan has a part in 211ness ............. 99

Status of moral responstbulsty ............. 200

Where responstbility begins $\ldots . . \ldots \ldots 2$

Conclustons ...................... 102

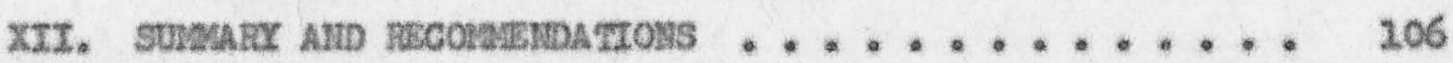

Sumany $\ldots \ldots \ldots \ldots . \ldots, \ldots$

Recommendations $\ldots \ldots \ldots 110$

BrmzоGMPLX ........................... 113

APFBNDIX A. Results of Benly Brrtronment ........... 119

APPEHDD B. Exglanation of Flgures .............. 122

AFPLIDIX C. Further Quotations from Nirs. White an Kind

Cure In Kedleal Practice............ 123 


\section{LISn of wovas}

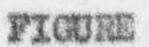

PACE

2. Effects of Tension $\ldots \ldots \ldots 22$

2. Plgure Inlustrating the Rffects of Norphine ....... 72

3. Figure Illugtrating the Effects of Atropine ...... 72

4. Figure Inistrating the Bffects of Caffelne ........ 73

5. Rorlex Areas of the Skin ................ 7ts 
CHAPTER I

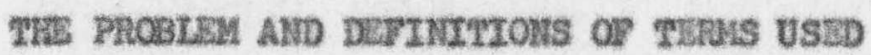

The idea of mind and body relationships is an old one. The statemont, "A sound mind in a sound boly," goes back to the ancient phllosophers, and even more aneiently the Bible stated, "As a man thinketh in his heart, so is he."nd. The modern concept provides new horlizons and new applications of mind and body ralationships.

\section{FHE PROBLEM}

Statenent of the prohien. The purpose of this study is to canpare the conel.ustons of nodern peychology and present-day medical understanding wisth what has been written by Mrs. Blien C. White on the subject of the rolation of wind and body. / Texts of Scripture and B1ble exarples w111. also be used. Hueh material, has cone into existence since the volumes of Mrs. White's writings appeared, yet the principles they portury are as up-to-date and as applicable as those in current 11terature. This author also points out warnings and dangers which apply to present prinoiples of psychalogy. Says Mrs. Whites

When Cod had wade man in His Imaga, the human form was porfect in all Its arrangements, but It was without 1ife. Then a personal. selif-existing God breathed into that form the breath of 21fe, and nan beeame a Iiving, intelligent being. All parts of the human organtem wers set in action. The heart, the arterles, the velns, the tongue, the hands, the feet, the senses, the facul.tles of the mand, ell began their work, and all were placed under Lawe ${ }^{2}$

\footnotetext{
IProwerbs $23: 7$.

2. refierred to as ME.)
} 
This is the law of nature, the law under whleh mind and body st111 operete.

Innortanee of the studt. The study of this subject is linportant becase "as we near the close of time, the human mind is more readuly affected by Satan's devices, "13 A study of this problem is also justifled as a part of Christian education. Hrs. White makes the following corenent:

True education means more than the pursual of a certain course of study. It means more than a preparation for the 219 that now is. It has to do with the whole being, and with the whole pertod of existence posstble to man. It is the hermonious deyelopnent of the physleal, the mentel, and the spiritual posers,

Also a study of mind and body is relevant to Christian education, as Is shown by the following statenent: "The students" employnent and anusenents should have been regulated w1th reference to phystcel. Lav, and should have been adapted to preserve to them the healthy tone of a21 the powers of body and mind."15

And as a climex for the reasons for stady Ing mind and body in Christian edueation, Mrs, White declares, ". . . the thoughts and feelIngs cambined make up the moral character." 6

3E21en G. White, Testinontes for the Church, I, 293. (Hereinaster referred to as $2 \mathrm{~L}, 5 \mathrm{~L}$, ete.. according to the respective valume number.)

Ba.)

4zMen $\mathrm{C}$. White, Idueation, po 33. (Hereinaf ter referred to as

$$
\text { Shate, 22, p. 242. Ghate, 5x, p. } 320 .
$$


Organization of the matorial. This thesis is bullt around the Idea of how the mind-body relatlonship invalves the physical make-up, the emotlons, and the learning and experience of the Individuel. The subjeot is introduced by calling attention to the difference sin has made on mind and boty: It shows how Jesus used both of these aspects In His healing of men, and ends with a discussion of Individual, responstbility for mind and body responses. The principles of psychology appear throughout the pages of Mrs. White's writings, and an understandIng of what is profitable snd what is unprofitable, a deternination of What is xight and also what is wronge appears in obvious ways and in mary places. So abundant is material. that it is imposetble to exhaust 1t in a single thesis. In mary places the use of tholy Scripture also 211.uninates the study.

More than the asual number of quotations appear in this study. However, this seens necessary in making such a conparison. Quotations froa many sources represent present-day concepts of psycholocy, whtle the other glde is necessarliy alone in Its contribution. Because of 2ts status and importance, It seems fitting to have it adeguately and accurately quoted. Then, whlle the other side has many sources, In order to do it justice It also seens necessary to support it with many first-hand statements.

Hatoxy and pasent statug. The ald-tine plysielen knew the background of his patients thoroughly, and assily recognized the infur once of exporience upon his patlents' 113nesses. Speolalization has loft wang such wen out of the present schone of things, and has replaced 
then with mediovi men with more eireunserlbed spec1alties. They aro much Less fanillar with tho montal make-up of thelr patients, but rev techniques of medicel diagnosis have been developed which have holped phy olelans to recognize the mental contribution of the patient to hi.s allsease. For some fifteen or twenty years the term "psychosonatie medicine" has boen froely used in modical Ifteraturo, and it is now so comanon that the laity has eaught the 1 dea also.

Source of date and wathod of procedure. This study has coverod a number of years. Host of the writinge of Mrs. Blien C. White have beon read whth this topte In mind. Several courses in psychologg have contributed to 1ts development, and coneurrentisy reading of psychological. Ilters ture has proceeded. Large numbers of notes have been taken, and ali of these hove been slfted for rolevant materiel.

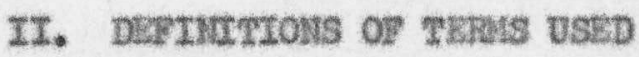

Ueltings of Wos. White. The writings of Mrs. Bilen C. White form an Important part of the denoninational ilterature of the Serenthday Adventist Chureh because 1ts mambers believe them to be inspired. These writings are not a second BLble, but only a lesser light to guide to the greater 1ight, the Iloly Seriptures.

Bszchosonatie. The terai "psychosomatio" is derivod fron two Croek woxds, Druche, mind, and some, body. It means a combination of mind and body in physteal disabilitles. 
Eunctionel disease. The nanifostation is functional rathey than organie. That 1s, thore are no al terations in body thasuo, but rather: dasturuance of an orgen's activities.

Nourosts. A neurosis is the sane as a psychosconatio or funethonal disease. Sonotimes the term "prychonourosis" is also used, and It bas the same meaning.

The antonortic nexsens systen. The involuntary norves supply ing the visceral organe of the body are known as the autononic nervous systen. Obriously the autononie norves are not under the control of the พมบเ

The saroathatie divistion of the autononte swatem. This part of the system speeds up reactions and propares the body to neet anergoneles. The digestive processes, however, are inhibited, so that the onergles used in digestion are ava2lable for inereased activity elsewhere.

The paravanathetle divitalon of the antononie suatem. The second divistion of the sutononte system keeps the body functianing saoothiy, and brings about restoration after an emergency has upset the balanco. If overiy aroused, however, it shows Its a ctivity particularly on the digestive systen.

The endoceine sratom. The endoerine systen conststs of glands 12ke the thyrold and adrenals which heve no duots, but give up their secrotion to the blood strean as 1t passes through them. They are also known as duotless clands. 
The exoorine glands. The exocrine glands as duct glands poux their secrotion out through tiry ducts to tho external surituco. Tho selivary glands and the tear glende are examples of exocrine elands.

Enation. Linotion is handied by the sutcononte nowvous system along with certain aross in the bratn. Emotion inoludes ax feeling tones* 


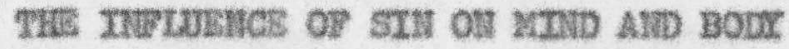

The study of mind and boty can well begth with the entrance of sin. BLzen Q. Whate ranarks: When Adan and Eve were placed in the besuthru2 garden, they had everything for their happlness which they could destre, en A survey of the changes Introluced by sin shows up prominently the background for mind and body relationships as they have sunce developed in the husan race.

\section{BEctunzwos}

Cenesis is a book of beginatings. Wot onily, "In the beginning Cod ereated," but under the tree of lnowledge of good and ovi2, sin and misoxy, pain and death had their begining as well. The fixat tempta-

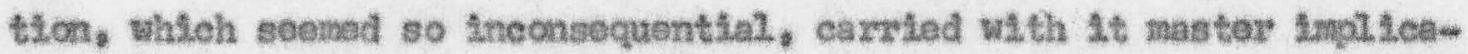
thons for enornous evil. Involvements were widespread. Iro a te the Prutt: she shared 1.t wtth Adam. They had distrusted God, they had yielded to appetite, thcy had Investigated knowledge Cod wished withelis. Thelr hapginess and poace were gone, they had mlsused thelr powor of

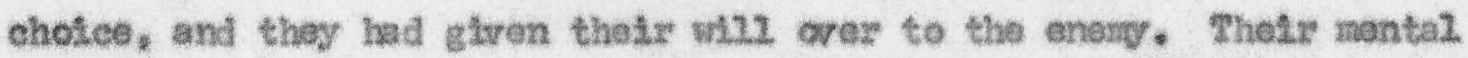
and plvsteal capacities wore not only roduced but changed, by ano seentngly small disobodience. Mrs. White doelares:

After his tranegression, Adan at Irst Lugined hinself entering upon a highex state of exlstenoe. But soon the thought of hls sin

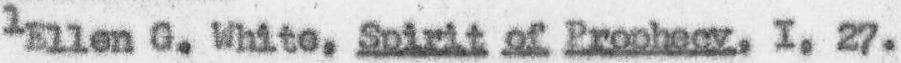


funled bin with terros. The alr, which had hitherto boen of a ndid and uniform temperature, soened to chin the gull ty paix. The $20 v e$ and paee whtoh had been thoxire was gone, and in Its place they folt a eonse of sin, a dread of the future, a nakedness of sovi.. ${ }^{2}$

II. The Loss of con's PREstuse

The Importance of 1 ove In the life has recelvad considerable coment in current 21tersture. In Snlley Blanton"s book, Lore ex Rexish. there is an Introduction written by another porson who is unnamed. Ne remarks:

In simple, direct language he has shown hov lore is the vital force, the essential ingredient, that binds us together and makes of our overy act a nov, rich and exclting exporionce.

Whthout Lore--in every form-the collapse of Life begtns. Fron the simple arudgoxy of gotting up in the morning to the almost incredible disasters that lead into death 1 tsele, there 1.8 , clear evidence that no man or waman can hope to survive in a life gutdod by hatrod, The alternatives are, indeed, "Love or Pertsh" "

Por without Lore, we lose the vilu to IIve. Our montal and plysieal vitality is Impalred, our rosistaneg is lowerod, and wo succurab to t1inesses that often prove fatal. 3

The gaty ty paIr, Adan and Ive, had saparated thenselves from Cod"s companionship, They had pushed His lore out of their lmaediate exper1ence. They had violeted theis relationship to $2 t$. In the aet of restoratlon, "God so 2ored the world, that He gave His only begotton Son, that Whosoover believeth on IIn shonld nat nerish." "4

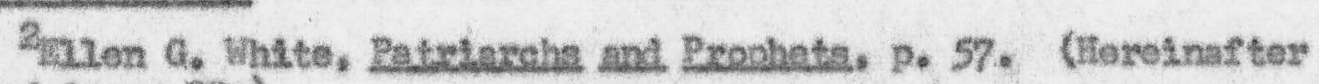
retersed to as $\mathrm{ED}$.)

3 Smliey Blanton, Lore ox Rexish, Introduction on cover of the paperbound editton.

4Joln 3:26. (Xtalies supplied.) 


\section{ITI, HOM DISTASE OZTONHATS}

When evening cane on the day of the fa2l, bringing the time for Coits dally visit-the last one-midam and Bve hid thenselves. Already the canses wero oporating that would Iead to mental and plysteal. sufforing. Seys Mrs, White:

Many of the dissases fron which men suffer are the wesuld of mental. depression. GrL̈of, arnclety, diseontent, Fenorse, guilt, distrust, ali. tend to break down the 1ife foress, and to invite decay and daath. 5

Three main causes of disease found thelr ortgin on that unhapy day in Eden:

1. Those whteh artse frow wrong eating.

2. Those that have thoir souree In mind and body relatlonshtps.

3. Those which result in physical degenerecy,

The cause of Adan's death is not recorted. His years of montal surferIng must bave contributed to a death which was obvionsiy degenerative.

Those three eanges of disease are interralated. mine-tenths of diseases trom whith nen suffer," says Mrs, Mhtto, "have tholr foundation here [in the mind]. ${ }^{\text {6 }}$ "The Indulgence of unnatural appotites. . . has a earitrolling influence upon the nerves of the brain,"7 "Irregularittes In eating destro the healthrul tone of the digestive organs, to the

\section{Whate, un, D. 242.}

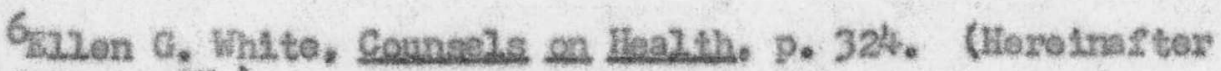
raforred to as Git.)

7 Mad. p. 36. 
detrinent of health and cheerfulnoes, "w "Wrong habits of eating and the use of unhesltherl food are in no small. degree responstble for the intanperance and cxtwo and wretehedness that curse the world." "In all ages, temptatlons appealing to the plysleal nature have boen most effectual in comsupting and degreding mankind. "lo llot oniy the three causes of disease are related, but the transgression of the plystoal Iawe 1 also involved in tho morel and spiritual aspects of man's noturo. On this, Hrs, Whto ronarkst

The bocty is the only medium through which the aind and tho soul are developed for the upbutlling of character. Hence it is that the adversary of soule diroets his temptations to the enteebling and dograding of the physleal powors. His succoss hore moans tho surxender to evil of the whole baing. The tendencles of our plysical. neture, uniess undey the dominion of a highez pover, wiา suroly work ruin and death. II

\section{TEE PATISEU of nesTozarton}

In the begiming God ereated; in ths beginning sin and death entered. Just as from thet evil day in Eden man bogan to foel. death through the powox of appetite and through the brealedoun of the enotlons, In restoration Christ gained the vietory orer appetite, and felt the estrone of esotion $2 \mathrm{n}$ HIe strugele with sin.

With Clurist, as with the haly palx in Bden, appetite was the ground of the sliset great temptation. Just where the zruln began,

\section{Bhate, yt, p. 384. 97nat. p. 146.}

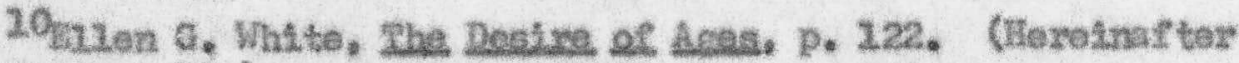
referred to as DL.)

21. White, vel, p. 230 , 
the work of our roderption mast begin. As by Indulgence of appeth te Adam fell, so by the denial of appetite Christ must orereane. 12

The cross constituted the ellimax of Chrlst's suffering, but there wore other tines when Bis suffering vas extreno. One was His expertence In the whldemess when Ho overcane the terptatlons of appetite and presunptlon, whon lle rofused the easy vay Satan suggested to regain the woxld in one sirale act of honage to the one who clatmed the right to Lte soverelentr.

Wrs. White thus deseribes Christ's expertences

After the foe had depazted, Jesus fell exchausted to the earth, whth the pailor of doath upon His face. The angols of hoavon had we tehsd the conflict, beholding thelr Iored Consander as He passed through inexpresstble suffering to make a way of escape for us. Ho had endured the test, greater than wo shall ever be ealied to ondure. The angels now minlstored to the Son of Cod, as Ho 2 ay like one dying. 13

When on the eross the penalty was paid at Last, Christ diod a prychosonatie death. Ho died fron a broken hasrt, broken with the agontes and gurzt of sin. When Adam sopazuted himself fron Cod's Imadiate presence, he stinz had sccess direotly to Hin. Whon Christ on the cross was acparated from Cod by the sins of the world, the separstion soenod eomplete. In that dark hour He oried, "ry God, $1 \mathrm{y}$ God, why hast thou forsaken magnit The sacriflesal lamb died a trauastie death, but Christ shed His blood for the guilt of a falien world, Hie paseed through tho suporlative of sufrering. Ho was na Man

$$
\begin{aligned}
& \text { 12, whate, 24, p. 117. 13 Mnta., p. } 131 . \\
& \text { 14hat thew } 27: 46 .
\end{aligned}
$$


of somroms, and acquelnted with grief" al1. through His 1Afo, and on tho cross "lie boro ous grlats, and carried our sorrows, w15 This was an angutsh beyond human expertence.

\section{V. concLostom}

Sin brought ehanges in the plyeteal nature. Crief, gutlt, anxiety, depressicn became the fruitrul potentialities thet oventualiy produced disoase. Such mantel InR uonces now appoer in all LIInesses and prodoninate in a Long 2 ist of precent-day disorders. Dating, which was smolved in the original sin, is closely related to the mind. Whon Christ earne in the Mosh to rodeen man, Ho began whore sin began by resisting appotite. Ho suffored as man had suffored with erief, extrene mental surforing, and whth vicarious gutit. He rostored the love relationship between Cod and man. He Lored the worid and would not let It portish.

15 Isalah 53:3, 4 . 
To understand the relation of nind and body. the physteel wake-up needs to be studied as well as tho prychol.ogteal. This partientarly Includes the nervous and endoertne systems. silen 0 . White doclares. "As the mechanism of the body is studied, attentzon should be direeted to 2 ts wonderful adeptation of means to ends, the hamonious action and dopendenee of various organs,

\section{Imortwasics of mystotocx}

Paychalogy represents the lave of the mind fran the standpoint of 1 te Intellectual and enotIonel functzoning, but anetomy and plystalory are necessary subjects to complete the undergtanding of mind and body combination. The Christian goes evon deoper in his understanding of this prtnotple. Wle realzzss thst "the Laws thst gorern our plystcal organtsm, God hag written upon evory nezve, auscle, and ether of the body. 2

In 1903, when tho book Edneatson was wrttten, there was not the Iood of prychoscratie 12terature that now excists. but the study of phystalog was emphasteed beesuse 1t explains the InRLunee of mind on body. The electric power of the brain had not then been diacorered by

$$
\begin{aligned}
& \text { Zhite, Edas p. 198. } \\
& \text { 2motd.: pp. 196-97. }
\end{aligned}
$$


plystelogtate, but it is recognised in this book as a part of the function of the norvous systen, and It is now diseussed in textbooks on anctary and phystalog.

Nrs. Whito states on this important intorrolationehip:

The Inrzuonee of the mind on the body, se well as of the body on the mind, showld be emplasized. The eleetric pover of tho bratn, pronotod by mental activity, vitalizes the whole systom, and is thus an Irwaluble ald in resisting disease. This should bo made plain. The powor of the wIII and the importance of self-control. both in tho preservation and in the rocovery of hoalth, the depressIng and even rulnous effect of anger, discontent, selfishnoss, or impurtty, and, on the othor hand, the marvelous ilfe-giving power to be found In cheorfulness, unselfishness, cretitude, ehould aleo be shown.

There is a plystalogieal truth-mruth that we need to considerIn the Serfpture, "A marry [rojolcing] hoset dooth good 2ilke a redacoine."13

\section{DEDERTrna PranctPLES}

Bess Curntingham spprosohes her treatment of alind and body rolationshipe by stating three undezlyting prinetples:

1. "Ho bohavior is haphazard." That $2 s$, behevios is an orderly, dopendable reaponse to stimuri.

2. "Behavior is not fragnentaxy," The whole organtsan responds.

3. Wue react to total sltuatlons," Not oniy the whole organism responds, but $2 t$ responds to the total situation. ${ }^{4}$

Shtto, EA, p. 197.

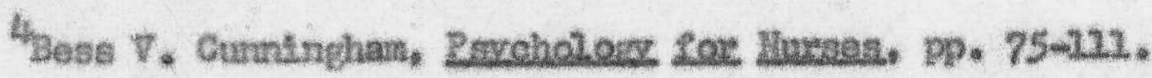


IT., Przstcat, voctuntsas

Tho nervous systam conststs, geographtealyy, of tho contral. norvous systan and the peripheral. nervous systen, The braln and spinal. cord aro constdered to be tho central nervous systen, and the nerve extenesons which go cut to the various parts of the body congrise the poriphoxal nexvous syston. Funetionaliy thoy aust bo divided a Iittle differently-woluntary and Involuntayy. The poriphewal norves aro of both kinds.

If the peripheral nerves go to the internal organs which aro not under the contral of the w222, thoy operate imvaluntarizy. of 1 f they supply the external parts when they may be conselously control:ed, they sre valuntary. The imvoluntary division is variousiy terned viscers1, sympathetle, splenohnie, or autononic. "Autonomis" has becons the woxd which Is used most often in professions2. 12terature and is froquently scen in other writing. This is the port of the nexvous Eyeten most coneerned with the body-end-mind funotional cabination. Of couree the mind itself functions in the roletion, partievierly the lypotholame, which contains the emotional conters, and the cerebrel. cortex, which supplies conscious reeognition to enotion. Howover, wuch function lis completely unconselous.

There are two divistons to this system, the sympathetic and the paresympathetle. Fibers erom each of these two ports supply proctically all of the vieceral organs as weli as such extemnl parts as the sweat glands, the tiry arsetor muscles conmeeted with the hatr follicles, and 
the elltary, or accomadation, musele of the eye. Unilike the sensory and motor nexves, of which the sensury nerves go to the brain snd the motor norves come fron the brain to the part served, the two divisions of the autonomice system both go to the organ. On the whole, the sympethetie division accelerates a function, and the parasyngathetie tends to keep the systen running smoothly and norrally. The sympathetie nerves have their origin in ganglia distributed along the outside of the vertebree, with the preganglionie flbers extending into the spinal cord, and the postganglionic 1 ibers reaching out to the various organs. The parasympthetic or eranio-sacral division has its origin In the brain, with other fibers arising outside the sacral part of the spinal calum. Of the twelve exanial nerves, the third, the seventh, the ninth, the tenth, and the elevonth all carry parasymathetie rlbers as well. as sensory and motor, or motor stbers alone.

These two sets of nerves have control. of all of the involuntaxy functions of the body, such as the moresent of Internal organs, and the secrotions of the glands. They are very sensitive to the external. conditions under which the body operetes. While they function as a unit, they are not entirely Independent of other parts of the narvous system.

Our thinking results in a total body response through the activity of these nerves, so that in truth, men thinks with his bones, skin, blood, and in fact with every organ of the body. The entire bodily funetions respond constently to the emotional tone of thinking. Under strong emotion, 14ke Iright, the autononle systen sets up an emergency resction. The sympathetic funetions predonina te over the 
parasymathet2c. The pup1ls dilate, the respiratory rate Increases, the heart action is accelereted, the clrculation is speeded up, and the Ifres pours nore elueose Into the blood strean. The digestive perts of the organtsm are Inhlbited, end thus turn orey extra blood and energy to the ports of the body where it is needed for activity in noeting the emorgency.

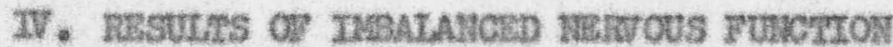

Stagner gives sone Important facts about the results of imbalaneed nervous funetlon:

Ressantress $2 \mathrm{~s}$ often, al thouph not alvays, reluted to activity of the persanapathetic (cranto-sacra2) diviston of the autononie, the section which speeds up digestion, slows down the hoart rate, and

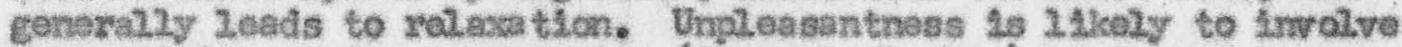
the activity of tho sympathetic (thoracic-lurbar) rogton of the antononte, whiteh accelerates the heert, ratses the blood pressure, shunts digestion astde, and generrally preperses for violent action. Excitement, whether in a context of pleasant on of urploasant fealing, is acsociated with the pirviologieal affects listed for umpleasantnoss. The visceral, pteture in the case of depresston is confused. ...

It hes lang been lenown, for exanple, that porsoral maledjustnent Is ofton assoclated with the oceurrence of stonach vilcers. This can bo related to the effect of prolonged excltenent and unpleasent feeling upen the digestive processes. Kaler and Parkoz (1945) found that even rats w111 develog storach inflerenations from ropeated exposuro elther to mpleasant audt tory etimulis or to a

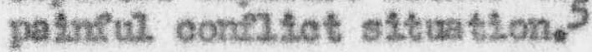

A pleture of nervous Inbelance is given by Mrs. Whate as follons:

When the alnds of miniaters, sehool. teachers, and students are continualiy exclted by atudy, and the body is ailowed to be inactive, the nerves of enotion are tassed, while the neswes of motion are

Shoss stames, Rexchaloor of Rowsonaltty, pp, 85-36. 
Inective. The wear being all upon the mental orcans, thoy become

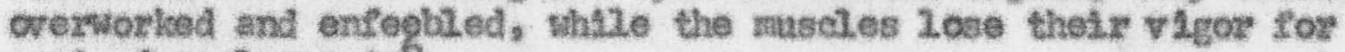
want of employment.

Hero is an inbalaneo between the central, or voluntary norvous system and the autononte or involuntary system showang up in rosults that are both mental, and physical. Fran these guotations it 2e easy to see that disturbanco between two parts of the autanoule nervous systen, or between the contral and the autononte nervous systens, upsets functhon, and If such condttlons last Iong enough or are froguent enough, bodily function could be so disturbed as to produce disease.

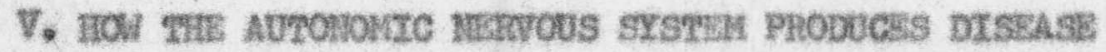

Dr. Harold Shyyoek asks the question, " py what mesns can the eutononto nervous system produce disease?" The following are his conclustons about these moans as workod out from a Cemen author, Leopord Aukams

The (1) snooth muscles and (2) glands of the body are enervated by norve rtbors of the sutonomie nervous aysten which, in turn, is controlled from the sams regton of the brein (hypothalasne) as provides for the emotional. respanses of the orgenism, . . .

2. Persistent eontraction of the eircular smooth muecle in the wall of a hollou organ produelres a relative anomia of the reglon with ccrseguent laek of nutrition. Thts is ons proposod explanaton of the cause of peptie theer, wleeratire colitis, ete.

2. Persistent or recurront spasm of the smooth muscle of tubulas orrons leading to hypertrophy of the muscle with secondary dulatation, as in aliatation of the esophasus or hyportrophy of the left ventricle in essential wportonsion,

Gh2te, 32, p. 4po. 
3. Persistent or recurrent spasa of the smooth wuscle of a twbular organ protucing stasls of the fnulds which normaliy pase through the organ es in cholesterol. stone of the gall bladder or congastive esophagittes.

4. Persistent spasm of the saooth muscle in tho wall of a tubular organ produoins such stasis, unter pressure, of the contents of the organ as to ftwor the development of an Infectlous process as ceses of infection oceurrint in gall. bladder obstruction.

Camoron amplifies these statenents in the fallowing wey:

WLsceral tengtons and glandular activity, once axoused, axe very 14kely to parsist and to spread wi thout furthos stimulation. This Is begatue snooth musele is normaliy al ou to contrect, slewer sti11 to relax, and capable of ma intaining a state of tonglon vith 21tt2e fatigua. It is beeause the distribution of smooth nuscile, as for oxample In the vast blood-ressel notwork, is prectically cooxtansive with the body 1tself. Finaliy it is becsuse glandulas socrotions alrovlate unt21. broken doun ox excretad, and because they act both upon the autononte norvous system, and diregtiy back upon the glanis, to continue thetr oun secrotary activities."

These quotations deseribe the mechanian of peychoscrutice disease, and 24 should be elear that the mind-body dichotony in functional dfsease produces actual, not Ineglnary, symptons, and that there is demenstrable pathology present in scme of then. Nary people who glibly use the vernaculay terminology, "It is aly in the haad," are unataxe of the tact that such disease Is actual, but caused by the exotions and not by meroly thinking that one is slek. Bmotions are cominon equipnent given ly the Creator to all bumankind; therefore, aul are subject to psychosonstie disedse. There are individual differences in potentiality due to various factors, but novertheless there are univereal possibiuttes.

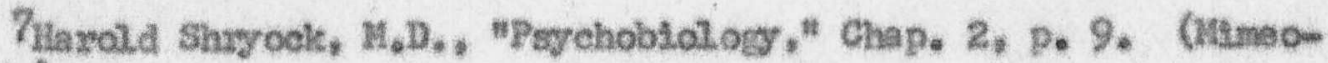
eraphed.)

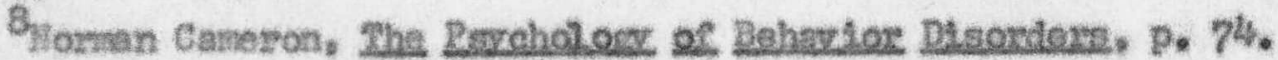


Wary enothomal expertenees are beyond the control of the Individual, or are even nowe Intense than he $1 \mathrm{~s}$ able to handle.

Walf and libles were able to observe a man whth a gactrostory over a porlod of months. They found that when the ran experienoed sudden. Iear, the walls of his stomeh peled, but with aruxtety the mucose reddenad. If the arotety continued, snall. henotrhaces developed and the formation of mucus falled, so that acad affected the thssues. Thts pheture conforms to the faet that foar acte to dilate the pusl2s, dilate the bronchial. tubes, quicken the heart beat, Inerease tho roleace of elyeogen fron the 2iver, and check tho secretton of glands and the process of digestlon. The elrculatton to the dLgestlve argans is deprossed, and the blood usually nomal, to these aroes le diseotod to

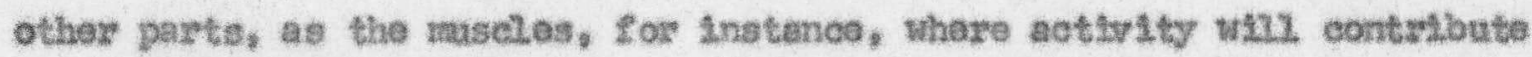
to salety. On the othor hand, aroxiety showed ap objeotively in an oxcessive supply of blood to the stomach.?

Dr. Nans Selve of Nontroal has done sone extensLve work wth wh1te 1 tats on what he calis the "adeptatLon syndrorre, He subjeets. thoge 21 ttle antual.s to vartous forms of frustration, and at the heleht of the ronetton k:118 thern and exanthes the Ix organs. He found that not only the stonach, but the whole viscere rasponded to such stimul. WIs antma? flndings corresponded to the findings of the doctors on the

9xthur W. Jay, "Is It IndLgestion?" Amoricsn Journal of Jure-

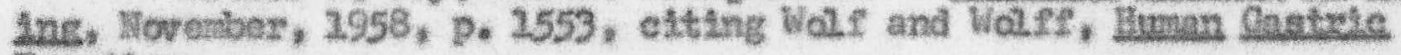
Enerctyors. 
luman subject, and fumishod sven greater inclusivoness, as ho could exasine the whole visceral, content. ${ }^{20}$

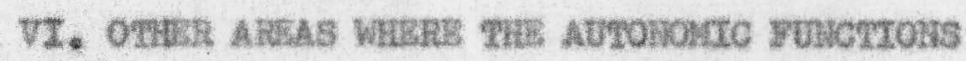

There are other areas where the mind and body funotion as a unit. The 2 ise detector uses changes due to nerve eomectlons to interpret truthfulness. Its gadgets mes eure hlood pressure, changes in resplrathon, pulse rate and sldin moletrave to doteet emotional changes in the Indivitual. Those ehonges witoh develop during questioning intorpret emotional response. A Large number of medicstions depend upon vartous parts of the narvous systen for theIr ourative affects. When a dentist uses hymotism to oxtract a tooth without pain, ho is usine tho autononlo norvous systen. Sone of the mirveulious heal ing seen in these thmos also has 1ts succoss beoause of the sction of the autononio nervous astan. 21.

\section{NRS, WITIS OH AUTONOUIC ACrrol}

Described as aceurately as in modem modical ziterature is the sctirity of the sutonoulle nowrous systan as found in the writings of Ezien $\mathrm{G}$. White. Kres, Mhite declares:

The norves procseding Iron the brain contral the body. Dy the brein noxves, nental. Improsstons are convoyed to all the nerves

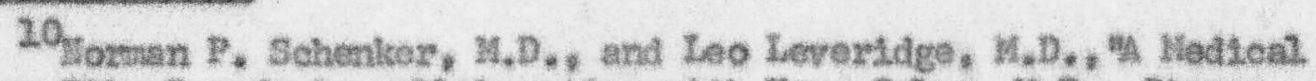

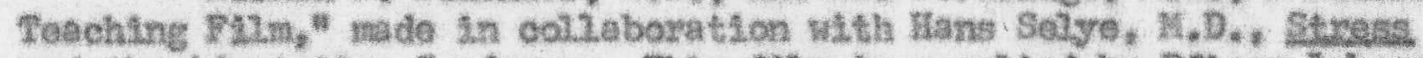

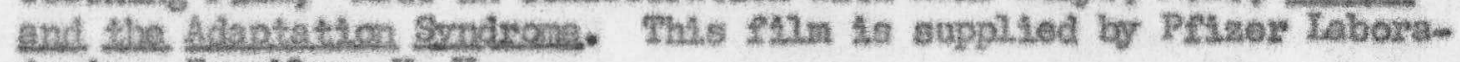
tories, Brookyn, H. $_{*}$.

$$
11 \text { See } 12.5 .2,0.22 .
$$


Anxiety

Worry

Fear

Remorse

Distrust

Overconscientiousn

Mental conditioning reflex sig

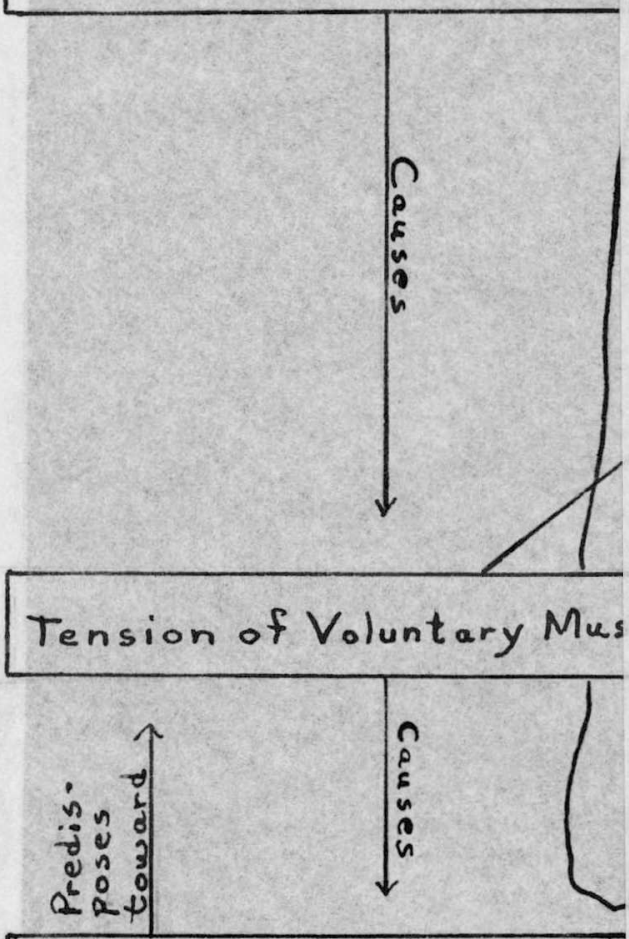

Low Reserve Energy

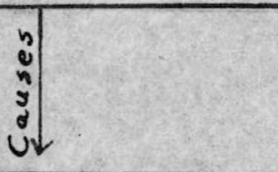

Physical disease

Thyroid disturbance Influenza

Chronic infections

Anemia, aging, pregna. Malnutrition
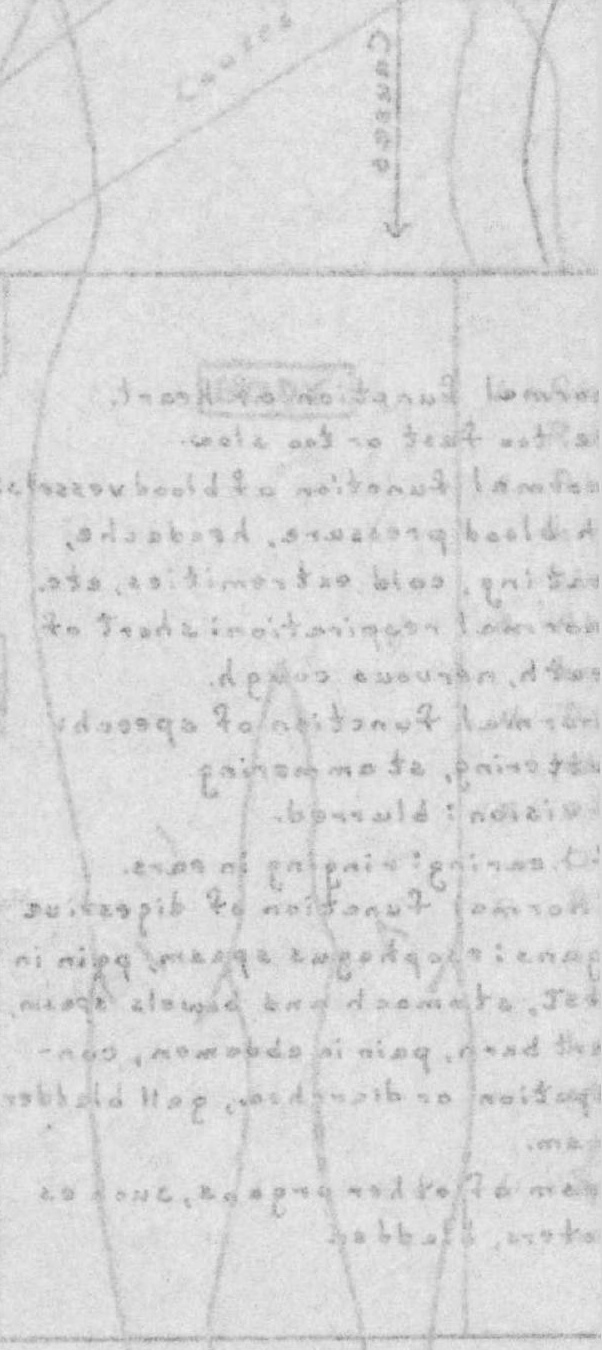
of the body as by telegraph whes: and thay control. the vital, action of every port of the systent. AII the organs of mothon are goremed by the conmunteations they recotve fron the brein.

If your mind is trmprosed and flued that a beth why Injure you, the mental Impreseton is connumicated to all the nerves of the body. The norves contral the eireuletton of the blood; therefore the blood $1 \mathrm{~s}$, through the Improsston of the alnd, canfined to the blood-rossels, and the good effects of the bath aro lost. A27 this is because the blood ts prevented by the atind and vily. fron Roulng readity, and fron ooming to the surface to stimulate, axousc, and promote the cireulation. For instance, you are inprossed that if you bathe, you wi1z becone ohd17y. The bratin sends this intelliganee to the nerves of the boty, and the blood-

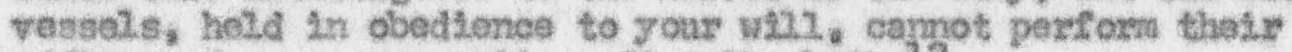
offlce and cause a reaction after the bath. 12

The cireulation of the blood is a funotion of the autonomie arstem whieh also indireatiy controls the hoart, and direotly, the Alzation and constriation of tho blood vessels.

In order to have good heal th, we must have good blood: for the biood is the current of 14fe. It repairs weste, and nowrishes the body. When supplied with the proper food elenents and when cleansed and vital 2 sod by contact with pure alr, it carrios Ilfe and vigor to evary part of the grstem, The more perfect the olroulation, the better will this worls be accoraplished. 13

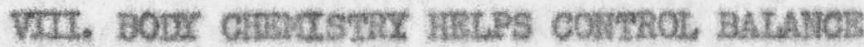

The basts for balance in the body 1 les partiy in the cherdeal. supply to the boty. Tha autonomitic narves, according to tho nexarohumoral theory; assuns the manutacture of chemicals at the mynapses and myronoural junctions. A17. parasympathette and preganglionle aympathetio flbers are cleostrted as cholinergic, and the syngathotle, escept those golng to the sweat glends, the artericles of the rauseles and the

$$
\text { 12.mate, 25, pp; 69-70, 13hate, 28, p. } 272 \text {. }
$$


uterus, aro adrenorgle, on adrenalin produoing. Whenever cholinergte

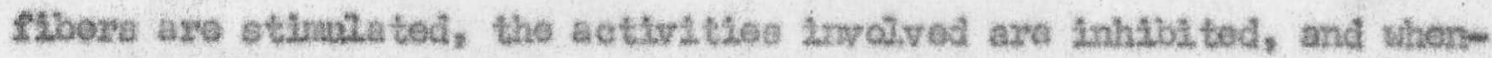
eves adrenergic stbers are stimulatod, they bring about accelerathon. ${ }^{2 / 4}$ Anothere source of body chenlstry is the glands. Tho andogrine elands have a most direet effect, because they pour the Ir chenteals direotiy lnto the blood streain, The exoorine clands are nostly in the Algestiva system, on In the case of the swast glands and sabaceous glends, in the sicin. These glands are nore Indirect in the results of that frunetlon.

The endocrire elands have waoh to do wth wall-belng direotly, as they Influence function and feel. Ings of well-being or discaufout. As they changs the appearance and make the Indiv Ldusl consplenous os a misftit, they contribute to unhspginess, Infortority feelings, and malad justrent.

A Large golter is unsightiy and maks its omex feal, ocnspicuous.

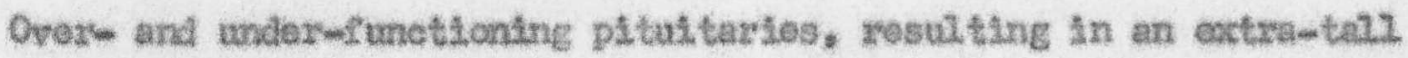

24 The nexre inpulse Itself, according to the present theory, takes place by a process of fepolerizatlon. During tranemisston, positive charges change to negative and are Imadiately restored to posative as the impulse progresses along its route. The axeas there the nerves comnect whth other nerves aro known as synspess. The endings teminoting in muscle tissue are nyroneural junctions. At the symapees narve Iibers do not make actual contact with the next norve to which the impulse passes in the ronex arc. Transulesion of nexve Impuleos across these syrapses is accounted for by two no in theories-o the nouro-humeral, and the eloetric. The neurombunorul assumes thst chantcals stirnalate the nerve endings to continue the Lapulse. AecondIng to the eleetrical. thoory, an electrieal stinulation carries the limpul.so across. "Much evidonce has accumulated in support of both electritcal and chemical theorles. . . . It nay well be that thoy are

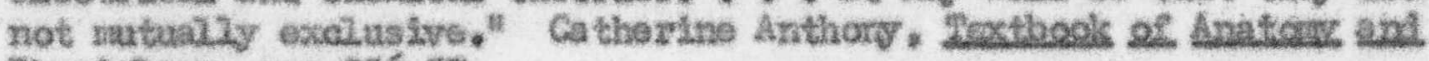

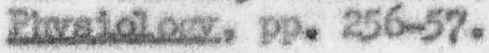


porson or one who is too sal2l, blso effect the porsonelity. When too much thyrold secrettica is being poured into the blood strean, nervousnoss w11 result. These are onily a fou facets of adjustment as 1 t 18 bound up with the endocrine arstem,

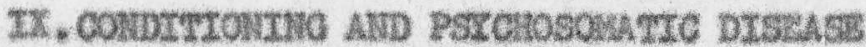

Another situation resulting 2 in psyehosonatie disease has Ats ordgin in conditioning. It is posstble to lay down patterns in the nervous cyatem that make for maladjustronts and oven disease. A child ewalcens In the moming with nausea. He vontts, and it is evident that ho camnot go to school. The cheld is glad to stay at hono and be teken care of by his mother. Six woalcs $2 a$ ter ho droadis to go to sohocl. because he must tace the tesoher about somo dolinquent assignnent. The nervous aston canos to his reseue whth the former pattem of escape. The dread turns Into falntness, neuses, and perhaps a hoadache. This, of course, Is unplanned sad entlrely uneonselous, but the boty has learned a way to respond to unpleasant sttuations by fooling 212. This condltioning is after the same foshion as that of Pavlori's doga who Learnod to salivate at the sound of a bell.

Durarg World Mar II a saLlor servod In the San DLogo area. It was poss2ble for hin to malntain a hono and stul, poxforn his nulitary dutles, so his wife fallowed hin fron their hane in the Mltwest. Whenever It becane evilent that the sanoz might be shipped out, the wife becare 211. Thmo after timo he sesmod about to be put on the 21st to go across, and with each prospective, the wife becane 211 fron one 
cause or another. Sonotines It was sano algestive trouble, symptone that pointed to gall bladdor difrloulty, one timo 14 was a kidney Intection that produced symptoas out of all camparison with what the pothology reprosented, and the last timo 1 t was pernlolous vordting acconganied by groat prostre tion and disorlentation. This wonan was given every medieal attentLon, SLrat in a good private hospltal, and thon In the Noval. hospltal. Final2y tho Navg alived the problen by aLschareing her husband. They zeturned to thoLy Madvest hono, and no doubt her health 14kewise retumed. Such pattems are sot up in childhood. Thoy roprosent the Indir Idual's adjustment to dier2oult problens, and aro a produet of eonditioning.

The var nouroses surfered by sone soldieses wore allnont adjustmonts. The problen, too big or too painful, for the men, cane out In a plysteal eandition that solved the problem for then, The porson we actually bilnd or peralyzed. The minl, without his coneclous consent, had morcifwily blocked out resgonses to that was beyond his capaeity to handlo. These men were not eoraxds, but they neoded psychlatrite help to solve thetr problens.

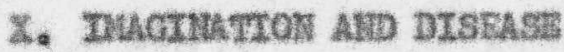

Ltthe disoses of mind and body is malingoxing, and oven thaglnaxy ALisease constltutes a sall port. DLsease has Its ortgin in the emot2ons nore often than in the Inagination, but the Iraglnatlion cen produce disease that is real. 
Disesso is sonatines produced, and Is often grootly agerevated,

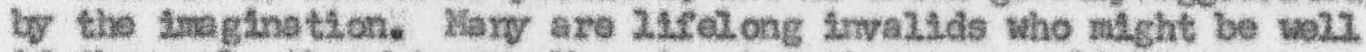
12 they oniy thought so. Nary langino that overy allicht exposure will cause Liness, snd the ovil effect is produced becouse it is expectod. Hary dise from discase, the eause of whieh is wholly insegtnaxy. 15

Heze, the person lets his lnaginatlen go wild with fear. Sane-

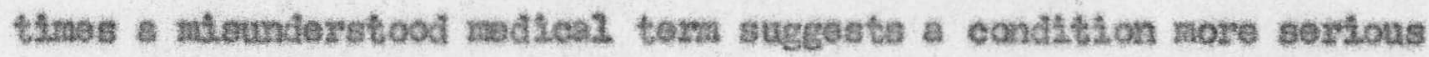
than actually extsts. Sonetimes one has a long lilnesa and develope more care-taking of hinsele than is callod for, and fron fear of taking chances, leops on boing an irrallid. Whether the allment is from emotional stress, an allnont adjustmont due to conditioning, or an Inaginary eondition, the autononle norvous system acts in about the same way.

\section{x. coscustos}

Both pgychalogy and plysiology are necesany in understanding the nitnd and body relatlonship. The brain is the eapital of the body. Its oxtensions, In the form of nerves, roach all parte. This arrangensnt provides for a total and consistent response to all stimul. The autonomle nervous systen plus the endocrine system are partloularly concerned with this control and constancy of boly functions. The autonomite opervtes in close connection with the anotzonal centers in the brain, and this explatne the elose relation between the enotions and functional disease. 


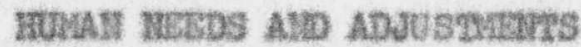

Health, both montal and phrsicel, is the resuits of satisfted needs. Wuch can happen between the time a need is made ovident and the tine 2t has been satrafled. Hurnen bohavior fizla this gap.

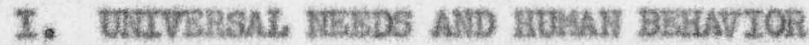

Tho human bodty constantiy maintains a state of equizibriam within cortain wather fluced 1 Inits. This is known as homaostasis, and Lt moane that 12 terperature ranges abore or belos a certain number of dogroes, the body doos not survives if the blood eoll count exreeeds or

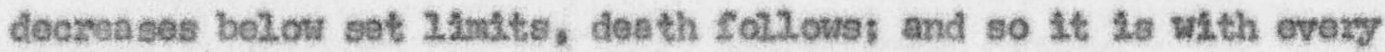
bodtzy condation. ${ }^{2}$ Any excess or dertetency is expressed in a noed, a need Irunodiatoly sets up teneion, whloh provokes activity or drive, which lests unt2i sone sort of adjustmant relleves the tenslon, stops the activ1ty, satisfias the neec, and has achleyed sone sort of adjutstnont, be 1t adequate or inadeguate.

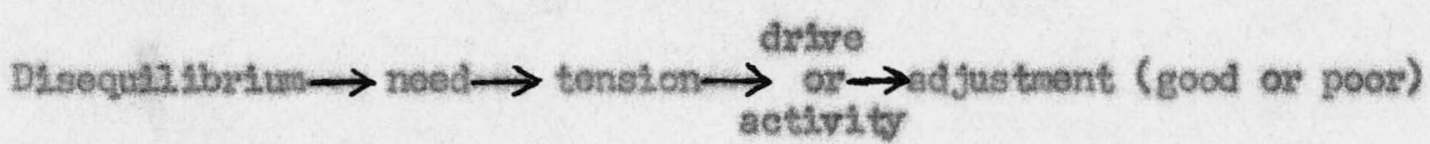

Settafactory Livine dopends upon the fuleulument of certain baslo needs, sonotines referred to as universal needs. These aro

2The husan body is very adjuateble, and sonetines the lindts of theoretlenl. honeostasis are exceeded with survival. 
Iisted in varions ways by different authors. Bess Cumingham glves then as "a need to be sale and enothonally secure, a need for approval, Love and affection, a noed to belong, and a need to prove . . porsomi.

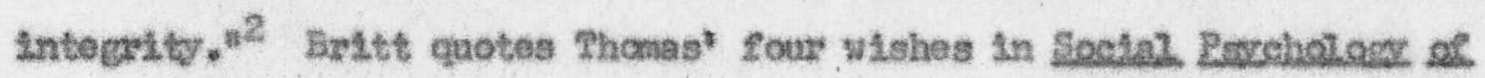
Nodern Lifes (1) for now experiences; (2) for seeurdty! (3) for rosponses (4) for recognition? Syrands, quoting fron 4 Theory of Luman Lotivation by A, H, Hasiow, 1.1sts the following as Naslow's hiersarcly: There are first level or basle plysialogieal noeds, thon the second level or a need for safoty, the third level or the need for 1ove, the fourth leval or the noed for self-esteen, and the fifth level. or tho meed fos self-realizstion. Symonds adds:

The hoalthy man is one whose basle neede heve been mot se thst he is prinotpal2y wotivated by his needs to develop and actualize his highest potentlalities. The noladjusted and neusotic person, on the other hand, Is one tho is dominated by his more basie needs. Since hls provious insecurdties have never mede him fecl entirely sate with regard to gretiflestion of his nove besio noeds, he is nover culte fres to turn hls ${ }_{4}$ attention to activities of selfroallasation and achlovenent.

These noeds and their fulswluant are so thed to the onotlonal. ILfe that they make It satisfactory or unsatisfactosy, and In furn koep one healthy or nake one 211, not only mentally 211 , but phystealiy 211

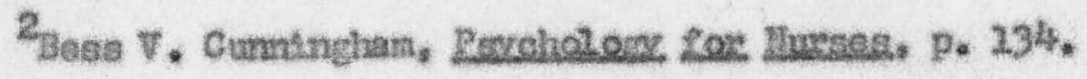

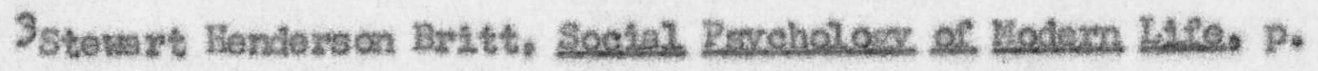
207.

4 Peretval symonds, Denemic Paxaholos, D. 36. 
as well. The prychotic porson is thought of as mentaliy 121, but has aental miness onily prodominates. Thero are physteal ecoompaninents as woll. There is the agitated patient who is aluays restless, the body sufforing with the mind. There is the violent patient who has sbnorvol strength, the body responding with the matnd. The deprossed patient is physiceliy as well as mental2y nisorsbie. The patient surfer-

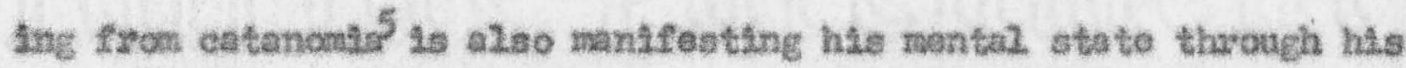
plysticel attitude. Whonever the rind and body relationship is disturbed, there is resultant psychoscmatie expression. Those 2ists of human noeds supply the key that can lead to discovery of causes.

A drive 1s persistont as Iong as the need is present. The tissue needs of the body activate these sthinuli for drives, and es long as the need perelete the viscearal or protective stimuli. arcuse disconfort. Organie drives, therefose, differ frcm porfpheral stimuli (those which origlingte outside the body) In the porslstence crer a period of tine.

When there are unsatiofled needis, thore ls also an exnotional. state, and if the need Is exphetie, the motional state 15 seute, tath boduly roaction, but if the need is ehronic, sone saet of adjustient Is mede to $1 t$, end $2 f$ the individiual does not have adechate resourees, the adjustnent will rellove the need, but there w127, be a maladjustmont as fas as its extrefeney is conoemed. All bohvior has value to tho one who uses $1 t$, go eyen a raladjustment has value. Behavior has been seleeted which has roduced the drive and has satisizied the noed.

SCatanomas is a form of schlzoplurente in whiteh the pattent maintains e rased bodily position for hours at a time.

6 symonds, s2. alt.: p. 27 . 


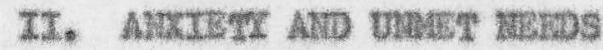

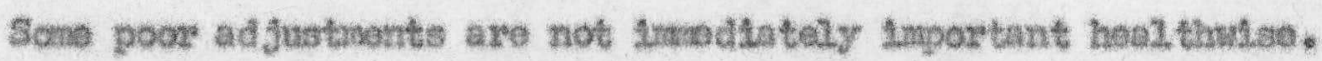
Thoy make a poos personality and porhaps furntsh the background for bite adjustronts that do mattor to the heal th, but as long as they do not irwolve ary groat catastrophe, theix hoalth effoct is minor. Anceloty in related to mary maladjustnents, and as Symonds points outs "Arceletg oceuples a loeal position in the dynamtes of human behavior, in Thero axe mery threats and eonseguent arciety-threats of competition; of fallure, of rejectton and deprivatlon, of plusteal haim, of selfestean, of adequacy and soelal status. Both oht2d and adult aro surrounded by thraats, each on his own level. Any untuletzled, untrersal. noed way Leavo tho individual with arsciety, and this anstoty leads to the eonsequence of mind and boly dLstarbance, and can lead to actura. dteoase. Much of $2 t$ mehts 1tself pronptly, and waoh other Ieads to a sort of chrente lack of efrlelency, or potentielities ready to operate In the ovent of calantitles. Ancelety need not be acute. It can amount to no more than an unoonfortabie antleipation or mood.

\section{TE curtstan's ATzTUDS}

The Bible is farl of most wonderful prontses, Sln brought anxiety as ane of lte penalties, but Cod prorides a renody even while atn is st121 with us. "Feace I Leave with you, ny pesce I glve unto

Protd. p. 216. 
7ou. Let not your heext be troubled, netther 20 t 4 be afrald, "8 "Cast thy burden upon the Lord, and he shall austain thee," 9 For 3.ass of

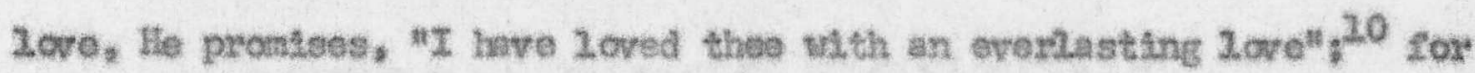

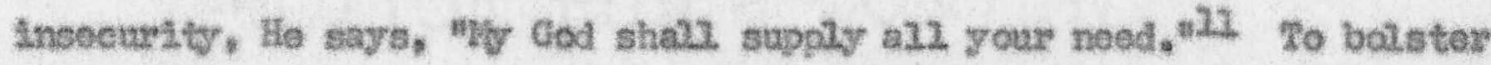
up parsonsl integrity, the Blbile saye, "I will make a man more preotous than sine gold. ${ }^{\text {n22 }}$

Orily the sense of God's presence ean bantsh the feay that, fore

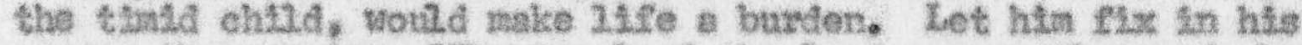
memory the prontse, "The angel of the Lord encaspeth round about them that fear Him, and dolivereth them," Lot hin read that

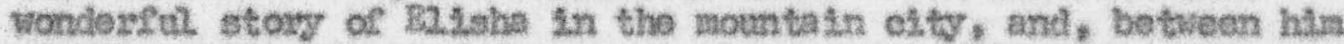
and the hosts of armed fomen, a mighty encircling band of heaveniy angels, Let him read hou to Peter, in prison and condenned to death, Cod's angel apgeared, bow, pest the armed guards, the nassive doore and great iron pateway whth thelr bolts and bars, the angel. Iod Cod's servant forth in safety. Let him read of the scers on tho sea, when to the terpest-tossed saldiers and searen, worn with $1 a b o z$ and watehing and Iong fasting, Patil the prisonar, an his wry to triel and exceution, spolco those grand woxde of courage and hopes " we of good cheor: . . . for thero atood by me this night the angel. of Cod, whose I sm, and whom I serve, eaying. Fear not, Patl; thou nust be brought boforo Caeser: and, 10, Cod hath given thoe all then that sali with thee." In the faith of this promise Paul assured his companions, "There shall not a hair fell frgm the heed of ary of you," . . "They esceped all safe to Iand, "13

\section{IV. conctuston}

In order to function, the body nust be kept in a constant state of equilibrius or howeostasis. Variations in body conditions must bo

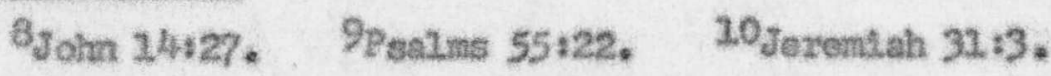

11Phatipptans 4:19. 22 Isatah $13: 12$.

23 Whate, EA., pp, 255-56. The Seriptures are Psalns 34:? and Acts $27: 22-24,34-24$,
} 
withtn eomparativaly narrow 14 ints. Snall deviations rosult in zeducod health and vitality and thon in 212 ness, and those not auch grater bring death to the organisus.

There are eertaln needs earaon to all, which when wat give

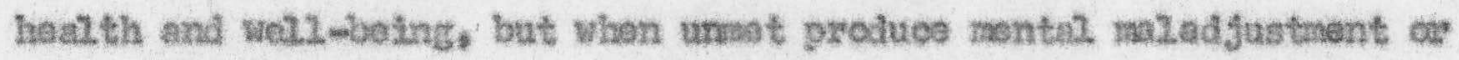
plysalcal disoasa, There needis are on both physical and Intolleotual. 2evels, provistons foe the body's needs, for security, acceptance,

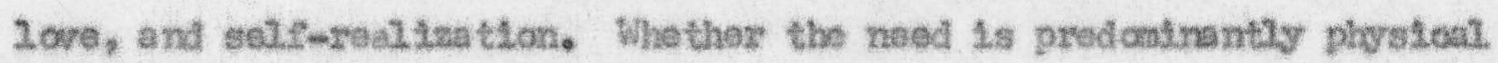
oy nental, both states operate in 2 ts fulatumont.

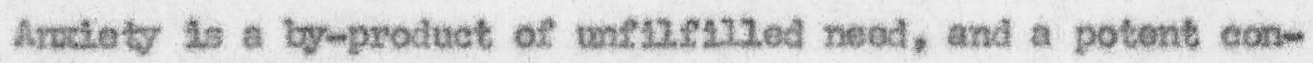
trabution to behrvior. Sin brought with 4 anciety, but to the Chriethan Cod"s Word Is full of pronases to meet al2 the unlversal noods and to care for all axciety. 


\section{CHAPTER V}

\section{T2R:}

Fin Iroment begins prenatelly and extonds throughout 12fo, The howe with Its Living conditions, and partlculany Lts form of discipline, Is the most Inportant factor in eraluronant. Othor Influenees, such as plagnates, school, religlous eontact, and comrunity, begin to operate ear2y. The oceupation makes 1ts contributton, and the widez ervironment of notionality and culture pron Ides ite shere in making poople what they are.

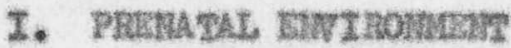

Because there are no nerve comnections between the mother and the fotus, pronatal. Influence has sometimes boen minimised, but the present trend is to give it more recognt tion. Thero may bo no norve connections, but there is chemical relation provlded by the bloodstaran. The placenta is nourlshed by the mother's blood, and In turn the placonta partietpates in the fotal elreulation. ${ }^{2}$

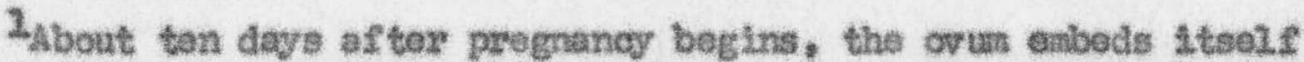
In the endontotritur or uterine 2.1ning, by a process known as implantation. This is accomplished by means of enzyme activity which algests out a spot in the area where the placenta attaches 1tsels. Afnute blood vessels are opened In this way and form tiny pools of blood. V2uli from the chorion, or outer leyer of the sae contalning the prodvete of pregnancy, extend Into this Wlood. These v1231 contain blood vessels that also go on Into the placenta, but thay do not take up the blood as such. The process by which the cygon and nutrittion fron tho nother's blood reaches the fetal olrculation is diffusion, the same 
If even the blood ${ }^{2}$ is affocted by the thoughts and emotions, a happy sraso of mind, ox, on the other hand, an unhapy mood, influences the entononte norvous system and the andocrine glands, and eventually does reach the fetus. Drugs given a mother just before the birth of the baby show up in effects on the baby when it is born, and even conwunicable disesses find thatr wey through the placontal barrier. Sarm$\operatorname{scn}^{2} s$ mother was wamed not to drink wine or to eat arything molean. ${ }^{3}$

Bspeclally does responslbllity rest upon the mother. She, by whose Itfe-bilood the ohizd is nourished and its phystoal frane buslt up, imports to it also mental and spiritual influences that tend to the shaping of mind and character. It tas Joehebed, the Hobrow rothor, Who, strong in faith, was "not airald of tho king"s commandmont, " of whom was born Noses, the deliverer of Iswael. It was Hamah, the woman of prayer and self-sacriflee and hesveniy inspiration, who gave birth to Sanvel, the heaven-2nstructed ehlid, the Incorruptilile Judge, the founder of Israel's sacred schools. It was BLAsabeth, the kinswonan and kindred splrit of Masy of Mazaroth, who was the mothor of the Serlour's herald. . . .

The effeet of prenatel. InRuenees is by many parents Looked upon as a matter of 2ittle monent! but hesven does not so regard 4 t. . . .

The vall-being of the chlid winl be asfected by the hablts of the mother. Hez appetites and passions are to be controlled by pyinefple. There is sersething for hor to shum, something for her to

way in whlch those materials reach the tissues of the nothor herself. The fotus has 1 ts own blood-naking organs and 1ts own circulation, but since the clroulation sust take in the placenta, it is routed somewhat difforently from tho postratal eiroulation.

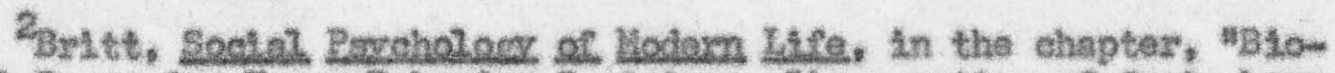

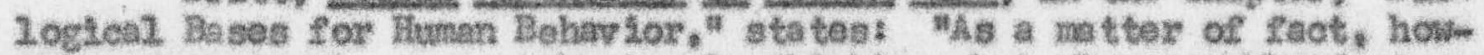
cver, we not oniy wee cur brains in thinkting, but also our blood strean, our Intomal cellviar strueture, our skelotal nusculature and our "gute" in (p. 30). The blood 1s affected in at least two ways as it cooporates in responses. (1) Its rate of etroulation is speeded or rotarded by the vascnotor nerves. (2) Its ehemical content is constantly subjected to endoorino activity.

$$
\text { 3yages } 13: 4 \text {. }
$$


work aga inst, If sho fure'2s Cod's purpose for her In glving hor a ch22d. If beifore the bisth of hor child she is self-indulgent, if sho is selflsh, Irpotiont, and exsetine, these txalts w12. bo renected in the disposttion of the chlid. Thus wany chsldren heve recelved as a birthright alnost uneonquerable tondenoles to or22.

But if tho mothor unsworvingly adheros to right prineiples, if she is terporate and seli-dexying, if she is ldind, gentle, and unsolfish, aho way givo har ohild those sane proolous traits of charactes.

Cod begins 11 s record of a human beling long before birth. "Tithine eyes did see ry substance, yet being tumperfoets and in thy bookt all wy resbers wore written, which In eontinuance vore fabhloned, when as yot there were none of theme" This 28 David's statenant, but Job is oven more spectelo with the beginning of the recond. Ilo says, "Let the day porish wherein I was bom, and the night in which it was sald, There is a man chrid conooived, ${ }^{5}$

Nofose the chlid is ready for birth, nerve connectlons are forned, and some of then are funetloning, purtleularly motor and sensory nowves.

"It soews plausible that the phenowonal fleld prior to binth is probubly aleforentiated very largaly in tame of touch, "6 Symonds soos the autononte begtiming to funotion with birth, evideneed by the Rivh of blood to the oxterior parte. The begirntng of resplration and the flust we of the vocal cords are also evidenee of autononle activity.7

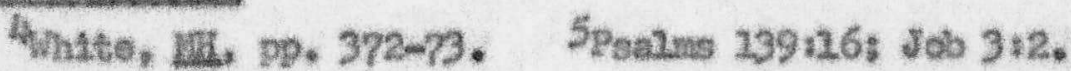

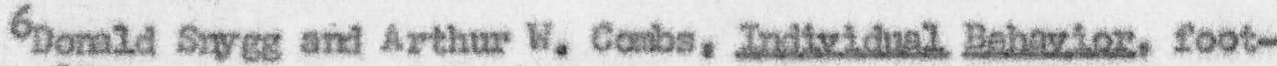
note, p. 60.

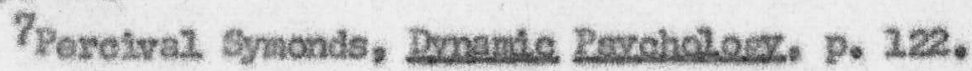




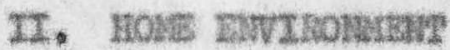

The hane furnishes the nost powexful factor in arwironnant.

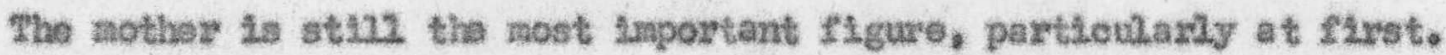

Of the more montfest kinds of frustrations, one that is eomonily

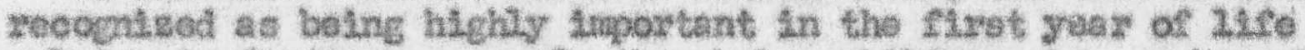
rolates to foedine. . . On the whole, childron who are brought to ehtld-guldance elinica for study and tratuent have had vesy unsatisfoctory ruxsing experiences. Freguantly they hove been nurved by their mothers for conly a fow wooks and then shifted to the bottile because the nother's athik has been inadequate, of for sone deoper psychologlcal roason, In sone cases, there seens to heve been no attergt to nurse the child at the breast fron the beginntne. Psycholocteal studles would Indleate that bottle feeding nover sutlefactorily componates for breast foeding. On the othor hand, scrae nommal children tho seen to be makine splondid adjustmonts in all phases of developiant have frequenty beon nursed by thois mothere for a period of severel months, scino times orez a yoar, and thon have not been woaned Iron the bottle unth. soveral months later. The weaning process is cre of the greatest frustration thareats exporienosd by the young chlid and nay bo thought of as a prototype of all la ter frastrations. The degroo to which a chnd is helped to make this nov adaptation oasily and without frustratton sesens to have an important boaring on tho degzoe to which this sane individual is able to meot naxy of 11 fo's later frustratlons."

Long before pryehologtets had thought of the effocts of mursting

on the Infant, Mrs. White had given the subject considerations

The best food for the infont is the food that nature provides, og this it should not be noodlossly doprived. It is a heartless thing for a mother, for the salte of conventence or soctal enjoyment, to seek $t g$ free horself from the tender offtce of nursing hey iftelie one?

The attitudes of the mothor from the vory first are of inestinable

importanes.

$$
\begin{aligned}
& \text { 8mota, p. 59. } \\
& \text { Phrte, 파. p. } 383 .
\end{aligned}
$$


It Is generally accepted that the raost potent of all influenees on the social. bohavior is dertved from the prinsay soctal experience with the nother. If a mothar nelintains tovand the child a consistent ot titude or, Let us say, Indifforonee and host13ity, the assumption is made that the chald"s porconality is gxcatiy affected theroby. His outiook on 24fe, his attitule touardis people, his entire psychle welz-being, his very destiry is presuned to ie alterod by the maternal attitude. Liso under a reglino of seaternal indifference develops a peychie pettera of gutte a datterent mold thon under a regiae of maternal overprotection. Poychtatrists regard the differenee as groat as thgugh thes ohildaron conoomed Isved in entirely different vorlds. 20

Surely the mother has prectous opportunities to guide the 2ittle one so that Its developmont sha2l. be of the highest trpe. "Even the

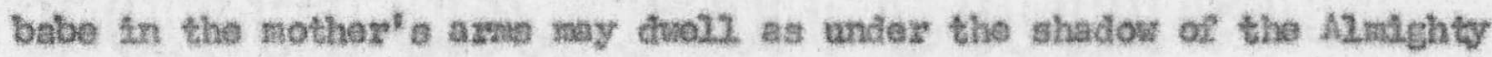
through the ita1th of a praylng mother: "i21

Intancy is not too young to begin habit-foming. Mtorv thax any neturell endownent, the hablts established in carly yoars wil declde

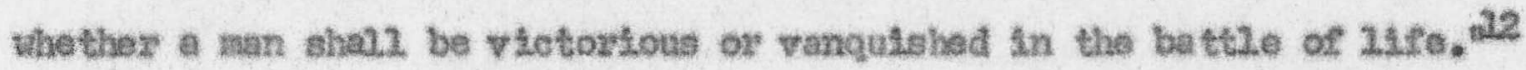
"To the laek of wight bone training may be traced the larger share of the disoese and misery and crime that eurse humanity. 23 " extont the parente hold in their oim hands the future happiness of

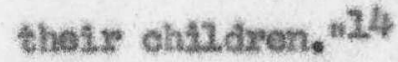

Lore and affection furntsh important background for both nontal and physteal. health-love tied to a stable, constant enviroment. that

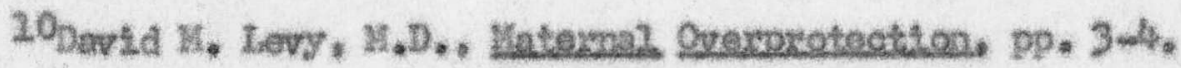
21.unte, Dis, p. 5.2.

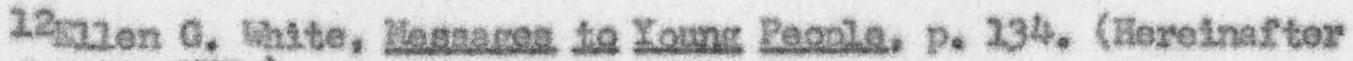
referrod to as ist?.)

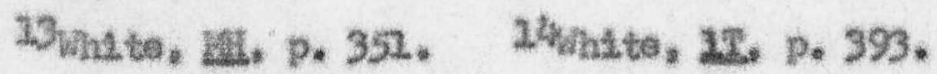


Leaves no quostlon that it 28 there ready for ary denend. In a speoch at Unton College, LAncoin, Mobraska, Hro. Ranono Deiteneyer, who wes

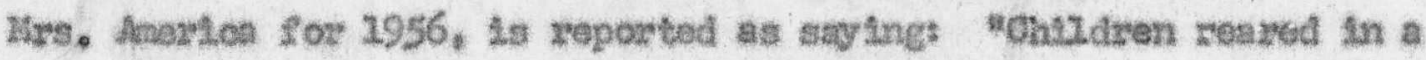
good enylumvont can vithstand viztually any earthiy stom thet may beset thoments

Frustration In infancy is an important dotemining factoz of personality throughont 1 ife. There are reasons to belleve that porsonality is forned through the frustrations experienced in irifancy. As an infant reacts to his various deprivetions and shocks, Iifelong patterns for reaction are established, 16

\section{Ix. prsctpLITE}

The Influence of the hone is not only in tis attltudes and atmosphers, but much of it is rooted in the type of diseloline used by the perents. Whother the diselpline is alld, severe, indul gont, eonsistent or donineesing, w12I tall. In the total make-up of the Andividual. Dhacialine is eleanty troated in the wyttings of Hra. Whiten Its correot mothods, its wrong methods, and the talling consequences of both.

The object of diseiptine is tho training of the child for selegoverranont. Tie should bo taught self-zellance and self-eontrol. Thexefore as eoon as he is eapabie of understending, his reason should be enlisted on the side of obedience. Lot all deeling with him be such as to show obeditence to be juet and reasonable. 17

\footnotetext{
25 ghanter Exchance. Apxul, 2959, p. 4, guoted in ecxanont under hes pleturs.

16 gymands, op. st.; P. 49.

17hite, LA., D. 237.
} 
Ralas should be sew and well considered; and when once nade, they should be enforcod. Thatever it is found lanposstbie to change, the Inind Ieams to recognaze and adapt ifself tor but the poesibility of Indulgence Induees deslre, hope, and unoertatrity, and the

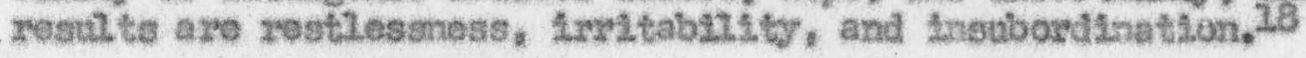

Adninister the rules of the hase in wisdon and $20 v 0$, not with a

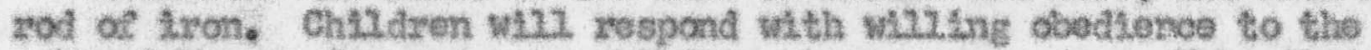
rule of 1ove, Cawnend your chlidren whenever you can, liake tha Iy Itres as hapgy as posstble. Provlde them with 2nnocont smusenents. Wake the hane a Bethel, a holy, consecrsted piace. Keop the soll. of the hoart mellas by the mantfostation of lore and affection, thre preparing 4 for the seed of truth. Remontber that the Lord gives the earth not only cloude and rain, but the beauthew. smiling swnshine, eausing the seed to gentinate and the blosscan to appour. Rernamber that children noed not only reproof and correctlon, but excouraganent and camenda thon, the pleasant stmehline of kind words?

Thare is as moh plysical heal th in these quotations as there is mornd worth. Ilot only wine the child who is Ioved, and who is taught to

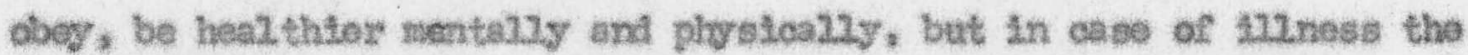
chlld who is used to doing what he is told is managable by doctors and nurses, and it can be a matter of Ilife and death, hos well, the chlld cooporrates. whth medications and troatrents.

\section{Doninaeving diacipline. Cood diseipline is a mixture of zove} and security. There are two extremes from this-oach with results of Ite orm, One extrens is orerindtulgenos, the other is too auch severity. Of the orersevere type, Nre, White says:

There are many families of ehilaron tho appsay to be well trained, thille under the treinting disctpline: but when the system which has

\section{8 pad.. p. 290.}

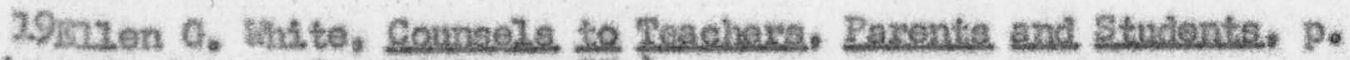
124. (Horvinafter reforwed to as C5.) 
held than to set rules is brokan up, they seam to be Ineapable of thinkling, acting, ox declding for thomselves. These children have beon so loag under Lron zule, not allowed to think snd act for thonselves in those things in which it was highly proper that they should, that they have no conitience in thenselvos to moro out upor the ${ }^{x}$ own judgnent, having an oginion of thoir om. And when thoy Eo out from thoir parents to act for thenelvelves, they are eastzy Led by others ${ }^{3}$ judgmont In the wrong direction, They have not stabtilty of charector. They have not been thrown tapon thatr om juignent as fast and as far as prectloable, and thereforg their mandis have not been proporiy developed and strongthened. ${ }^{20}$

The first adjustmonts that a chlid ases aro rather spontaneous and trial-and-error; but thoy becane refined and effoctive as he gaIne experteneo. The degree to which a person is able to weo intellizgent adjustments dotezutnes, to a large extent, his montal health, and in turn carries over into the physteal. The dontnated chlid begins his independent 12fe with many oounte againgt hils, Doninorning parents arouse eggreastveness or they eneourage subinisstveness in thetr chlld. If ageressiveness, the chlld has no precedont in his exporience to direct his aggressiveness, and where it will lead him will, dopend upon what Iniluences he ancounters, If the child reacts to his haso Alsolpline with submissiveness, he meekly accogts whatever lifo has to olfer without reats tance.

Reronts who . . can talers to no form of bolsterousness or indtiative are placing der'inite handicags on the devolognent of thely ohlidrem. These children in 2 ator years ney flnd that these strong rapressions which they have assinilated may be net with equal2y strong desires, and the inpect of them rey gave rise to sextous eorliliets and possbble nourosis. Lental health rocutree a balance botween control and freedon, and wise parents whil bo carein to evold extrenes in elther of these dixecticns. Chtidren need flrmess within reason, and yet parente should

$$
20 \text { wht te, 32, pp. } 132-33 \text {. }
$$


not bo ertreme in the degree to thitch they suppress theirs ohl2dren's spontaneous activity. 2 .

\section{Grovindwieont disolpling. The opposite of severe discipline}

2s that which is too 1ase, too indrig gent. The results, wille differont,

are no 2 ess undesirable.

There is no greater curve upon households than to alzow the youth to have thetr oun way. When parents regard every wish of theix ohildron, and indulge thea in what they knon is not for

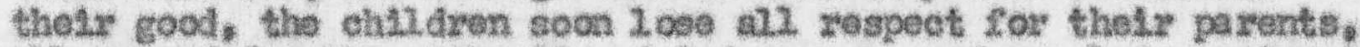
all rogard for the authority of Cod or man, and are led captive at the why of Satan. Tho innuence of an 212-regulated family Is vide-spread, and disastrous to all society. It accuanlatos in a thde of ovil that affects fomilies, connunities, and govemuents.22

A parent who dees not exerclse flirmess and control is not only falling to Induot his children into eviture in which they are expected to take tholr plece, but also may be permltting the

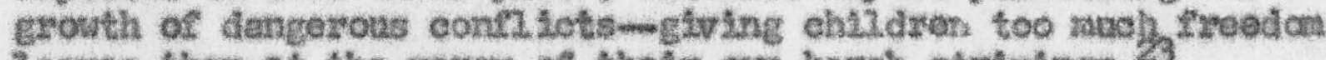
leavea than at the wercy of their own harsh strivings. 25

The fallowing ease study lulustratos the rosults of Indul gence:

Jingy A2Ien, an only ohlid of elght years, is brought to the paychologtea2 ellnie by his pazents at the inglstence of his teachers. The parents aro much incensed and regard all this as a direct insult to the fanliy. They ralse a thousend complatrits agalnst the school. and are conpletely at a loss to understand the situat thon. J4my, they tell us, is a delisghtrul chlld at home. Ho has his moments now and then, but on the whole he $1 \mathrm{~s}$ Kother's and Daddy 3 darling, the center of a confortabie suburban hone. Jlary plays whth a eroup of younger chlidron than he completely dontrates nuoh to the dellight of his father. His slightest wish is his parents' ecamand. lils manners are delightrul. vith edults and he speaks 1.1ke a polishod young gentlenan, With the adults at the elinte, he is calm, polsed and heipful, too helpful for a ehtzd of eight. The parente foel the schocl mast bo a vory territile place for thoy polnt out that Jinng Just hates to go

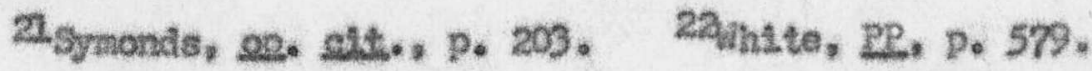

23 Symonds, an. att., p. 202 . 
thore and crtos and bogs to stay hane. Ho has even mado humself olelt over 1 t and had to stay hone bocause he got so upset.

The roport fron the school on Jymu prosants a vastly different ploturo. His tesehere conpleIn that he $2 \mathrm{~s}$ "not brlght," stubborn, and a "very nasty chald." Ho does not get along woll with the otho: chlidron, baats up tho younger ones, and brws aff tho older ones with Lallipops and Ileorice ahoostrings fron the store across the stroet. In class he is constantiy tallang and showing off. He rast always bo the conter of attentlon. He 21kes art work and this is the only thing he does well. Whenowar his worle is displayed, he brags instrferrabiy. He has boen lenown to oheat on exains. When he lost the lead in tho play rocently, he sldpped sehool. for three days in a rous. With forty chudron in plass, the teschor is at wits" ond to know what to do with hin, 24

This chtid is conpletely at a Loss when 1 eonos to adjusting outsidde the home. He lknows no other zale than to be tho conter of attraction. Ho is alroady satting up condt thoning for an adinent

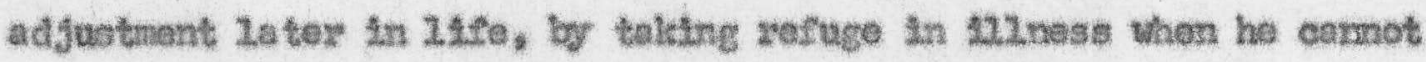
talerate a situstion.

Relectlon and diserintmettes. Nojoction and discrimtnation anount to about the aame thine to the child. A chatd can be partinuly or totaly rejected, or he nay be tho vietin of pastiality unfovorable to hatr, If tho partlolity is to his advantago, 14 places hin in the cless with the orertindnged child, but If unfavorable, he $1 s$, to that extent, zojoeted. Every basie noed of such childron Is violated, those nooda for Lare, security, acceptonce, and edif-Worth, Such an exparLence disqualteies hin for satiefactory religlous exoreleos, for be carnot unierstand Cod who suppiles 2 ore and eare, when his envirorenent

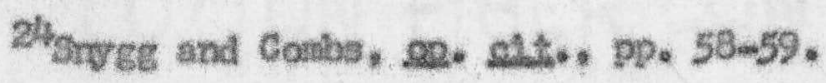


has novey denonstrated steh to hin. Some of these persons sean stie

to rise above the elreunstances of their oxperience and find campensethons, while othore are grosely maladjusted.

. . Loved and Loving faotlitatos adjustment to sltuations that Irvaive strong unpleasant enotlons. When a Lorod child falls at sonothing, the fallure doos not out so deep ss to make hin doubt his baste worth because he $2 \mathrm{~s}$ stzil secure in that 2 ore relationship. Consecuentily he is more easily roussured and encoursed to tyy again. In contrast, the milovad chald who faile is in double jooperdy. To his Insecurity is added the foeling of inatequacy. and the vorld looks blacker and blacicer. When a lored ehild is frightened, be can 1iterelly or Ilguratively take the hand of the perton who loves him, approach and examine the terzifying sltuaton, learn its true dinonslons, and more readuy find the courage to faco 2t. But terroz to the unloved ohtzd Is unfacoable and everwhelming. Funishuents, penaltios, and the denends of authorlty are bearable for lowed chlidwen beeause they do not inply rejection or fundanontal 2aek of worth. Cansequently they are andyzable by the Loved chald, who more caslly can percotre thelr moaning and take them in stride. But to the unzoved chind these things may be taken as indLestors of personal rejoction or of unfavorable status. Flesentaent, robelilion agalnst authortty, hostitisty agalnst peere who seen more Lavored, or fundanental. doubts of own worth. ensue. 25

In the author" s experimes with student nurses were two who Fividay 2ulustrate the results of the mind on the body restitting froas rojection. These two gtris vere of about the same age. One was fron a happy, secure homa, the othor, an megitimate chl2d, was reared in an orphan's hone. She had been tried out in six or seven Lostor hones, each time to be roturned to the orphan's hone. Wheh to hor arodit, she has made every etfort to componsate. Hor nuxwes" oducation represented this. She was eager to do all that she was supposed to do, and her

25 Dantel A. Prescott, mole of Lore in liunan Development, " p. 5. (Unpublishod manusezlpt.) 
hunger for friendshlp was pltiful, bat to those who befritonded her, she auns with more thon acceptable tonacity. One contrast between these garls was in the way they responded to 211ness. The gaxl from the adequate howe, while often 132 with minor alinents, always recorerod prosptly and was back on duty oven bofore she felt vory woll. The

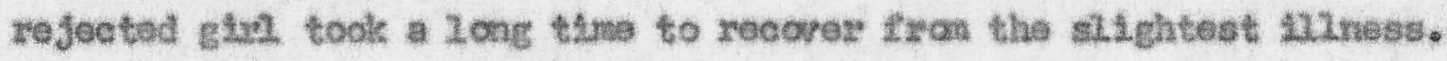
Sho was in bed with pain, Itver, nauses and voniting for nore than a weok aftar the extrection of an Impactod whsion tooth. The other girl. would have been on duty the noxt day. This extonded Lilness was not malinger2ng, but the plesteal exproseton of an unsot enotlcasal need.

Inconststant disetriline. Another kind of disctplins that tends to maledfustnent is inconslstent diselplitno. The chlid is confused. The diseiniline is serere one day and Indul gent the noxt. The parent may correet in angor. "To manifest passion touard an exring ohtld is to Inorease the ev2l. It arouses the worst passions of the ch2ld and

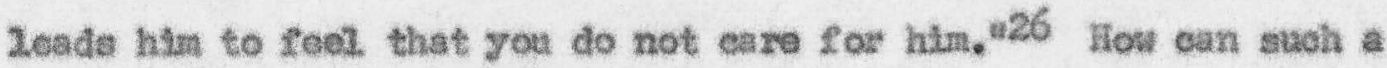
ehsid devalop habits of 20 geal, stratght thinkingl lie is cortainly a candidato for $2 a t e r$ maladjustment and nourosis.

The attnosphese of the hage. Diselpline doos not restrict ftself to measuros used to meet crises oz to the punishuont of disobedrence. Yitch more of It is Indireet, the result of the a tnosphere that pervades the howe, the atmosphere that, nakes the hose a hepry place or an

26raion 6. White, Ghide Cutdanca, p. 245. 
unhapry one. It embodies forces and cohorence that hold parents and ch2ldran in relationship. It Ireludes attitudes and responses, give and telce, In a constant form of Iatont ecntrol. Each chard feels It fron the oxiliest infency through adolescenee. It is this potver that shepes the pexsonality. Good disclpitine that is eonstant and conststent produces good. heal thy pexsonalithes. "Abore all else Let poxents

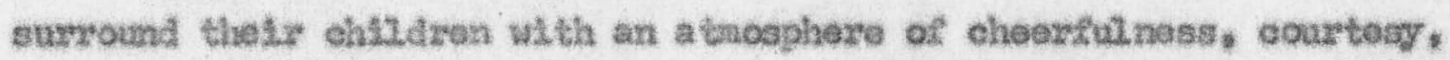
and Love, 127 Diselpline that has been too scvore, has been Interrupted or suffered tragedy, Loaves 1 ta nark on the chald concemed.

Anong the elfents who case to a counselos with personal, problenas a voxy considereble proportion are chlldren of divoreed paronts. Sonotime during thetre chlidhood, Lane before enotlonal, growth was corpleted, they have beon confrontod with problens of confliteting Lojalties that would have strained even the eapacitios of vatur1ty. . . .

Children In these honos have had to Lean to cope with blttemess; batred, nogiect, and confuston, and to put up sarse gort of dofonses against the arxioty such attitudes bsing. 28

\section{Schoot. EVIRosurew}

Another mistake of parents is to sot too high standards of conduet and accoaplishnonts for their chuldren. Waronts may arouse aggressive tronde in a eha2d by the Ixposition of high standarde of

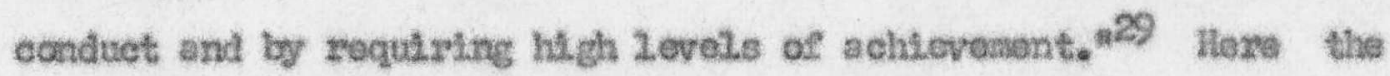

$$
\begin{aligned}
& 27 \text { 2bid., } 9.146 \text {, } \\
& \text { 28 Leona E. Tyler, the Lords of the Counselox, po. 5-6. } \\
& 29 \text { Synonde, 22. ext.: p. } 75 .
\end{aligned}
$$


superego $0^{30}$ is irvolved, and the superego, thus trained, Ls conditioned for undentrable attitudes such as excessive drtva, radicalism or conptiston, or at best, tension and aredoty. Hastering amxloty fleures prodantnant2y in enotionel. dovelopmant. Whan a chtld beglns sohool, he has wary now restraints and new demands as vol2 as nov ski2ls to 2eam. Cextainily the good of the child would be furthered by alloutng for the develiopnent of proper maturity to reet these denande before he must take then In such a Large ordex In the schodroan. "The violenoe whth whioh ohizdren rush from sehool. at the ond of tho day is testinory to the Lang hours of enteorced restroint." 3i

We have pushed chlldren Into small muscle activitzes, stroining ears, focusing the eyes and manipulating the rino musclos of the fingers, all of which tend to cause tenston. These mall ruscles develog last. . .

Thero are many indica tions to show us that $2 \mathrm{f}$ snall mascle activ1tLes, even reading, writting and aztithentie, were postponod a fow years, the ghild would plok then up gulelaly with much greater effilatency. 32

long grars before sclence made these discovarles, Whes, Whit to provided the counsel that chaldren should not be sent to sehool too earia.

Parante should be the only toachers of tholy chlldren until they have reached elght or tan years of age. As fast as thalr

30 Suporego is the psychologteal term that is practicelly equivalent to conselenee. Ego represents tho self as lt interacts vithin lts oun confines to the external eralronient.

31. Symonds, 22. s1t.. D. 75.

32 Jay B, Nash, Teachahla Lonants, pp. 189-90. 
minds can conprehend $2 t$, the parents shovid open before than Ood's great book of nature. The nother should have less love for the artifictel. In her house, end in the proparation of her dross for display, and should find timo to cultivato, in harseli and in her chlidren, a lore for the beautiful buds and opanine 12owars. Dy calzing the attontton of her chaldren to thelr different ediors and variaty of forms, she ean make then soguainted whth Cod,33

\section{Colpantonsmap}

OutsIde the hane, the eompantonship ohosen by or for ehaldren

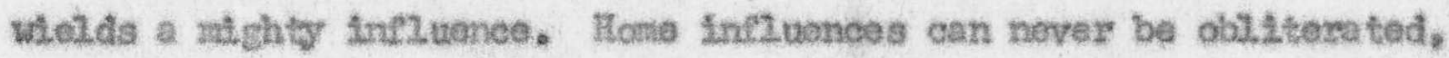
but thoy can be greatzy voakened by assoclations outstide the hone. Not only the chlldren, but adults are supyed by the conpantons thoy choose.

It Is ratural, to seok compentonship. Every one w117, find cont pankens or mate then. And Just 1 in proportion to the atrength of the eriendehip, wirl be the anotrnt of ineluence whtch frlends w211 exert orez one anothex for good or for ev11. A71, whil, have

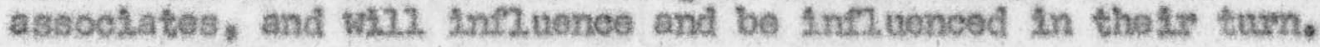

Tho 1ink is a rystemlous one whtoh binds human hearte together, so that the feolings, tastes, and principles of two Indtviduals are clovely blended. One catches the spirlt, and coples tho was and aots, of the other. As wax rotains the figure of the seal, so the rind retains the Inpression produced by intercoures and association. Tho influence may be unconselotas, yet it is no 20 ss powerstul.

If the youth conld be pexsuaded to asisoctete with the pure, the thoughtful, and the antable, the effect would be most selutars. If

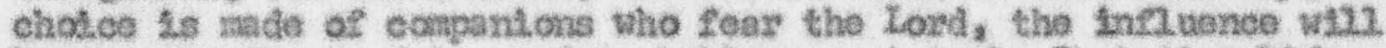
load to truth, to duty, and to holkness. A truly Christian Iifo Is a power for good. But, on the othor hand, those who associate with nen and women of questionable morels, of bad, princtples and practlees, will socn bo walking in the same poth. 34

33 (Herelnaftes referred to as E.)

34thate, kes, p. 58 ?. 


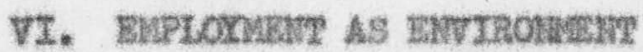

The jos doas much to make Indtviduals what they sure. The conpantons sat on the job, Its reguiranents and satlsfactlons, all place their stang on the workex. The attitudes of druigery with which the work is performed heve a great anount to do with mental heiteno. If a woxker sponds forty hours a week on tho job, and carries with ham nary moxe hours of thought comeeted with it, mery convereations highty predoatinetang in shop talk, the job is no amall Item in happiness and eattafaction or in boreden and dLssetisfaction. Overwork need not be a factor at all in a nervous breakdoum. An unhapro, but necessary, job can certalniy generato emotionel problens difflenlt for one to handle. A teacher is being deseribed in the following quotation, probebly one who loves his woxk, but who stinl finds problems on the joh.

So weswing are has resoonsiblut thes that speetal effort on his part is recuirred to prosoive wigor and froshnoss. Orten ho becones heart-140ary and brain-weany, with the alnost lrresistible tendency to depression, caldnoss, on ixwitability. It is his doty not moroly to rosist such woods, but to avold thatr cause. 35

He who practlees Salonon's advioe, Whatsoovor thy hand IIndeth to do, do .16 with thy inght, ${ }^{3} 36$ has a measure of rencoty for problens prosented by his job.

Ile who discerns the apportunitles and privileges of his work wizi allow nothing to stand in the vay of eamest endestor for solf-imprevemont. Ho why spare no palns to xeach the ht ghest standard of excelizence. 37
35whte, DA., p. 277 .
36 Reclestastes 9no. 37insto, Ed.. p. 282. 


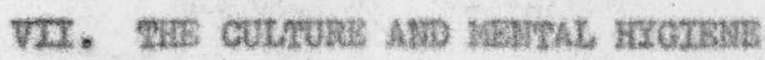

Hou much mark our oulture seles on we is hard to reallze. One eountry, deftclent in resourees for Its population, presants a predonInance of nutr2tional. diseases. Parabltieal diseases are frequent in parts of the wor2d, and workinge eondattons also have thelre influence on the 217 nesses of an arva. Pexhape no place on the earth or no time in tho world's history has presented so wany neuroses are there are at the present time in the materially prosperous United states. Nodesn Iivine containly makes donsuda upon the nerpous systam. There aro other places In the world where work is hard, deprivations nany, but whero neuroses haraly extst.

Sovoral joars ago Nargaret Kead visited vartous uneiviluzed tribes in duffoxent pleces in the world in order to study thoir culture. In the Samoan Ielands she discovered that girls do not have the violent adclescent problems that Amsrican girls have. The bables are nursed until. they are three or four years ad, and then are turred over to the next alder chi2d. Hil teaches the oht2d sron then cn. Precoctous ch2ldren are hald back and slow children are given extra opportunt ty. so that thore is an everness of developnsnt. Girls are taught to regard boys as present eneales and future Lovers. Narriago is a matter of soolal and economite conventence and divoroe is easy to obtaln, Morals are someshat lax.

In llev Culnee there were two tribes of very opposite character2staes. The Arapesh ele found to be a mild, trusting, affectionate 
people. Competitlon and aggresstreness were absent. Iven the ehuldren's garaes were not competitive, and if chlldron quarreled they were separated. The llundugunor tribe was quite different. They wore warlike and camnibailstic. They do not velecme the birth of a chizd, It reeetves no extro attention and no 200 while nursing, and is pushed awey as soon as $2 t$ finishes. "Weaning is done eariy, and the ehlla gets eross words and blows, 38 These axe certainly realistie examples of envizonnent and erfect.

\section{OLD ACE AND DVIFOUWEN}

When planning for ald age, people usualiy think of econonie securlty, and plans are guided to this end. Sosne attention, but not enough, 2 g given to neetang the enotional needs at an age when the personal resources are depleted. Some geriatride ${ }^{39}$ emphasis has been given to adding life to years as well as adding years to Iife.

I was shown David entreating the Losd not to forsake him when he shovid be old, and what it was that called forth his earnest prayer. He sav that most of the aged around him were unhappy. and that unhappy traits of character increased ospecinlly whth age. If persons were naturelly elose and covetous, they were most disagreeably so in thelr ald age. If they were jealous, fretful, and Impatient, they were especialiy so when aged....

Dev 2d was deeply mored; he was distressed, as he Looked forwerd to the time when he should be aged. He feared that God would leave him and that he would be as unhappy as other aged persons whose course he had noticed, and would be left to the reproach

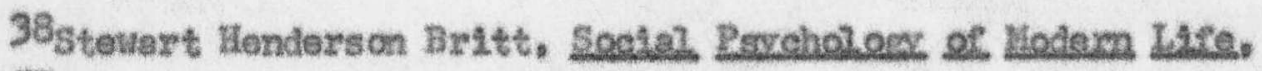
PD. 52-57.

39 Cerlatrics refors to the medical eare of the aged.
} 
of the enentes of the Lord. With this burden upon hin he earnestly prays, "Cast me not off in the time of ald age: forsake mot when iv strength falleth."

\section{IX. concrusion}

Fron pronatal. 24.10 to the greve environnent, with a prevalling mental. hyglone aspoet, the $1.4 f^{\circ}$ is molded and the health and happiness are affected. Patterns of reaction and bohavioy are more fimiy Itred as time advanees, The home sets up the first rodels by means of Its attltudes and discipline. Barly, too, the chrld's associates begin to eontribute. The school is an important part of axy ch2ld's hoalth. The early attendence at school, adds tenstons and frustrettens, predisposing to later maladjustment.

The eulture in whlch one IIves holps greatly to shape the Individual's mental heal th. Religlon, education, expanlonship, and emplqyant are an ralated to personality. These help to proulde problems as well as satisfaetions. Bven in old age the onvironmont is stili Important to the enotionel health, and to mind and body relations. ${ }^{4}$.

40.hite, 22, pp, 422-23. The Seripture is Psalms 7.29 .

4I See AppendIX A for material relevant to this chaptex. 


\section{GHAPTER $n$}

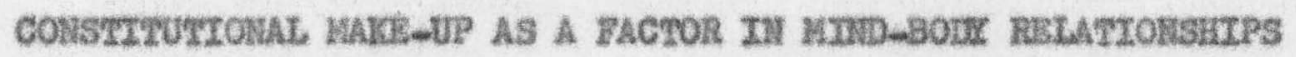

The salation botween heredity and eny Iroment has furntshed some Interesting study. The questzon of which has the nost to do with the Individual becones difftcult to answer. Nevortheless, the fact romains that both ake thely contratbutlons and both are to be reckoned with $2 x$ the study of hesnan beines.

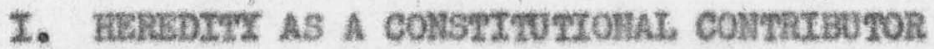

There is much in prychologteal. Iltersture on the Infinence of heredity and emrironnont on plvaleal development, parsonality, and oven character. The acturl physical body 10 , of course, horeditary. The nexborn infants in a nursery anply testify not only to differont phys20al. nake-up, but to temporamental. differonces as we11. One baby wi21. be plactd, always asleop, wh5le another w121. be essty avakened and diffleult to pactiy. Termorament has its source in the nervous gratem, and 1t w111 be acted uson by enviromant as the baby grows.

When God made man a free moral agent, lie made t.t posstble for hin to acguire cherseteristles through lesming. Sons of this Leaming becones subject to his free cholee, sone of it is provided by the arvixorment, and even the enviroment ean to quite an extent be andipuIated by the Indistidual. SIn and temptation Introduced the Iaw of death with Its sorrow, anciety, and frustrations. The delieate balance between the sympathetle and parasympathethe neives was upset by the 
sorrow, anxiety, and gu12t that sin wrought. In this way physieal degeneracy became a part of human hexitage.

The book of Conesis gives quite a definite account of soolal and Individual. 2ife, and jet wo have no record of an infant boing born blind, deaf, cxippled, deformed, oz inbecile. There ls not an Instance upon record of a natural des th in infency, childhood, or early manhood. There is no account of men and wonsen dying of disease. Obituary notiees in the book of Cenesis rum thus: "And ali. the deys that Adan Lived were nine humdred and thirty years s and ho died." "And a2l. the days of Seth ware nine hundred and twelve years: and he died." Conoeming othors, the record states: He Ilved to a good ald ages and he died. It was so raxe for a son to die before the father that sueh an occurrence was constdered worthy of records "And llavan died before his fathez, Terah." Haran was a father of ehlldren before his death.

God endowed man with so great vital force that he has withstood the accumulation of disease brought upon the race in consequence of perverted habits, and has continued for six thousand years. This fact of itself is enough to evidence to us the strength and electrieal energy that Cod gave to man at his oreation. It took more than two thousand yeers of erime and Indulgence of base passions to bring bodily disease upon the race to any great extent. If Adan, at his ereation, had not been endowod with twenty thmes as much vital force as men nou have, the rece, with their prosent hablts of Iiving in vidation of natural $2 \mathrm{aw}$, would have become extinct. ${ }^{2}$

\section{DTSRASB AMD GEREDIY}

Actual hereditary discase, as such, is restricted by several Pactors. For one thing 1 it is 1 kely to be recessive, and for another, the genes and chromosones nust be Irvolved, and this factor is well. provided for by the Creator in waking them almost insceesstble. Prenotel disesse is anothex thing. In such cases scus thing happons during the prenstal period of develognent, and as the ehromosomes with their

$$
\text { Hoste, 32, pp. 138-39. }
$$


genes bave already made their contributlon to the Individual, steh conditlons are not passed on. They can only assume the same status as postnatal. Incidents.

Characterlstics which cause the zost eoncern axe very of ten belleved to be due to recessive genes (genes carrying latent tra Lts uhleh do not necessart2y show up but which can be transindted). Sone feoble-mindedness, certaln forms of insentity and a susceptlbility to certain diseases, such as diabetes, are frequentily ilsted among tratts which can be inherzted through a conbination of recessive gonos. Aceording to this theory of inheritance, a racessive tralt cannot be passed on if 16 is present in the genes of oniy one parent. It rast be carried by both parents; moreover, the genes cazrying a trait must be palred. ${ }^{2}$

Exythroblastosts, an infant anenta, is caused in a spectal, way not understood untul the last twonty years or so. The mother has an xil negetive blood,and her fotus, mall poettive blood. The fotal blood Is Incompatible with the mothor's blood, and she manufacturea antibodies against st. Then these antibodies, in turn, destroy the red blood cells of the fetus. Unless the disease becones too advanced before birth, it ean be suecessfully treated with a camplote replacenent of infant blood by means of transfustons.

Since blood types are hexeditary, this disease is necessarily hereditary in this sense. In anothey sense the disease is prenatal. Only the infant's blood type can be passed on to the next goneration, and it has the sans potentialities as the blood type of ary other

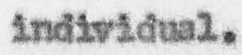

Another hereditary disease is hemophilia. In this case the

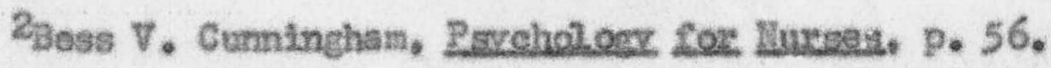


causative factor Is attached to the $X$ chronosone. Whan a male ehtld receires this $\mathrm{X}$ chromascone fron his ruother, he beccues a blecter or hemophulic. Since the mother has two X chromoscruos, not every one of her male chtldren needs to develog hemophilla. A fonsle ohlld nay recelve this chrongene, but she doos not suffer from 1 te presence. It becones eansative only then paesed on to her male offspring.

Syphills was at one timo constdered in threo eategories:

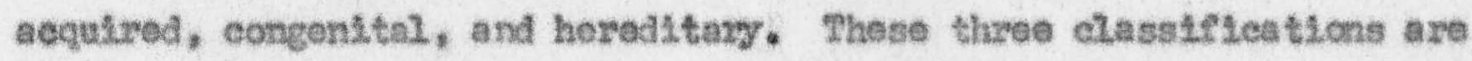
Given In the dider books; the never ones elthor do not mention hereditary syphilis, or call it hereditary syphilis whon a congenital gyphil is

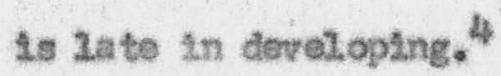

"Constitutional differences such as $\nabla$ igor or veaknoss and sus-

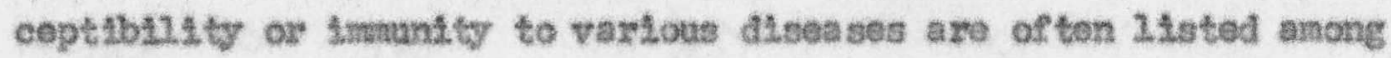
heredLtary traits." 55 And hare are to be found the most frequent heredltary mansestations. It is this constltutlonal horedity that figures In peychosomatic possibilities. Os course, constitutional alenente enter Into othor disceses, and they are more evident in some psychosomatic patsents then others.

3remales have two $\mathrm{X}$ chromosones and males an $\mathrm{X}$ chromoscme and a $\mathrm{X}$ chronosono. If a ehild zecotves an $\mathrm{X}$ chrounosome fron the Lather, a

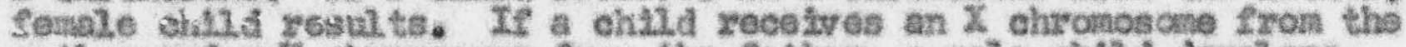

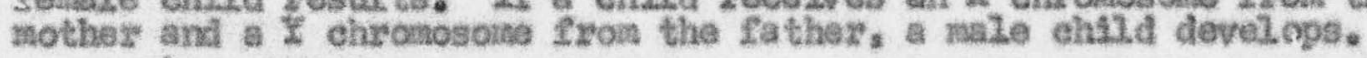

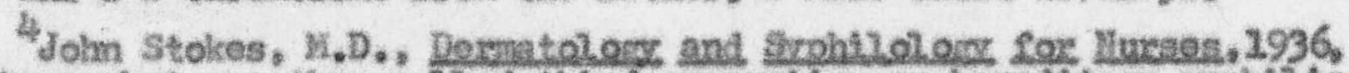
recogntaes what was then calied thizd-generation or hereditaxy gyphilis.

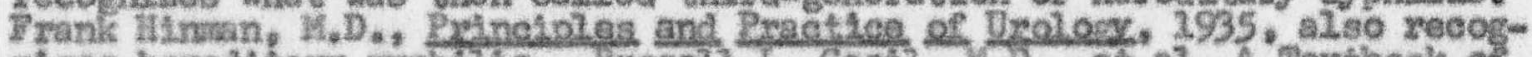

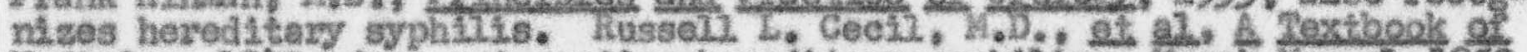

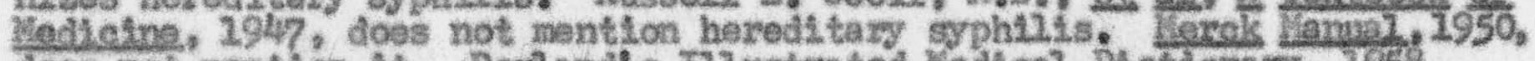

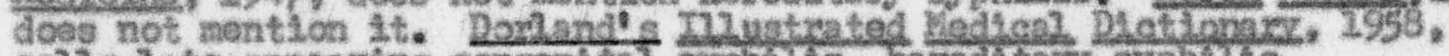

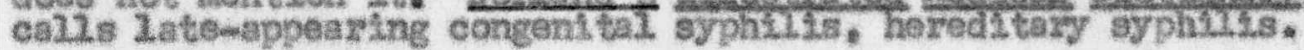

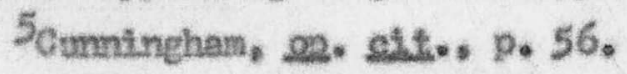


This constitutionsl bsckground is aeen in Dr. Edward Podelsig's deseription of the heredity equipenent of the kind of individual who suceunbs to gestric of duodenal wleer. Such porsons, he says, have a defintte and elear-ut type of personality. They are extremely conselentious, and they set hlgh standards for therselves and attompt to reach goils in an obsessive and conpulstre way, goals which most people would not atteupt. They are inteli igent, overactive, independent, and they aro tense. He describes thom as having a good sense of humor, and they heve swift and strong resetions. 6

\section{THE NEW}

Dx. Walter 0 . Alvarez writes much that is valuable in understandIng the nervous background for disease. He admits his own poor nervous haredity, and this gives hili a sympothetie approach.

There is a group of persons whon I of ten think of as heving sane te the end of thetre cope nexrousix. Usualiy the pattent is a young wonan who, with a poor nervous heredity and sane constltutional Inedequacy to begin with, managed sonehow to keep going for years in spite perhaps of having to work her way through sehool, then to work 2ong hours, then to do wueh for a lot of unroasonable and denanding relatives, then to go through the sorrou of a broken engagenent or an unfortuna te maxriage, then through mach iliness, and I inally an operation or two. To me the wonder is not why guch a woran broke down, but how she kept golng as long es she did.?

Stagney well deseribes the part played by heredity and the nexvous systen:

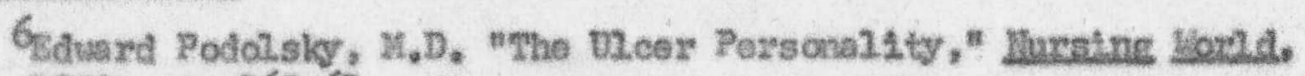
August, $1950, \mathrm{pp}, 362-63$. 250.

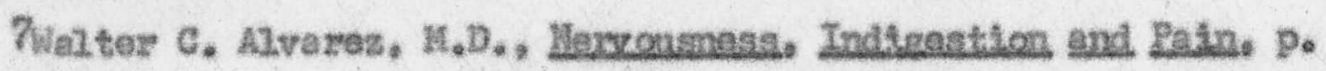


The autonomic nervons syoten is a signiflcant factor in determining Individual. differences in personal.t.ty and in influenoing develogmental secuence in a given individual. Varlous studies have shown that difforenees in aronsal, duration, and contral of autononde aetivity diffor from person to pereon as regards ease of aetting off changes in the blood pressure, psychogalvante rontex, pulse rate, end so on: In the length of time reculred for these functions to veturn to nomal; and in the extent of control of visceral. functions. A good deal of evidence supports the view that these vartablas are related to personality treits In advits. There Is also sone reason to belleve that the development of the young

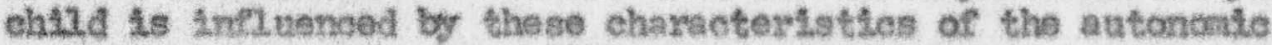
nervous system s.g.; 3 child with a highly renotive autonomic w112 probably acquire condlit Laned enotions noro read12y ond thus w211. derelop atthtudes and expectanetes rather alfforent stom his brother\%, whose viscers are less songlttve,

Dr. Alvarez gives a classte 17lustratton of hou hilghy sansittve

the norrous eystem can be:

I sald one day to an attrective but frasl and hyprsens 14tve Iittle violinist, what does a symphory concert do to you?" and, as I expected, she saId, "It takes me into the seventh heaven, but it toars me all. to pleces enotionally, and I cono hans a wock," But she agreed with ne that it was better to be that vay than stupid and insenst tive, 9

Then he goes on to expla In the mechanism that produces such sensitivitys

I point out to the ivpersensltive wonan that she must sufter: If only because she is so sonsttive: sounds, snelis, Ilght, a ireft, the ticlitng of a eloek, things which are not bothorsone to the oxdinary person, beat In an her bralr and wear her out....

One can find much about this painfulnoss of visual, atulitory and

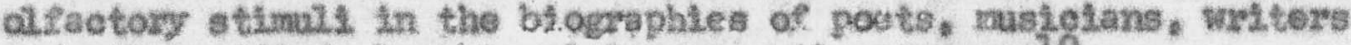
and other glfted, hyporsenst tive neurotic persors. 20

\footnotetext{
Boss Stamer, Recholory of Rarsobaltiv. p. 92.

91varea, on. olt., D. 130 .

20 Lbid.. p. 60 .
} 
Another difficulty often met whth by the hpexsenst tive vonan Is that she becones mpleasantly conselous of the vorktres of her organs whtch she never iknew she had before. Thus, whlle recovering Iram a postinrluenzal dopression, she may feel hes hoart beating. or she may be annoyed by the throbblug of bey earotid artery where At passes noas the Irmer ear, or she may feel. the writhing norements of her intestine, or the contrections of the 2 ittle ruscles of hor skin. The more effort of putting up with such sensations and not gotting alamed over them adds to the sun of the day ${ }^{1} \mathrm{~s}$ rathgue. 2 .

These quotations should make 16 elear that thare is a vast dif Lerence in the rarvous systems of different Individuals. What will. be hardly noticeable to one persen may be the source of wach ammoganes and Alsccurort to another. The sensitive person is going to be subject. Iay nore often, to psychosonetie alinents, then the insersitive individual. Also, the same person dLffers at different thmes in degreas of sensttiv1ty, due to vartous reasons.

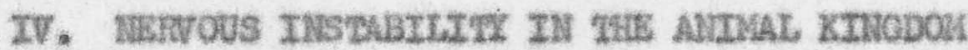

Nervous instability appeass as a herodittary trait in the antmal kingdon as woll as in the hunan fantly. A flock of highbred Leghorn hons vil go linto a stanpede if the housewifo cones to their pen weasIng an aproa when they are used to sesing her without one. Herde of rogistered Jexsey cors are suscoptible to windy, disagreeable veathor, whlch whl slos up thelr milk production. Professor Lloyd Morgan tells of a 12tten of Pive pups that he took for a walk. They cans to a gate with bars so elose together that the pups eould not get through. A12.

$$
21 \text { Itotiles pp. } 230-31 \text {. }
$$


the 12ttle dogs struggled to get through at the bottom, but falled. Eventualin three of then discovered that they could get through the bers higher up. One other pup eontinued to strugele, but the iff th one gave up and Lay down whining. This intoresting expeximent ho ropeated sovoral times, always with the same results, These IIttle fellows were each bom with a alferent equipment. 12

\section{ConcLustow}

The work of physteal deganeration commenced In Iden is stizI progressing. Heredity produces a widespread varitety of traLte. There are a sew diseasos that are inherited, but nostly eonstitutional inhorttaneo accounts for the type of disease to which an Individual is suscoptible. Certaln constitutions are wore sensitzve to peychoscustie disease than others. Even among anjinals, who have no reasoning powers, and who lenow nothing of thely physical make-up. there is ovidenee that they have dufferent nervous systens.

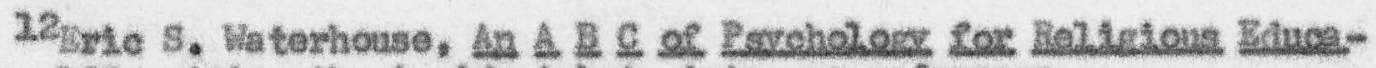
tien, p. 102, eleting the inetdent but giving no referenee. 


\section{cupTer VII}

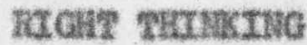

Basie to good nind and body rolations is right thinking. The wrong thinking that began under tho troe of lenowledge of good and evil sprang from Satan's appeal to self-oxallation: "Yo shall, be as gods," This attitude has brought ruan to him and his angels, and what ruin it has wrought to the hunan fanliy! The vory fact that sell-proservation holds such high Inportance in hunan welfare makos it easy to place upon solf a disproportiona te anount of thought and attention.

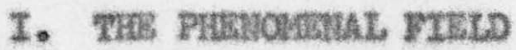

The reel situation in mind-caused diseases is not, "She thinks she is siek," but that her thoughts have made her sLek. Dr, Alvarez in his book, lowroumess, Indkeustson and Rain, wontlons "yeara of wrong thinking," He refers to the fussbudget, the worrier, the perfectionist. Fach of these has wade for hinself an atmosphere in which he 21 ves. Ivery porsco has what is called a "phenonenal. Ileld." This phenoronal. fleld represents the world of thought, a personal universe 2uled with Ldeas of the past, present, and future, and the Individual's selfassigned relation to this realin of inteliectual activity.

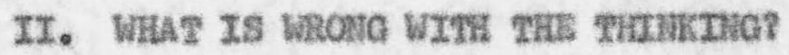

Nany are diseased physlcally, montally, and moral $4 \mathrm{y}$, because their attention is turnod exclusively to theraselves. 
That which bringe sickness of body and mind to nearny all, is dissatiofled feelings and discontented repinings. They have not Cod, they have not the hope which reaches to that within the vall, Which Is an anchor to tho poul both sure and steadrast. A11 who possess this hope wlil purtfy thonselves oven as he is pure. Such are free fron seotless longAngs, ropinings, and discontent; they are not gontinually 2ooking $20 \%$ evil and brooding over borrowed trouble. 2

If the phonononal rield is fulled with self, whth the unhapry things that occur, with alights and fallures of 1 Ife, with fears and anxieties, with tension and worzy and resentrent, the thoughts aro wrong.

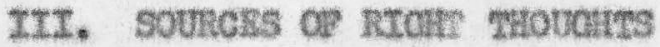

A good model for right thinking is given by the Apostle Paul:

Final2y, brothron, whatscover things are true, whatsoever things are honest, whatsoover things are just, whatsoever thinga are pure, whatsoover things are lovely, whatsoover things are of good report: $1 f$ there be any $\nabla$ irtue, and $1 f$ thore be ary pralse, think on these thange?

There is a selenee of Christianity to be watered,-ma selence as much deeper, broader, higher than ary husan selence as the heavens aro higher than the earth. The mind is to be disclplined, educated, treined! foz wo are to do service for Cod in vays that aro not in harnony with Inborn inclination. Ilereditary and cult2rated tendencies to ov1工 must be orereome. Osten the edvestion and training of a lifetins mast be discarted, that one may becone a Ieamey in the school of Christ. Oux hearts must be educated to bacone steadrast in Cod. He axe to form bablts of thousht

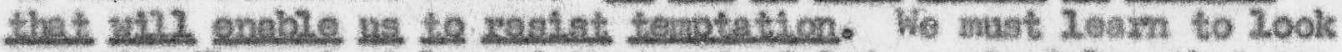
upuard. The prinolples of the word of Cod,--principlos that are as high as heaven, and that compass eternity, -ive are to undorstand in their bearing upon our da2zy Ilfe. Ivery aet, every woxd, evory thought, is to be in accord with these prineiplgs. AJi. must be brought into harnony with, and subject to, Christo"

\footnotetext{
21040., D. 566. 3Phnzippians 4:8.

Whate, MH, pp, 453-54. (Italles supplied.)
} 
Even when performing one's datly toll the mind may be occupled with profltable thinking.

So in every Iine of useful labor and every assoctatlon of Life, the desires us to find a lesson of divine truth. Then our dally toll will no longor absorb our attontlion and lead us to forget Codi It waII continuel2y remind us of our Creator and Redecmer. The thought of cod whll run 3 , ske a thread of gold through all, our homely cares and oceupations.?

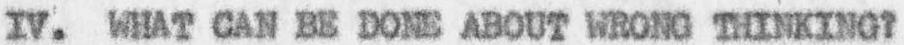

With such high ideale of right thinking, how can they be reachedr Surely there is no self-seekting, no replning, no arxiety portwayed here. To reach such Ldeals no doubt Imrolves a Long and gradual. grouth, and wuch offort. In handling our problems, we so often txy to make selfJustification cover gutlt and make corgromise stand for vietory. The result is only continued teneion, when the mind needs the peace that canss from cosplete surronder, the same assurance that Christ gave when Ile added forgtyeness of $\sin$ to 11 is mitracles of healing. There are things that ahould be forever settled, for as lone as they are left dangling there will be tenston. NeIther should they be repressed. They noed to be completaly cleared up. Right thinking should set the montal house in order and keep 1 t so.

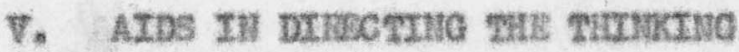

Chaldhood is the time to form habits of happy thinking, and ch2zdron can be difrected Into channele of hapgy thought. One mothez:

SWien 6. White, Ghrtat's Obioct Lessans, pp. 26-27. (Hereineftor referred to as cor.) 
with a chald who habitumlily awokoned from his nap orying, deternined to make a happier ohild out of him, She gave special attention to this ehizd unt23 the habAt wes brokon, thon ho began to stir from his nap, she was on hand at once to take him up. She soothed him and provided hin with sonething to divert his attention, and in due time she was ropald with a hapgr ohizd.

A change of thought habits can also be inftiated in adults. Deelsions ean be made and helps set up to check bad thought activities and to eneourage good ones. Some of these could bet

1. Supply the mind with good thought materiel, fron reauing and Irom 22stenting to what Le good. The mind needis maxy resoureas.

2. Assoctate vith people whe are models in the thought area to be tangroved,

3. Rofuse to mull over sl.1ghts, personal injurias, worries, or whatever might be distressing. This can be scearplished by hoving selected ahead of time sone tople for thought to which the nind can be instantIy switehed. Live orey a lovely trip, recall a pleasant visit, ropest poetry or Serspture. "It is a positive duty to restet melancholy, discontented thoughts and feelings, - -as much a duty as it is to pray, "6

4. Keep undestrabie topics out of the eonversation. Mixpresston deepens impresston, as is vexy wall known.

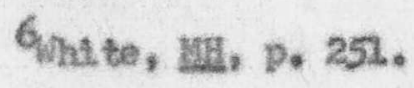


5. Seek new interests that wi11 provide now subject matter for thought.

6. The outdoors is invigorating, fresh atr is restorativo, and nature Is inapirational. So conplete a ehange of atnosphere suggests new forns of thought. "Excercise in the open aly should be presextbed as a Life-giving necessity " This instruction can rightiy be expondod to Inelude both mind and body in Its application.

7. Finding ways to serve is certalniy one way of redireeting thought.

The flfty-elghth ehapter of IsaIah is a prescription for maladies of the body and of the soul. If we destre health and the true joy of ILfo, wo must put into practlse the rules etven in this geripture. Of the serviee acceptable to Him, and its blessings, the Lord says:

"Is it not to deal thy bread to the hungry, And that thou being the poor that are cast out to thy house? When thou seest the naked that thou cover ham,....

8. "Song is a weapon that we can alvays use againet discoursgenent. As we thus open the heart to the sumight of the Seviour's presence, we

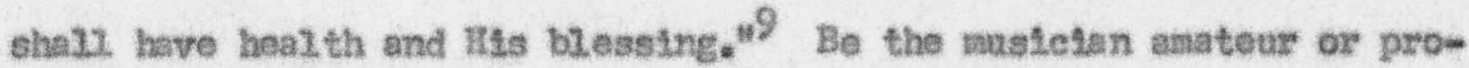
foss 2 onal, a pleno is a cood place to work out enotlans. If the musie Is rightig seleoted, the player cen cone away with nev inpulses and Iresh courage. Mifothing tends more to promote heal th of body and of soul. than does a splrit of eratitude and praise. elo

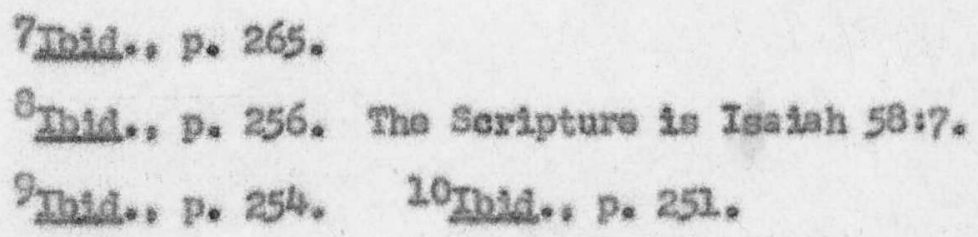


9. The mind needs beauty. "The king's daughter is all glortous within, "11. She has chosen the best subjects for hor thoughts. She has brought herself under the infruenes of $0 \mathrm{~d}^{\mathrm{t}} \mathrm{s}$ grace.

In the matchless gift of HIS Son, Cod has encircled the whole world with an atmosphere of grace as real as the alr which clreulates arotmi the globs. AMI who choose to bres the this Ilfe-giring atmosphore w12. 2 ive, and grow up to the stature of men and wonen In Christ Josus. 12

Nollo May says that "1.1ving creatively meens growing, expressang one's potentielitias, developing one's posszbllitles, and therefore finding continuously new interests in persons and thinge, ${ }^{\text {w3 }}$

\section{VI. concLuston}

If the phenomensl field is fliled with self, It will moan selfIshness, Alscontent, deprosston, pessintsin, Pears, Inadequacy, worry, anxioty, enry, enulation, and strife. When the hungry are Sed, the naked clothod, and the outcast taken in, the thinking takes on the right color. Right thinking finds heights of nobslity and Insplration of purpose when it conterplates hesvenily holiness centered in Christ. Effort in the right direction will lead to this goal. Which can be done to elininete Irom the mind thoughts that are a hindrance to host thful IIving, and to leam the sxt of thinking such thoughts as wi11 result in happiness and effoctive Living.

\footnotetext{
11 Psaims $45: 13$.

22mien $G_{0}$. Whtte, Stens, te Ghrith, p. 72. (Hereinafter referred to as se.)

231 Ralo hay, Soxines os Grative Livinge. po 18.
} 
Influences that hat upon the wind run lnto quite a 12st, beginming with those rudimantal, rosponstbilities of paronts and reaching a

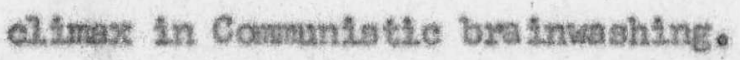

\section{x. conscrowes matumo}

The develognent of the nind beglns early, before there is ary Indiv1dun2. mora2. responstbi21ty. The paronte provido the matertal. that buflds Itself thto that has Iong been lmown as consclence, and what paychlatrists now call suporego. The suparego may be modifled by Iater exporience, but the original w112 always retain much of its validity. The ehlid first Ieams restrietrons. He muet not touch the hot store, he wast not put eartain things Into his mouth, ho must keep out of this and that. Quite largely the superego is negative. As Intelzigence Inereases, the chtld Is able to take on nore positive Ideas, and tho suparogo beconos modirtod by the ego Ldeal. The balanee between these two has wuch to do with personal.t. ty.

\section{InLumes}

Another outsite source of montal. activity is inmuance. Dvery person is a pert of those with whon he has associsted. Moral responstblatty applies to inmuence, for the cholee of assoolates ls largely voluntexy: 
Nontal control ascends a seale of intonsity in suggastion, pressure, dominanoe, and propeganda before It reaches ite elinax in the forms of hypnotism and brainweshing. Universally all of these foroes are becouting more intense and more subtle.

\section{ITI. Mass 1200IA}

There is a constant bombardmont of the senses contng from radio, televiston, the printed page, and outdoor advertising.

A now factor has beon added in human ilfe so radieal in noturo that the world can never be guite the same againt it has been callod the rovolution in canumication. ... The great danger of this 1ies in the conmerelal tost of all our values. The truth sonotines becones subservient to sales promotion, and the mo thods used appeal to the least comon denominator enoticns of sex, succoss, and popularity. Therofore, the indirect product of this barrago of persuasion is to develop a moral atnosphere that pleces clanour abead of Integrity and sales results ahoad of truth. The extent of orer clains for producte in press, radio, and televiston has becone so notorious that it is even the jest of chlldren. Hevertheless, advertisers continue to make survers that they say prove their effoetiveness. Bither the advertisers are vastiy orerrating their sezvice or they are providing a lind of persuaston that jecpardizes the basic values for which wo struggle as Christians. ${ }^{2}$

The suggestlons so used axe well studisd and extromely indirect. Mary of the appeals are unconsclons and sublintmal, yot they register In the mind and affect opinions.

\section{Dosmatro:}

Domination is a form of mind control, in porhaps a lesser degree thon hypotism and bratmashing. It exists in govornments, and it is

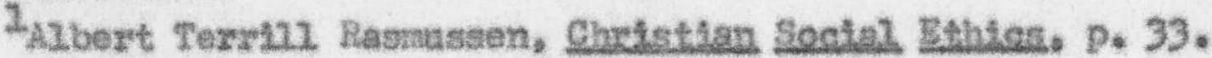


a payt of the progran of somo churches. Domanation formed the franework of the porsecutions of the Dark Ages. Domination has been counteracted in the republican form of gorernment. Progress and eni.ightenment heve followed, for relief from domination roleases initlative. Dut donination may stiul exist in the hoarts of those who think they 2070 freedon. Teachers nay employ donina tion, and in mary hones there is an autocrstie fom of discipline. If the control of one mind by another Is wrong, then dorination is wrong even when emploved with eh12 dren.

To direet the chalda's developnent without hindering it by undue eontrol should be the study of both parent and teacher. Too much managenent is as bad as too 11tt2e. The effort to "break the wil1" of a child is a terrible mistake. Minds are constituted differently; while force may secure outward suimhlssion, the result with maxy chlldren is a more detomined rebelliton of the heart. Dven should the porent oy teacher sueceed in gaining the control he seeks, the outeono may be no less haraful to the child. The discipline of a huran being who has reached the years of intellizence should differ fron the training of a dumb animal. The besst is taught oniy submisston to 1ts master. For the beast, the master is mind, judgnent, and will. This nethod, soretimes employed in the training of chi2dren, wakes them 11ttle more than automatons. HInd, w111, conselenee, are under the eontrol of another. It is not God's purpose that any mind should be thus donlnated. Those who veaken ox destrey Indiridua2.1ty assume a responstbility that can result oniy in evil. While under authority, the ehllaren may sppear 14ke well-drilled soldlers: but when the control cesses, the charseter will be found to lack strongth and stesdfastness. Having nover loamed to govern hinself, the youth recognimes no restraint except the requirements of parents or toacher. This removed, ho knows not how to use his 2iberty, and often glves hinself up to indilgence that proves his $\operatorname{rosin} \theta^{2}$

$$
\text { 2mate, Ed.. p. 289, }
$$




\section{DRUCS AID THE MIID}

Hay aedieations act on the brain and nexvous syetem. A suxprisingly large section of pharuacology is taken up with drugs that affect the nervous system in varlous ways. If the heart rate is too rapld, a drug is given which acts on 1 te nervous mechanism to slow it down if the optanetrist wishes to dilate the puplls for aye exantnatlon, he nses a drug which aets on the nerves that regulate the size of the pup1ls. If It seens desirable to reduce stonach secretion and motility, as in gastrie wlcer, druge are used which depress the parasympa thetie nerree, for these two functions are stimulatod by the parasyapathetles. If pain atust be controlled, the drugs used are those whteh aet on the sensory nerves, Bven lwdrotherapy and sone other forns of phrsical therapy depend, for their reatits, upon nervo actlon. Heat dilates the blood vossels and increases the elreulation to the part. Cold contracts the blood vessals, but the blood vessels dilate and contrect through the action of the autonomite nerves. There are various rehex ereas that are used in hrdrotherapy to gain certain results. These areas are reflex because of their nerve distribution. 3

The Ithe of dosarkation between whe t is legitinate and what is hamifur in drugs is easily confused. Dr. Meerloo writes a very profltable and Interesting book called Rase of the Wind. He is a Dutch psychlatrist, and as a prisoner of war, came in cantact wtth aind control.

3See Figures 2-5, pp. 72-74. For explanation of the Plgures, see Appendix B. 


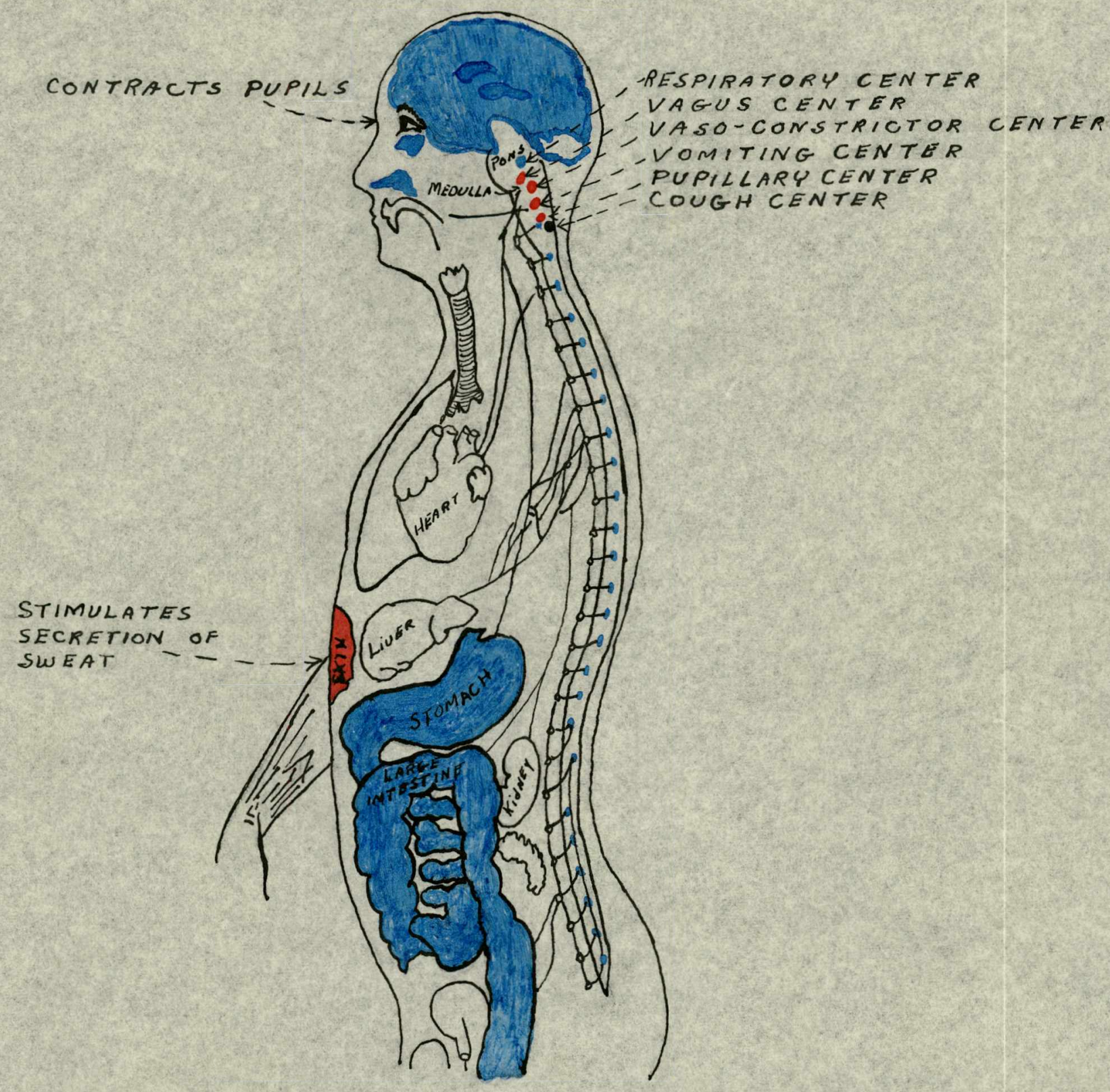

FIGURE 2.

Figura Illustrating the Effects of Morphine

(Code) Red: Stimulation

Blue: Depression

BlumGarten: Textbook of Materia Medica, Pharmacolooy and Therapeutics. Macmillan Co., 1941. 7thed., Chapter 26. Pase 408. 
DILATES PUPILS

PARALYZES ACCOMOOATION

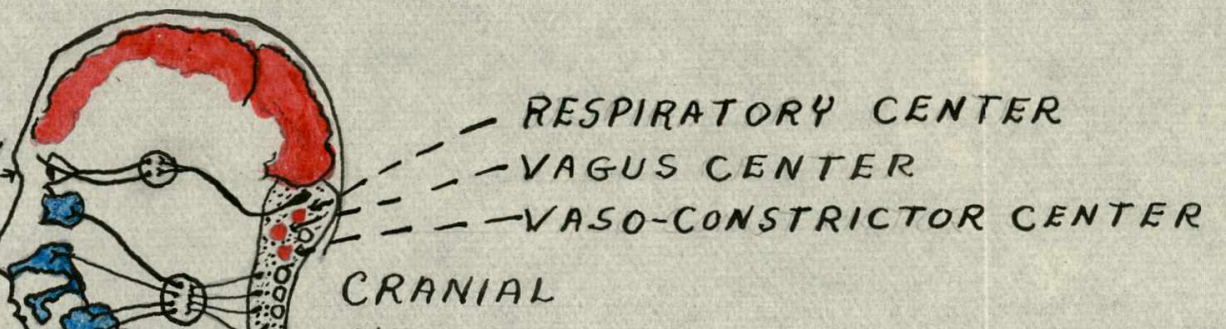

NERVES

CHECKS SECRETION of SWEAT DILATES BLOOD VESSELS

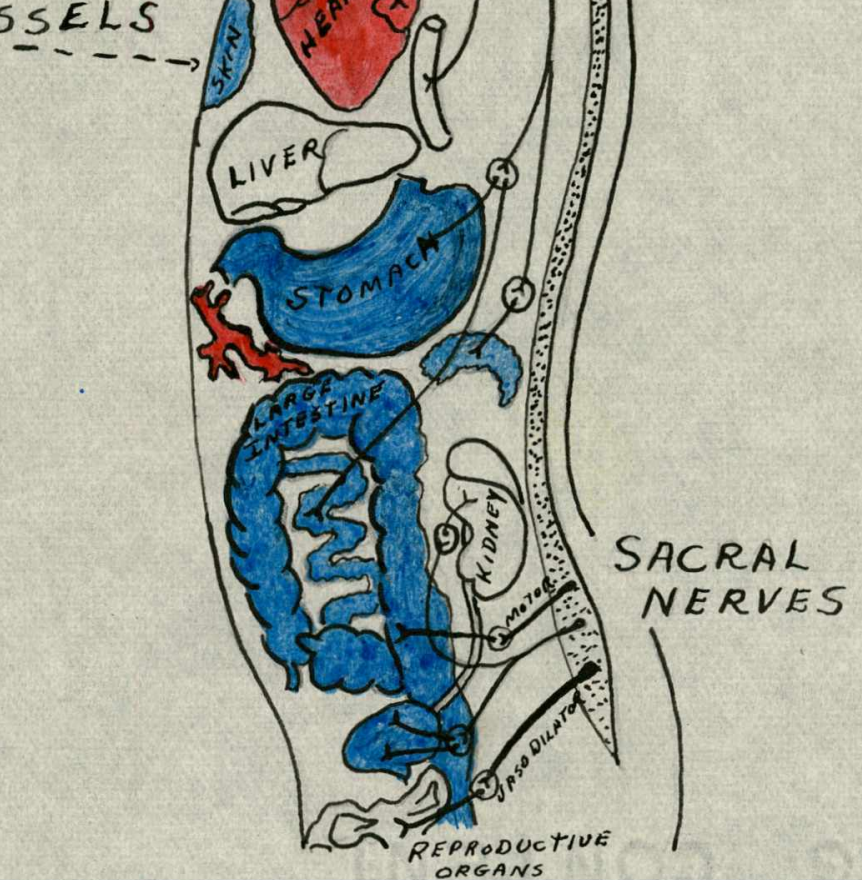

FIGURE 3.

FigURE Illustrating the Effects of Atropine

(Code) Red: Stimulation

Blue: Depression

Blumgarten: Textbook of Materia Medica, Pharmacology and Therapeutics. Macmillan Co., 1941. 7 th ed., Chapter 31, PhGe 519. 


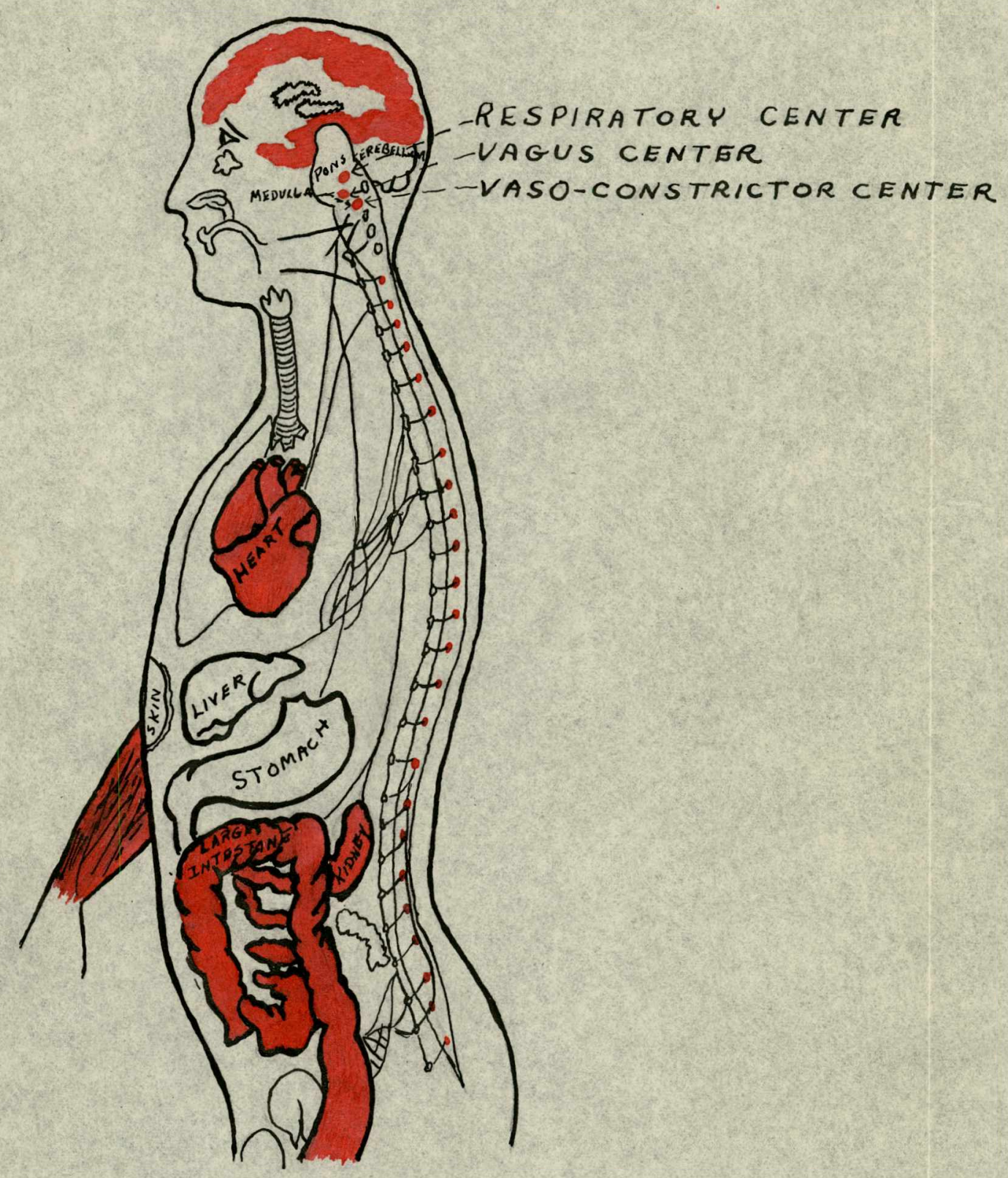

FIGURE 4.

Figure Illustrating the Effects of Caffeine

(code) Red: Stimulation

BlumGarten: Textbook of Materia Medica. Pharmacology

7 th ed., Chapter 25, PAGE 386. 
FIGURE 5.

REFLEX AREAS

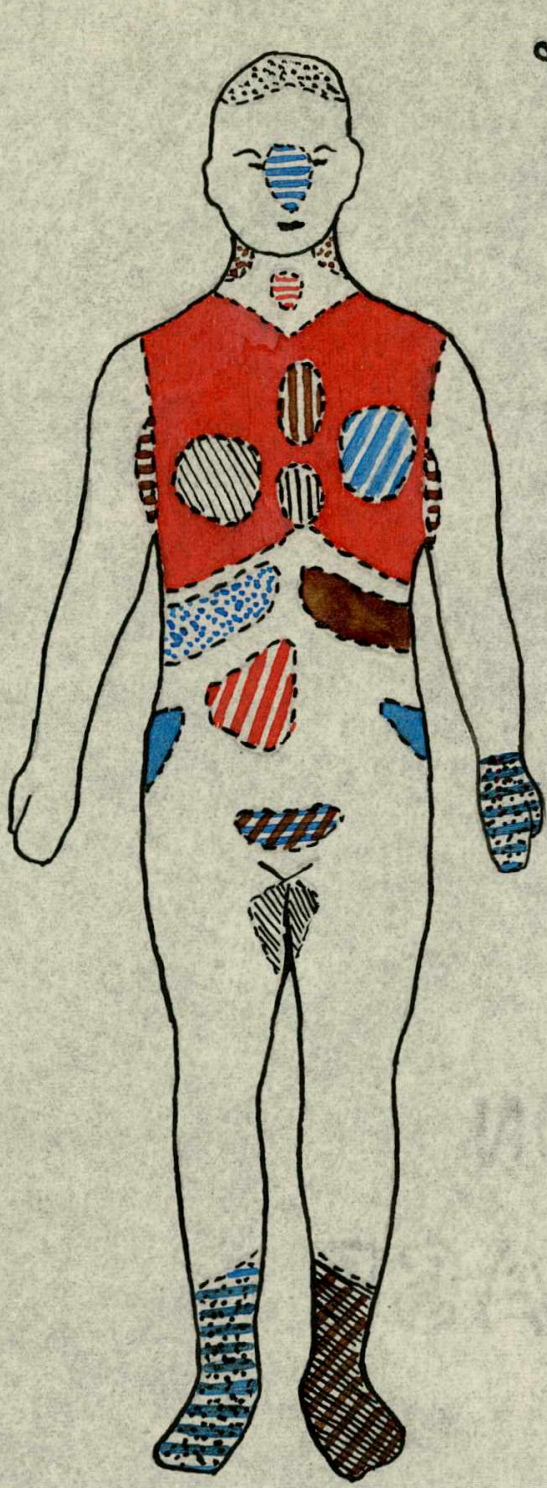

ANTERIOR

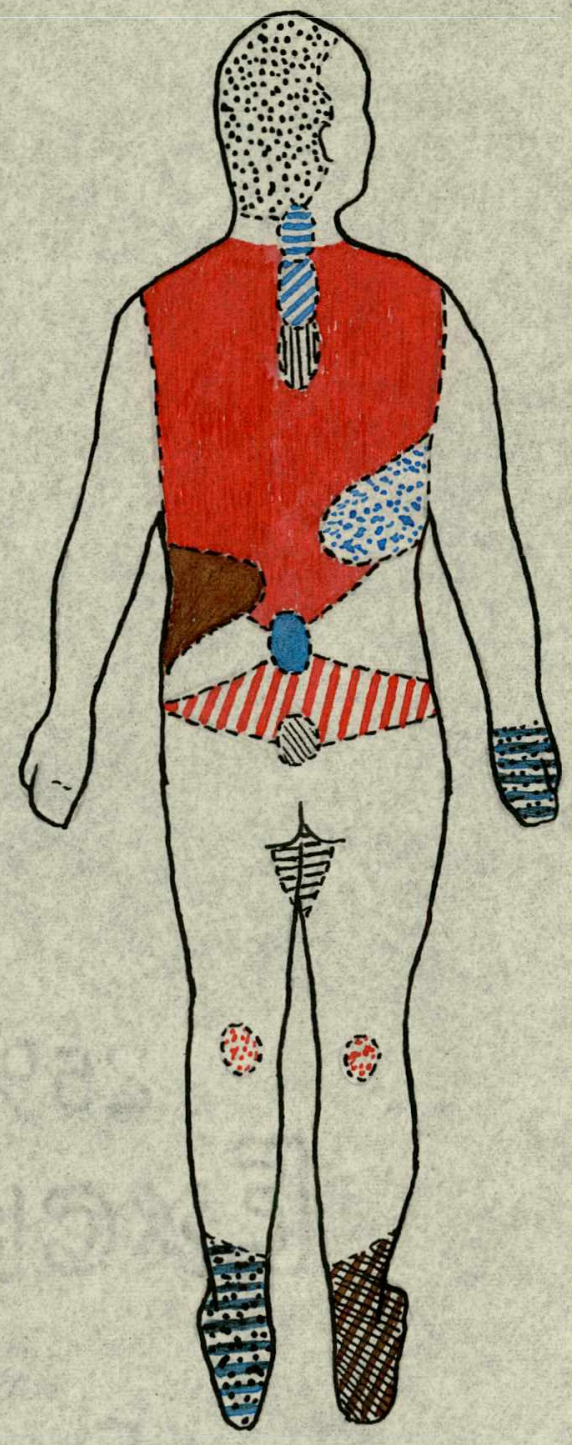

POSTERIOR

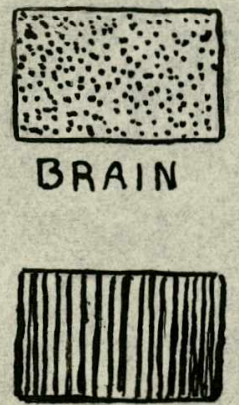

STOMACH

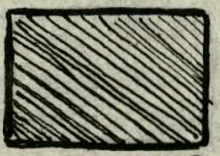

UTERUS

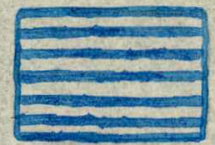

NASAL MUCosA

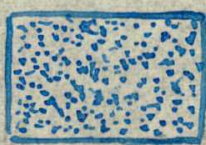

LIVER

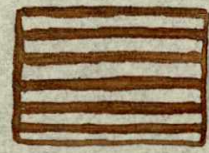

AXILLARY ARTERY
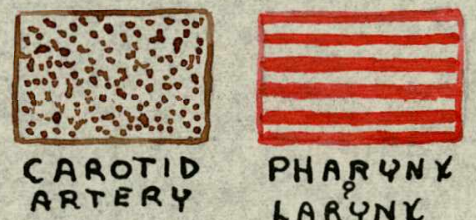

PHARQN X

LARYNK

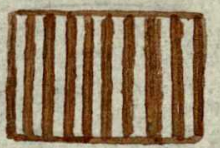

ESOPHAGUS LUNGS

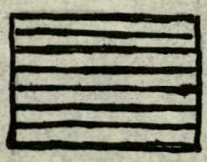

INTESTINES PROSTATE

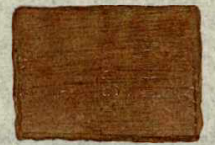

SPLEEN
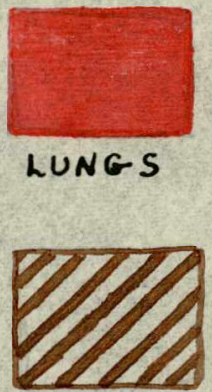
BLADDER by Mary C. Noble, R.N.

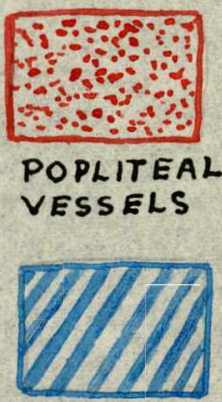

HEART

Abbott, Georce Knapp, M. D., Physical Therapy and Nursing CaRe, PAGE 61. Desion arRenged 
I w112 touch upon another stde of this problem as well, namely. cur dangerous social dependence on various drugs, the problens of addiction, making it easier for us to slip into the pattern of submissivoness. The alcoholle has no nental back bone smy more when you give bin a dirink, The same is true of the chronie user of sedative or othar p12.2s. 4

One stretegy of the totalitarlan nations was to ereate an artiflotal shortage of drugs generally used, and replace them with berbituretes, which were evallable whthout preseription.

\section{TES LIE DETSC20R}

D2. Neonloo discusses the 2ie detector, nareo-analysis ${ }^{5}$ and lypnotisn, ane of which Invade the rind. He warns:

There is a very sertous danger in all those mothods of chemical. Intruation lnto the mind. True, they can be used as careful alds to psychotherapy, but they can also be Irightening instruxents of control. In the hands of non vith an orerwhoining drive to pover, 6

The Ile detector, he belleves, belongs to the category of mind control. for it farees Its viotin to adnit his gualt, and since enotion fron the oxdeal con affect rosults, he bolleves it can be unrellable.

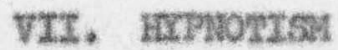

Dr. Heex2oo Lays bare lypnotism as a mothod of mind control. He calls it the "bastard son of fantasy and reality."u?

\footnotetext{
4Joost M. A, Neerloo, M, D., The Rape of the Kind, D. 55 .

5pychiatrists use narco-analysis in interviews with patients to malce them abie to rolease mental resaryations, by use of a drug and th more easi2y. Aleohal does the sarne thing for a drunle man. Durlng World War Ir this procedure was nsed on Americsn prisonsrs. Wen who know top military secrets carried a suicide capsule to take if they wero captured.

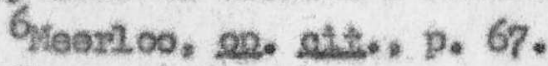

70rlike Hirs, Whate, Dy. Weerloo approvea of hypnotlsm as a remody
} 
Balen $C_{*}$, Whate explajinst

Thoxe $1 \mathrm{~s}$, howover, a form of mind eure that 1 s one of the most effective agenstes for ev12. Through this somctlod selenee, one mind Is brought under the ecntrol of another, so that the Individvality of the weaker is merged in that of the stronges mind. One person acts out the winl of anothor. Thus it is ola smod that the tenor of the thoughts may be changed, that hadthnglving irpplaes may be imported, and patients mis be onabled to resist and ovexcone dבssease.

This nothod of curo has been enployed by persons who were Ignorant of ats real nature and tendency, and who belleved it to be a meuns of beneflt to the sick. But the somedled selencs is based upon false principles. ${ }^{\circ}$

It Is claimed that a hypnotized person cannot be campelled to

vialate his conselonee. Dr. Neerloo makes exceptions. He says:

Meny paychologtsts would dony thot such a thing could happen and would Insist that no person can be compelled to do mader kpposis What he wotld refuse to do in a state of alext coneciousnese, but aetually what a person can be compelled to do depends on the degree of dependency that ivpnosis causes and the frequency of yepetition of thi aomcalled posthypnotle suegestions. . . True, no hypnotizer can talko awry a man'a consclence and imnor resistanco imodiately. but he can arouse the latent nurderous wishes which may beccise active in his viotin's uneonecious by eontInual suggestlon and eontaknual playing upon those deoply ropressed desiros. Actual. knowledge of wofhods in bralnuashing and mentielde prove that all this can be done.

Another woason why lypnottem la wrong is because 1 t Amolves the wม1า.

The w112, that forms so trupartant a factor in the character of man, was at the fall given into the control of Satan; and he has ever since been working in wan to winl and to do his own pleasure, but to the utter ruin and alsery of man. 10

In the bands of reputable praetitioners, but he also points out the denger af the subject's being taken advantage of by unserupulous persons.

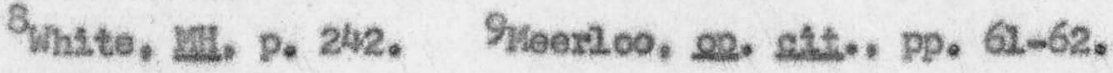

$$
\begin{aligned}
& 10 \text { white, 58, p. } 525 \text {. }
\end{aligned}
$$


Wypotism Lets Satan get Just a 21t lie closer than he could othertuse coms. Anothor wasen why hronotian is wrong is that it allows a hruan mind to cane betweon the Individual and Christ. Ary forn of mind control can only thwart God's purpose foz man. "Behold, I stand at the doar, and knok, will He wants to cane 2 in, but the heart must be free from other presences and valuntarlly opened to Hin.

God desires to bring men into direct relation with Hinsele. In al2 His dealing whth human beings llo recogaizes the princlple of personal, responstbi21.ty. He seeks to encouraga a sense of personal dependenee, and to impress the need of personel guriance. He desires to bring tho hunan into assoclation with the divine, that non may be transfonned into the divine 21 keness. 12

Christ, not a humen boing, is the source of mind healing. In HLan aro prowidod great resources of thought that aro life-giving in thatr Ampuence.

Those whose minds and bodios sre diseased are to bohold in Christ the restoror.. . . . Is they cooperate vith HIn, obeying the Lats of health, and gtriving fo porfect hollness in this fear, He wiri impart to than His Iile. 2

\section{vIIx. BRAZWASRIIC}

Even nore diabolicel than hypnotisn are the brainwashing practhees used on enery eaptives by the Communtsts during the recent World Wax.

A fantastie thing is happoning in our world. Today a man is no Longer punished for the erines he has in fact conntted. Now ho maty be compelied to confess to erimes that have been conjured up

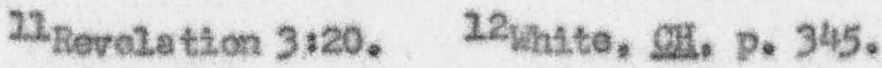

23 mate.. p. 346. 
by his Judges, who use his confesstion far politheel purposes. . . . We must understand that inpeis the false adnission of guilti we zust take another look at the human mind in all Its frenty and

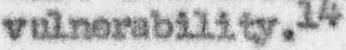

Broinwashing is vietous; Upon furet hearing of 1t, the United

States condermed Its vietins without morcy. At prosent there seess to

be wonewhat more lentent attitude toward these men.

To the horrorg the accusad viotin auffors from whthout must be added the horrors from vithin. He is pursued by the unstesdinoss of his own mind, which cannot aluays produce the sane mensuor to a repeated question. As a human being with a oonscience ho lis pux-

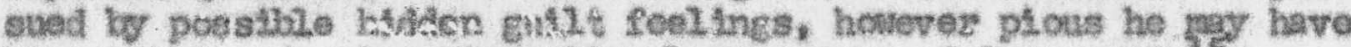
been, that undornino his ratlonal atuaronoss of innocenee. 25

If the pristoner"s mind proves too resistant, narcotics are given to eorfuse It: mesealine, marthuana, morphine, barbiturates, aleohal. If his body collapees before his nind eaptitulates, he recelves stimilants: bensedrine, caffetre, corantne, all of which halp to proserve his consetousness until, ho confesses. 16

Strong personalittes ean tolerate physteal agory; often it servas to increase stubbom resistance. No matter what the constifution of the victin, physical torture finally leads to a protective loss of conselousnoss. But to withstand nental torture leading to ereoping montal breakdown densinds an even stronger personslity. ${ }^{17}$

One prisoner testifties, "The words were mine . . . but the thoughts were theirs. That is the hardest thing $I$ have to explaint hov a man can sit down and write out sorvthing he knows is false, and

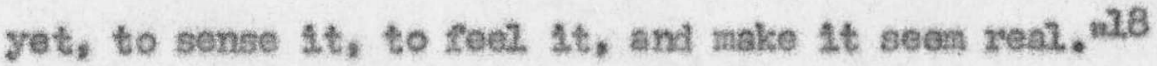

D5. Neerloo explains the techniques in his book. They are

$$
\begin{aligned}
& \text { 14heorloo, one att.; p. } 19 . \\
& \text { 15 Trosd. . p. 29. 26 Motd. , p. } 30 . \\
& 27 \text { mad.. p. } 27 . \quad 18_{\text {mad. }} \text { p. } 20 \text {. }
\end{aligned}
$$


torture, hanger, drugs, pergistent ropot1tion, mental eond1t loning. The ways in which they are used are most effective, Rornidable, and pxacticalig irresiatible.

In the Rasdes's Dicest of July, 1955, there is the story of John Hays, an Ansrican Protestant missionary in Chins, and hls experAence with bratnwashing. His vas the typtenl woarwdown. He was Iocked In a savil roon with very Inadequate fook, no books, frocuent questionIngs which he mast answay with no explanation, and his answers were frequently mistntorpretod, as he was not allowed to speak in Chineso, This was continued until, he was at the breaking point. He felt reacy to confess arything. The Connumists made ham a final offer, but John Hays spent the night before his find, answor in prayer. To hin was fulfinled the prontae, "I why. give you a mouth of wisdom, which an

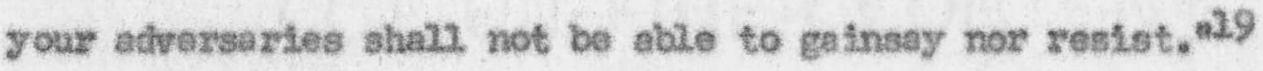

The next day betore his judges, he corrected his interpreter, and was then allowed to speak in Chinese on his own beholf. Mo was a fasclnating speaker, and as be explatned his true position they IIstened. IIe was Led beck to his cell, without lnowing his fato, but eventualy they roleased hin to return to Ameriea, and five of his jud ges wero exsecuted. 20

19 Lutice 21:215.

207rederio Scndern, Jx", "The Brolnwashing of John Hays, "The Beadex'a Draeat, Jutu, 2955, pp, 27-32. 


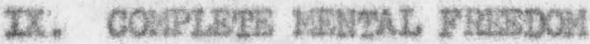

Caxi. Rogers, in his nondirective counseling techniques, goes to the extrerse in avolding Invasion of the client's mind. The personal. sorth of the Individual, and his huran digntty, are valued, The counselos respects the cllent's right to self-diroction and his capack ty to work out his problene. Thus Nogers sees the counsalox"s rale as ore of empethy and clarifleatlon.

It has also been nd experlence that the more deeply he rellies upon the strongth and potentlality of the cilent, the mose deoply does he discover that strength. It has seessed elear, fron our clinical experience as well, as our research, that when tho counsoloy perceives and accepts the ellent as he 25 , when he Inys aside all evaluations and enters inte the perceptual frame of reference of the dilent, be froes the elient to excplore his lile experlences anew, froes him to porceive in that exportence nev meanfings and nov goals. . . . To me Lt appears that only as the theraplst is corpletely willing that ary outcone, ary dixection, ray bo chosen-only then does he zealive the vita?, strength of the capagity and potentielsty of the individual for construetive astlon. 22

\section{z. RARAPSTCHOLDOCY}

Considexable contemporaxy interest is directed to parapsychology. The term refers to extrasensory experience. There are a rumber of beliefs to which the word applies. Spixituallsm, telepathy, extstenthalisa, and even orthodox Chrlstientt all have appliestlons of parepsychology. Tho onotlonal, expoxionees of corta in religlous denoninations, the roports of ChrLetlans" seeIng their decessed Iored ones, the 
82.

"Div Ine encountor" of the existential.2sts, all belong to the realn of parapsychologr. But parapsychology is not a phenononon originating

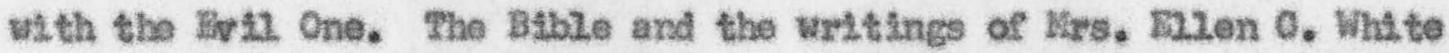
give maxy examples of the extrasensory. Cod speaks to the husan heart with a volice not andible. "And thine ears shall hear a word bohind thee, saying, This is the way, welk ge in $1 t$, when ye turn to the right hand, and when ye turn to the Iaft, "a22 has nothing to do with the nexves of hearing. "When Christ ascended to heaven, the sense of Ils presence was stiul with His fallowers. It was a personal presence, full of Love and 2Aght, "23 "llencezorth through the Splrit, Chrtst was to ablde continualiy in the hearts of Has ohildren. Their union with Hin was elosey than when lio was personally whth then, ${ }^{\text {2h }}$

A modern explanation of Christien paxapsyohology is given by Dr. Emest Whates

How does tho Spirit gutde men into truth' It seens to me that Ho works through the nornal mental processes of the indir Ldual. He works through the inteliligence and the exotlonal 14.2e with which He has endowed us. The Christian is called upon to use to the furl. the processes of reasoning and eapaetty for Judignent which Cod has given him: but these alone are not suiflelent. The Spirit operates at a deeper level, the level of the uneonsalous. Sonething more than an intellectual prechss is Irvalved. There is a process of spiritual enlightennent originating above and beyond rosen and manifosting itsole in spiritual intuition. This intuition is not the result of 2ogleal. rassoning. It cones in a flash, we harchy know whenee. It way cone in the slience when we are alons whth

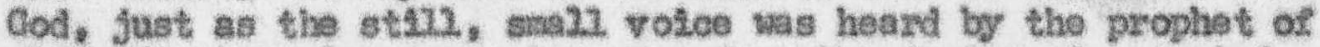
Qld. It rises into conselousness fron the depths of our ninds, and wo inooy. We axo mothorted to give a reason for the hope that is in us, but we did not aequire that hope simpiy on logicsi or motional.

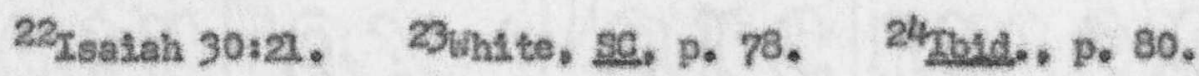


Erounds. Belfer often cones not as the result of reasoning about things but by a process which cannot be accounted for solely on conselous grounds. Truth about splrituel. things is of ten perceived by spirstual intuitton quite apart fron intellectual reasoning, the spirit in its depths cones into contact with the Spirit of God.25

There are wamings to be observed in the interpretation of this experlence. One is to beware of lingressions, and another is to be earotul of the value placed on night of fealing.

\section{XI. concuston}

There are wary wind rolationships that are necessary and benefletal. One cannot escape Intunence, and when the best to chosen, it can only prove a blessing. There are other relationships that are constantly or Interrattently present, but that caII for individual adjustmont to then, such as the appeal of modern advertising, or the pressure of a persuasive salesman. Domination, Lypnotisn, brainwashing, when exployed to Irvade the human mind go beyond what is morally xight.

The nee of medieine, and even hydrotherapy, in the trea tment of disease is accomplished through the brain and the nervous aysten in much of its applice tion.

Faraperyohology is another axes of mind relations, and there is both right and wrong in the application of this seienee. The work of the Hoiry Spirit is as rach parapsychalogy as is Splritualtom, but the first originated with hoaven and the second with an evil. spirit. ${ }^{26}$

25. ${ }^{26}$ See Appendisc 0 for further msterial on this chapter. 


\section{CLAPTER Ix}

BODX AWD KTHD

Daphasts needs to be placed upon the body and mind conbination as well as on the mind and body relattonship. There axe as mary tlinos when the body produces effects on the mind, as tines when the mand reproduces Its activities in boty response. "Itand an body" and "body on mand" are both statements found in the writings of Mrs. Whate. That this aspect is really important is recognised thuss "The body is the oniy medium through which the mind and soul are developed for the upbualding of character, ${ }^{\mathrm{el}}$

The Bible also recognizes the Importancs of the boty apon the mind. The Apostle Paul, mentions the boty rirst and thon the mind aftexwards when he writes to the Romanes "I beseech you thorefore, brethren, by the moxeles of Cod, that ye present your bodtes a Itving sacririce, holy, acceptable unto Hod, which is your roasonatile sorvice," Then he adds, "But be ye trensforred, by the ronewing of your mind, $n^{2}$

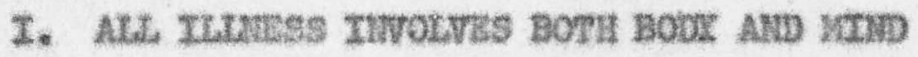

Ho one is 411 without the Irwolvemont of the mind, even an a predontnatingly body situation. Fover aristng from an frifoetion brings on delifrum, The Comunists and Nasts tortured the body to gatin eontrol of the mind.

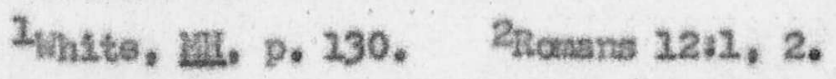


Thero is montal adjustnent to make even to a bed cold. There axe things aryone would rather do than spend a day or so in bed, or even be about in disconfort. Paln always involves montal tolerence. The restritetlons of diet, bed rest, disagreeable trea tnents, the prostrattion, the physteal inadequecy, all totel up In mental attitudes and saental, as well ss plysteal, disconfort.

There are always uncertalnt1es encerning outcomes, how long, hos nuch disablitivy, the disturbance of the IIving patterns, the uxge of responstbillthes, prospects of galns that must bo relinquished-aiz these ean aceanpany acute, as wall as charonic, 12zness. The despondoncy, the Irritabizity sutferod, the restlessmass, the Irearnia, the stage When the patient $1 \mathrm{~s}$ too 217 to caro, and the time of convalescence with its restrietions, bosedon, and worrios, its languos and exhaustlon, all. thase are margtnal products of physteal nilness.

\section{II. chotre prstass}

Acute disease may be quiclis forgotten. Sut ehronie diseases, such as dlabetes, haart disease, rheunstie fover, canear, and tuberekLosis eali for a reorlentation of the patient's 11fe. Thare is the Inttial aphoaval of adjustment-the lettige go of 14fe as th has been lmown bofore, giving up hopes and ambstions, roarrangting finances, and surrendering independenoo, completaly In some Instances, or to a lesser degree in others. There is always the conslderation of the future, sonetimea doubteul, and at other timas nore certala than hopaful. Eech disease w112 have Its oun reactlons, and these w111 be 
modifted by the Individuality of the sufferer. Diabetios know that thoy heve a Iifetime of restrictad diet, of soolal Interference and job adjustrent. It Is also lenown that the disease gives at least sone roduction to life expeetancy. To sceopt all this requiros constderable fortstude and grace.

Tuberoulosis attaoks the most productive years, firteen to thirty-five years, when the victim is just ready to live or is onterIng the helght of has caroer. Then to glve ono or two preetous yoars of productivity to bed rest, folloved by more years of care and unoertatnty oven after a successful curo, is hard to accept.

Cancer usully strikes $2 a$ tor in 1 ife, but Its hopelessmess is more certain, Its pain more diffloult to endure. One cancor patient nay conati suicide, feeling that it is the kindest thing to do to relleve Lored ones of the long nonths of care and watehing. Another

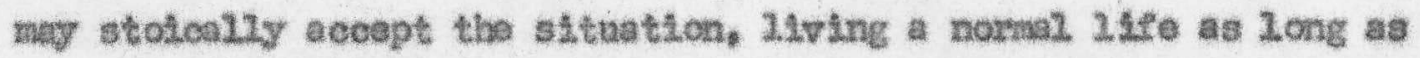
posstble, and keeplng up a happ front beesuse $1 t$ is the best for all concemed. Others mey beccuse fretful and unhapw, although this is not espectal2y characteristic of eancer.

There are conpensations in Lessons Leamed and values galned from MInoss that axe avallable from no other source. Surferting can perfect character or reveal 1ts weatmess.

\section{III. mavarze mumes}

Whon tho boly has been damaged or disf igured by aesidents, all the enotians and adjustinents that ean go whth ehronic sulness wust be 
made, plus the adjustment to visible disfigurement or perwanent handicap. Then the Iong straight road aliead ean be very dark. Orten there are feclings of infertority to whoh the alnd has a big task to adjust. The mind is eapable of making the body 211. but when the body makes the mind surfer, the suffering ean be Intense. The erippled, the disfligured, the handicapped all have to cultzvate courage. There are those who do Leam that 119e ataly belongs to them, and that they bolong to 218 and st112. have a contribution to weike.

\section{IV. conctusroli}

Nind and body cen form one combinat2on, and body and mind sts.21 another. Mental roaetlons to bodLly disease or injury ean be paInful. and durfleult, but 14Fe, with all 1te many posstbilitles, st121 balongs to al2. Even surfering has its corpensations in fortitude and understanding, 


\section{GIAPRe: $\mathrm{X}$}

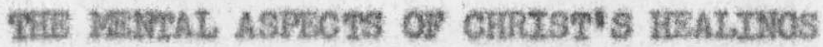

Jesus was prepated by porsongl, experitence for His Itfo vork of desting whth sin and suffexing. One elenent whth which the dealt was gud2t. During the Iong yesrs before He cans to earth, and ever atnea as well, gutlt has been ovadad In human philosophy. Both in His possond. expertence axd In the approach Ho made to Has misston. His work is unigue and sympathathe.

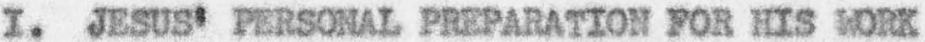

Even during His chlidhood, Jesus was 2 esmlng underetwnding and symgatiny.

During au. these secltuded years tis $11 f$ llowed out in currents of symeetty and helpfulnass. Iils unselelshness and patlont eniluranee, His courege and falthfulness, His resitetance to temptation, His mfatling poace and qutst joffulnoss, were a constant Inspiration. He brought a pure, sweet atnosphore Into the hone,

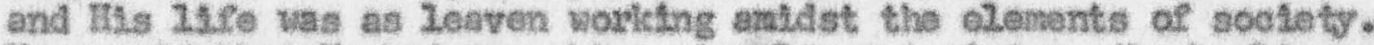

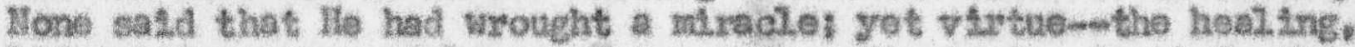
14to-giving poiser of Iove-jemt out from IItn to the teapted, the stek, and the disheartened. 2

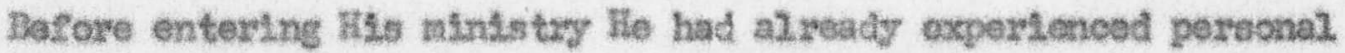
suffertng. In the wildemess of tomptatisn He had suffered human agory.

His human noture shranic Irom the confllot that awattec Wint. Wor forty daya Hé fasted and prayed. Heak and emaclated fron hunger, wosn and haggard with mental agory, "hlis vigage was so marwod more than ary man, and His forw more thm the sons of man,

\footnotetext{
Whate, uㅐ, p. 350 .

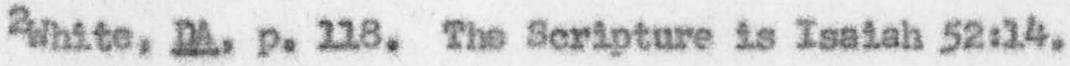


After the foo had departed, Jesus foll exhausted to the earth, wh the pellar of death upon His face. The angels of hoeven had watched the connlat, beholding theIr loved Comander as He passed through Inexpressible suffering to make a way of escape for us. Lis had andured the test, groater than wo shall cros be called to endure. The angels now ministered to the Son of Cod, as the Lay like ane ding.?

Tharowaro many tânes, no doubt, when human sucfering was again felt by Hin. In Gealing with Judas, Hrs. White brings out this Liea. "Day after day, when the buxden 2ay boaviest upon thas oun heart, Hie had borne the pain of contirual contaet with that stubborn, suspicious, brooding splest: " $^{4}$

Jesus wept at Lasarus" grove the shook with sorrow as fle vioved Joruselen and realizad Its not-too-distant fate. No actual plysical. disease could touch His boty, for He Iived in steh porfect accord with the Laws of 2.120, but He dId suffer mental reactions which expresed thenselves in IHis phrstcal. being. He was "a man of sorrous, and acqualnted with grief," that lib might bear "our grleis," and cary "our eorrows." "15 woz we bave not an high priest which cannot be tonched with the feelings of our infimatios, ${ }^{* 6}$

\section{Ix. CUIIS AND HEALITO}

"There is a divinely appolnted connection between six and atsease, $" 7$ The surfertngs of Jesus testify that Ho, though ininooent;

\section{3rbid.: p. 232. 4hite, Ed., p. 92. \\ 5 Isalah $53: 3,4,6$ Hebrews $4: 15$. \\ Whate, 52. De thes}


was sharine with mankind the ponelty of sin. And His hoolings often dealt with gurat and sin. The rostoration that christ grantod of ten Ineluded the forgtrenoss of sin. The Bthle Instruotion to the ehweh of the Cospel disponsatsion Ineludes forgiveness with divine healing. "Is any slek anone yout Let hin call for the elders of the chureht and Let then prey over hin, anointing him with of in the name of the Lord: end tho prayer of fulth shall save tho slok, and the Lord sha11 ratse hin ups and If he have comitted sins, they thall be forgiven him, "8 It might be proper2y qquest2oned, How does the forgtrenoss of sin flemre in mireculous hoaling as It is procticod at the present time? And 2 cotild be answered that man, In place of seeking forgtveness, hare sought out warv, many ways of Ignoring guilt. Thero were gods anone the anelents: wicked gods, 2 mexoral gods, bonign gods, vague gods, farmawey gods, and ovin an "Unlmown lod." In the worship of those gods thero was no recognition of guilt and no forctveness of sin. The Apostle Faul was acqualnted with Creek philosoply, and It is Paul's writinge that treat more thoroughy and directly the subject of conselenee than do the workes of ary other Blbie uxt ter.?

There have been mary systens of philosoply. and ethites In Iater tinas, and in none of them, except the lebren-Christlan system, is gualt adnitted and completely eured. listionallsm, the descendant of Greek philosophy, reasonod its way through on Ats own power-making the

\footnotetext{
$8_{\text {Jamos }} 5: 24-15$.

${ }^{9}$ Conl. F: H. Henry, Ghrietian Rersmal Ethies, p. 514.
} 
huran mind ulthmate. Natuxalien, of which Fantheian is one forra, disseminates Cod through all nature, as an all-pervading good. Nan, thus, includes hinself as a part of Cod, There are several forns of Hodonisat the Grrentes with tholy goal of pleasure for the present, the Eptcureans, who atmad more realistleally at what wonld give the nost pleasure In the 2ong zun, Jereny Bentham and John Stewart K122, wont so far as to

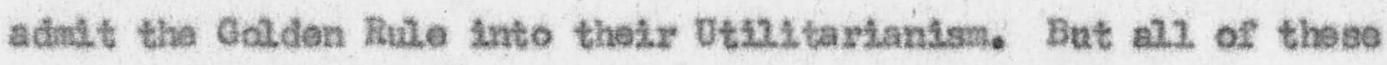
Ignored the Bikle teaching of guizt and restitution. Autong the political. Ioturaliats, gunit is the farthest renored in their theory that might makes right. Metzsche ereated the supeman and Karl Narx was the exponant of modem Soclalism, Kant, who taught a kind of morality In the form of what man ought to do, conceived of no atn and no guilit. Cuxit IInds no place in the theory of striet evolution, for man is beconing bettoy and better according to that teaching. The Progratism of Joln Dewey, slso apposing in nary other forms of phizosophy, makos richt dependent upon experienee and eustom thus moral standards becone Roxtbie and relative. When all ethiecl reference is depteted as morely fint to and relative, the notion of deeisive condennation rust be swept away, ${ }^{\text {eto }}$

The existentialista gainsay guil, when they accopt as the onily revelation a personal disclosure of God. Calvintstio deternintsm wealkons guilt. The Roman Catholie Church lessens gulzt in its coniesston to a huan being, in the doctrine of penanes, and in the elatm to have 
92

changed the Ten Commandnents. Thus man in a hundrod ways evade guilt. They are pleasure-tad: thoy are absorbed in getting galng they create thois om moral. world. Mon, in their effort to 1gnowe gunzt, degrsde man to the level. of a highly developed antuml, or, on the other hand, eleva to thoir own canpetence to diantss the need of Cod. Non exreuse guntt, they rationalize 1 t away, and they blante othors for their gull. They take every way but the right way, 12

Consetonoe, in contarporary 21fe, is a foundling. Its patomlty

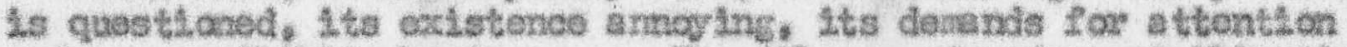
and responetbilit ty buxiensome. The d2zerma of modern olvilisation could indeed stem from the faslixe of incluontsal thinkors to support the Christian view of conselence. Modom thought, in, fum, guite esafly relegates the foundling to complete abandonnent. 12

The worid of hunan deolsion and relations is a fallen world in rovelt agatnat the holy winl of the Creator-Cod, The smage of Cod is sullied. Nan is a morsi, rebel. who is threatoned with Divino wrat th.

This fundarentel prentses places the Christian Interpretation of

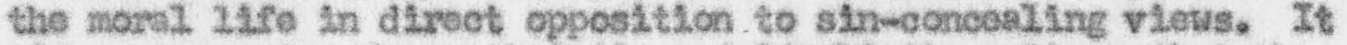
EIves no guurtoz to panthatstie and Idealistic notions that the whole of reals.ty is made up of an indestruetzble good. Bibliealy revealed ethios disntsses as shallow all evaluations of the ethLeal. sttuatien which besitate to v1ew aln, desth, and Satan as dotenatrative categorles. Foletence of depthiess v lows of the norvi predicament in sin would only give birth to equal2y suporficinl viows of man's deliveranes. Christiandty eleariy pointo out the moral divoree of Cod and wan. Recorclliation is man's most desperate neeco 13

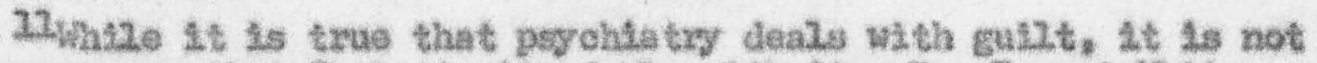

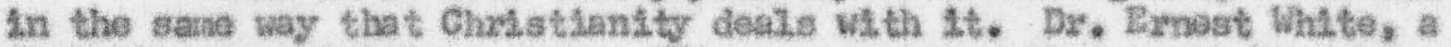
Christian psychtatrist, says: "It appeass to mo that psyehology has no satisfactory answoy to the probiem of gullt. It way bring rolies by

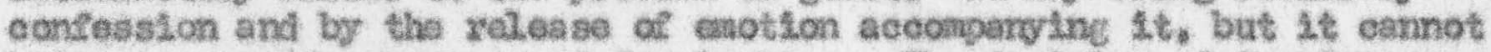
bring poece snd assurance of forglveness. The doctrine of forgtveness which christianity has to offor can snd does rid people of gulit and

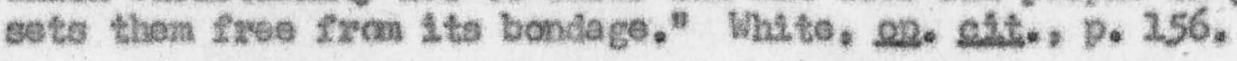

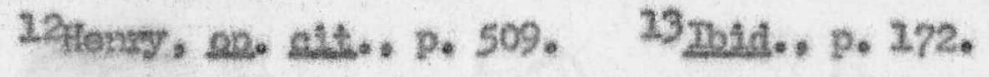


Jesus cane to seek and to save that which was 2ost* In HIs ministry He placed sin and gullt and conselence in tholy right relation to man's condition; and then He applied tho true renedy-lits oun salvathon. When He came He found that

The deception of etn had reached Its helght. AMI the ageneles for depreving the souls of men had been put In operatlon. The Son of Cod, Looking upon the world, behold surfering and misery. Whth pity Ile saw how mon had become vieting of Satanie cruelty. He Iocked with carnassion typon those who were being corrupted, murdered, and 2ost. Thoy had chosen a zuler who chalned then to his car as captives. Bowizdered and deceived, they were moving on in eloory procasslon tovard etemal ruin--to death in which therv is no hope of Iife, towa rat night to which cones no moming. Satanie agoncles were ineorporated whth nen. The bodies of hunan beings, wado for the dwelling-place of Cod, had becons the habitation of denons. Tho sensss, the nerves, the passlons, the organs of men, were worked by supernatural agencies in the Indvi gence of the villest lust. The very stamp of denons was Impressed upon the countenanees of men. Human faces reflected the expression of the Legtons of evil with whlch they were possessod. Such was the prospeet upon which the world $d^{3}$ s fedeener 2ooked. What a spectacle for In'tnite Purlty to behold !4

This was the pleture of gullt thst faced tho Son of llan as Ho took upon Hinself man's restoration. "By His humanity Christ touched hunantty: by His divinity, He Lays hold upon the throne of Cod, n15

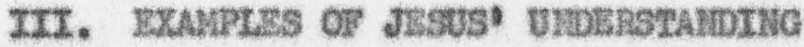

"The Savlour made oach work of hosling an oceaslon for teplantang divine prinetples in the mind and soth. "16. A22 of His hoaling was a ministry to both mind and body, an occasion to reach the soul.

$$
\begin{aligned}
& \text { 24hute, DA, p. 36, 25 Mhid.. p. } 24 . \\
& \text { 26.hte, as, p. } 20 \text {. }
\end{aligned}
$$


Thyee adulterous wonnon are recorded as having roeaived hoaling fron Josus-the wonan of Semaria, Nary Nagdalene, and the wonan taken In adultery. For these woson Christ had no eondemnation. He Ied then to see tholy sin and to accopt restoration.

Wherevior there exlsted a sense of need, there He varu opportunt ty for uplifting. Souls terpted, dofea tad, feeling thorseives Ioet, zoady to perish, He met, not with denunctation, but with blosaing.

In erery humen being lio discorned infinite poselbizities, . . . Looking upon thom with hopo, Hio Inspired hope. Heeting them vith conflidence, He inspired trust. 1 ?

These aro examples of 11 s greatost maracles. "In tho uplifting of this fallen soul [the wonan taken in adultery], Jesus pertorned a greater miracle than in hoaling the most gxiovous disease." 28

Vayy Nagdaleno had been dellvered from seven dev2lis, and at another time in Chrtest's mintstry He healed two madinen at Cadara from denons that called thenselves "Logtan." Whan the ev12 spirits 2eft them, Jesus spont a 11ttle time with thax, The swinekeopers, whose herds received the devils and plunged inte the sea, had gone to the elts and returned with some of the populace, who requestod Jesus to Leave thats territory.

Not onily was this a hoaling of afrd and boty, but Jesus went even farther and prorided for the 2 rehebilitation in the telling of their exporlence to thelr own people. The healing of the danonlaes

$$
\begin{aligned}
& \text { 27whte, Bd. pp. 79-80. } \\
& \text { 16. Whte, DA, p. } 462 \text {. }
\end{aligned}
$$


hed occurred early in the morning, and that sane day Jesus recrossed the Iake, and found on the opposite shore a multitude to receive Hin. After toaching and healing for a tine, He left to attend a feast at the hors of Lev1 Hatthew. It was while at Matthew's home that Ha was found by Jalrus, who came to IIm from the death chamber of his 1ittle daughter. On the way to Jalrus" home Jesus eneountered a wonan who had been 112 twelve years. No plystelan could belp her. A 11ttle eonstderation reveals more than is directly stated in the sumple narrative. This wonan, according to the eeremonlel. 2aw, was unclean, 19 She right not attend the synagogue, but she had heard of Jesus and IIs many miracles, and coneluded that if she could but touch the ham of His garment, she would be cured. Iven this she was ceremonialiy forbldden to do, but she must have heard how Ho willingly touched even lepers. Luke tells the story from the standpoint of a phystelan. He strosses the hopelessness of the case and her economte benkruptey. It is Mark who includes the fact that she had suffered many things of many plysiclons, While she only grew worse. Luke did not Implicate his feliow physietans. He Justified them with the hopelessness of the ease.

If this wenan were treated by present-day wothods, she wovld be given a blood-bullding diet, put on mediestions that would orereone hey anemia, and probably some endocrine preparation would be preserlbed. elong with some potent vitamins. She would be given blood transfusions, and surgery probably would complete the cure. Instead of her beIng

\section{9 zevitieus 15.}


constdered a sinner, her frtends vould visit her in the hospltal, her roon wovid be filled with loving offeyings of nowers, and hor husband would pay the bi2l. There wotld be no 2 one years of hopelessness and Ionoliness. But these methods, too, are outecues of the love that Jesus shad an this dark, sintul world.

But in Jesus" time a wonon 2 lte thls stin had wore problens. According to the rabbintaal. Iav she was divorced from hex husband. She vas stignatiecd by soctety, and she was a sinnor. But Josus mot these problems too, and prorlded for her rohabliltation by giving her hope and conflidenoe. She wowld nover forget the monent when His power

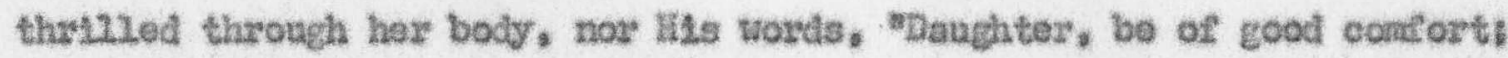
thy falth hath made thee whole. "20

In the meantimo Jairus was walting. The condition of his daughter was exitieal. When ho left hose to flnd Josus, she was at the polnt of death. Jesus had started promptry, but He wes dolayed by the crowd and thon by this woman. A messengor brings the nows that the chald is dead, and adde the suggestLon, "Trouble not the Kaster." But Jesus preased on and raached the deathbed of the 1 ittle gar2.

Then He spoke, and satd, "Malden, arlse," That may be, in sorro senses, perfoctly accurate translation, and yet, as a matter of fact, it has missed something of infinite beauty. Mark tellis us that He sald, "Tralitha ount." Now that is not Creok; 1t lo not Hitbrow, but it is Axana $1 \mathrm{c}$. It was the language almost unquestionably of His hone, the conmon language of the connton falk, in the connon things of 1ife. We render the saying with supposed dagnity as "Damsel, arise." Let as look at it a ilttle carofuny. The 
word, "Tolitha," is diminutive. It moans "Little lanb," It was a word of infintite Love and tenderness. We are Looking and 2istenting, and we see Cod mantest in the Mosh pat wis hand, the hand that gutdes and governs the movenent of ali worlds, upon the dead hand

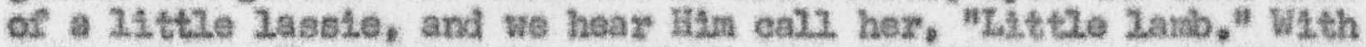
thls eddreses Fle uttered the word of authoritative cormand, "Arise, "2L.

When the child opened her oyes, whole and well, Jesus presented her to her parents, and renenbered her Lrunedlate need. He told them to give hey somethling to eat.

When sin ontored the world, gutlt figured in the destruetion of the phrsical powars, and In Christ's healings there were those whose Iives were haunted by the conscioneness of sin. To these espeeially, Jesus was a messenger of mexcy, not only whth healing, but with the assuranee of sins forghtren. The paralytite let down from the rooftop. the man healed at the Pool. of Bethesda, the Lepers, whose very disease was a syzbol. of $\mathrm{stn}$, the dev12-possessed, Impotent oven to request hesling from Him-all these were hoolod of sin as well as of discase. Jesus' hoalinge could make mon thole.

\section{ConcLuszow}

To make His ministry effective, Christ Hinself had undergone sufforing in the wilderness, and thore are nany ovldiences reeorded of an Innoy 2.1fe of enotionol keonness, Jesus' work was unique, because He went to the root of disease, back to 1ts original cause as Lt came about in Eden. He ministered to the whole being-body, mind, and soul.

23. Carpbell Worgan, The Great Burstotan, pp. 166-67. 
He enterod Into the whole eireunstances, sonetires Ineluding a measure of rehabilitatlon. There were vide impliteations in His manistry. Sin hed roachod Its 2 inits; Satan clalnod both mind and body in the diseases he Inposed upon men. His viotins were so hopelessiy entangled that oniy dirine power could break through and set them free.

How differont axe Jasus' nothods and Whs understandings fron those of the ereatest hunan atnds ! Outside Christiant ty man's efforts at gaining the bost $2 \mathrm{n}$ moatal minlotxy are to find a way around 1 ts ceusemaln and gullt. The gontle worda of Jesus forgave sin and clesnsed the soul. Miary are suffexing from the maladiss of the soul. more then from diseases of tho body, and thoy find no relief until they cons to Christ, the wellspring of $21 f e, 0^{n 22}$ The same forglveness and tho same elewsing are stin avollable in Hin.

22. White, The Zasth 2 Luze Rx, p. 99. 


\section{CHAPTSR XI}

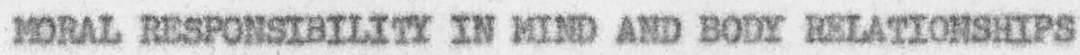

Macing moral respons2b12ity for mind-body relatlonships end their outcones Invalves a Iarge number of factors such as the

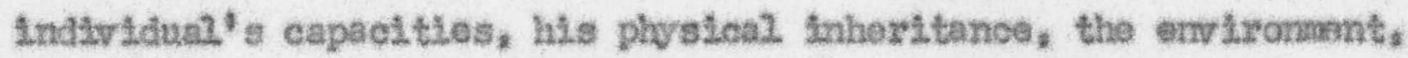
and the denands made upen ham.

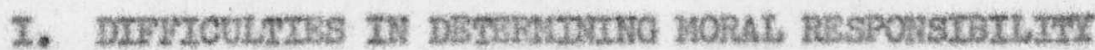

Whon ChrLet hoaled a man bom bi2nd, H1s dischples aeleod Him who had sinned, this man or his parents, Jesus pleced no responstb211ty. At turnes oven physlctans are unable to understand all the mochanisms of a Aisease. Causes are often difficult to search out. DF, Shryock says:

Thero is a fatrly large peresntage of cases of somalled "functional" or pxychogente dissase, howover, in which it is difflevil. II not impossibie, to discorer any emoticnal factor which seens to herve been responstble for the production of the disease. The disease itself is the type which resulta from ar inbelanes of the autonomic nervous system but inquiry into the patient's histoxy falls to roveal a procipitating enotional feotor. It may be properiy assumed in these cases thet, for one resson or another, the lypothalarus ls functioning abnormaliy. 1

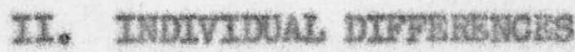

Individual differences are recognized in montal ability. plyetcal, appearance, wechanical performance, and in all other areas

\section{eocrephed.)}

Illarold Shryoek, H,D., "Psyohoblalogy," Chap, 2, D. 20. (Mam- 
of huran abllity and behavior, and these too are to be taken into consideration in moral responsibility.

Jesus, our advocate, is acqualnted with all the cireusustances wh th which we are surrounded, and deels with us according to the light we have had, and the elrcumstanees in which we are placed. Sone have a much better organization than others. While some are continualiy harassed, afrlicted, and in trouble, beeause of their unhappy tratts of eharecter, hoving to war with internal fous and the corruption of their nature, others have not half so zuch to battle against. They pass along almost free from difficulties which their brethren and sisters who are not so fevorebly organized. are laboring under. In very wany eases they do not labor half so hard to overcone and live the life of a Christian as do sone of those unfortunate ones I have mentioned. The latter appear to disadvantage alnost every time, while the former appear much better, because it is natural for them so to do. They way not labor hale so hard to wateh and keep the body under, yot at the same time they compare thelr lives with the lives of others who are unfortunately organized and badly educated, end Ilatter themselves with the contrast. 2

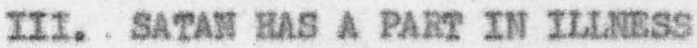

The enery is to be reckoned with in aceounting for 1uness. Even the White famlly suffered L11neas and death. Mrs. White herself was of ten asflieted. Clod allowed Job to surfer, and he 18 deseribed as a perfect man.

I saw thet the enery w12. eontend e1ther for the usefulnsss or the 114e of the godly, and w111 try to maz their pesce as long as they 12ve in this world. But his power is 1.1mited. He may cause the fumace to be heated, but Jesus and angels will watch the trusting Christian that nothine may be consumed but the dross. The fure kgndled by Satan ean have no power to destroy or hurt the true metal. 3

Death is the sentence pronounced upon all humankind. As long as

$$
\text { Whtte, 22, pp. 74-75. Shite, 12. p. } 309 .
$$


there is sin there will be death, and if death, thore will be slekness, and in all sickness the mental state is a part. Either sonatic or psychosomatio disease can be a hereditary potential; both can cone about through Ignoranee, as well as willful disregard of natural 2 aw. In a world full of sin, disease and desth must exist.

The Christlan who manifests patlence snd cheeriulness under bereavement and suffering, who meets oven death 1tself with the poace and calmness of an unwavering faith, may acconplish for the gospel more than he could have effected by a long life of falthelu. Labor.

\section{STATUS OF WORAL RESPONSTBILTTE}

Whet, then, is the real, status of woral responsibility? Should It not consist of what it is posstble for one to know to provent both organie and psychosonatie disesse? Surely it is clarifled in the fallowIng statement by Mrs. White:

They [men and wemen] need to be impressed with the fact that all their powers of mind ant body are the gift of Cod, and are to be preserved in the best possible condition for service.?

Life is a haly trust, which Cod alone can enable us to keep, and to use to His gloxy. But Ho who formed the wonderful strueture of the body will take specisl care to kep it in order If men wi.l. not work at exoss-purposes with HAm.

Dr, Raynond 1512 says, Miso, indeed, is the man who understands thst he is a hyperparasympathetie nervous system resetor." In further developing the subject he goes on to explain:

In the lyperparasymathetie reactor the mental adaptation to emirormental stress and strain, whether real or imaginary, causes

\footnotetext{
4hite, the Acts of the Anorties, p. 465. Shite, 19, p. 230. Ghite, 6x, p. 379.
} 
the stomach to secrete digestive juices, inerease its blood supply, and go into muscular spasmis, though no food is in the stomsch. Because this is a disturbance of the autonatic controli.ing nechantsm, it is not under voluntary mental control, hence the produetion of stomech syratcons, whether he wants them or not. . . .

In ny opening pars graph I said, "WLe, Indeed, is the man who understande that he is a hyperparasympathetic nervous systen reactor." Mey I add: Wiser is he if he understands that it is not what happens, but his attitude toward $1 t$, that makes him leel the wey he feels. This is especialiy true in the production of stenach w.cer, with its accompanying symptoms. Wisest is he if he understands that the development of a Chrietian charecter-with its hope. Its feith, its attitude touard adversity, its source of power, as characterized in the Semon on the mount-can modlify the reaction and goals of the Individual. who espouses it.

This fact is easy to talk about and relativeiy easy to understand--but hard to apply. Yet therein lies the real prevention of stomsch wlcers. Duliness of understanding necessitates the continued ase of drugs for symptonatic rellef. This elther sedates the brain to control, anvilety and tension, blocks the transmission of parasympathetic nerve impulses to the stomach to modify its function, or neutralizes the excessive output of gastric julces.?

Dr. Clarence Dale also explaLins morel responsibllity in nervous

conditions.

In conolusion, we can assert that nervousness can be avolded or correeted. Each one should snalyze his own situation and approseh It from the viexpoint of preventing causes and breaking the vielous cycles that are $1.1 \mathrm{kely}$ to ocour. Obviously, those who claim the divine promises for help in the meny distrgsses of itfe hive a great advantage in orereoming nervousness.8

It w21 be found, however, that, like sanetifleation, right mentel habits are "not the work of a monent, an hour, or a day," 9

Praynond HนL工, M.D., "vicers-a Diseese of Modern Life, RexteW and Hexald, Hay 27,1956, p. 28.

BClarence Dal.e, K,D., "Must I Be Nervous?" Reviev and Herald, June $2,1955, \mathrm{p}, 18$.

Thite, 2r, p. 340 . 


\section{v. WHEFS RESPOASIBILITY BECINS}

Gonsecration, or what is thought to be consecration, ean be made without a very vivid idea of the perts Imolved. Paul speaks of the "whole spirlt and soul and boty" being "preserved blameless, "10 In his letter to the Romans he admonishes them,

I beseech you therefore, brethren, by the nurcies of God, that ye present your bodies a living sacriflee, holy, scceptable unto God, whlch is your reasonable service. And be not conformed to this world but be ye transforned by the reneving of your mind, that ye may prove what is that good, and acceptable, and perleot. wi11 of God.11.

In speaking of consecration, 1ittle emphasis is placed, often, on the body. The w111, the heart, the intellect, are called for, but Paul puts the body in first place, alking it the vehicle of the mind.

These who put tholy trust in Christ are not to be ensleved by ary hareditary or cultivated hablt or tendency. Instead of being held in bondage to the 2 ower nature, they are to ruze every appetite and passion. 12

By steadfestly keaping the will on the Lord"s side, every enotion wixl be brought into captivity to the w112 of Jesus. You wi12 then $f$ ind your feet on solid rook. It will take, at times, every part1ele of willpower which you possess, but it is God that is working for you, and you will come forth from the molding process a vessel unto honor. 13

\section{VI. conctustons}

When drawing conciusions affecting moral responsibility, it must be recognized from the material presented in this chapter, along with

$$
\begin{aligned}
& \text { 101. Thessalontans 5:23. 11 Romans } 22: 2,2 \text {. } \\
& \text { 12.hste, 배, p. } 175 . \quad 23 \text { White, 52, p. } 514 .
\end{aligned}
$$


what has been discussed in preceding ehapters, that meny factorg axe to be taken into conslderation. These are presented in the follouing eonelustons:

1. Ilunan beings are born with the capacity to make emotional responses. Before a in entered, these responses ministered to the happiness of mankind, but when sin added trials and sorrows, grief. anxiety, and guilt, man's nervous system was buxdened with new adjustmonts. These changes are necessarily felt by every human being, thus making possibilities of psychosona tie disease the nomal inhert tance of all. If death $1 \mathrm{~s}$ the "wagea of $\sin ,{ }^{14}$ then part of the wages of sin is siekness.

2. Koral responstbility nay be impossible to place as far as human understanding is concerned. Iven physlelans eannot always determine the cause of either psychosonatic or organic disease, Then, many hereditaxy faetors are Impossible to deal with. Even Christ did not place blame when Hlo healed the man who was bom blind. Although He knew the whole long train of causes and effects, He did not revesl it to His disciples when thoy aeked Him who had simed, the man or his parents.

3. Cood wen, 2lke Job, have suffered. "There was none like him In all the earth, a perfect and an upright masn."15 Even Chrtst, the Great Healer, was "a man of sorrows, and aequainted with grief, "16 and He oventually died a paychosonatie death.

$$
\text { 14teonans } 6: 23 \text {. 15job } 1: 8 \text {. 16 Isatah } 53: 3 .
$$


4. The mental element is conaon to all disease. Bven Christians esmnot escape it.

5. There are great variations among individualsm-sone with far mare sensitive nervous systems than othors, and thus more susceptrble to maladjustments and functlonal dLease.

6. Nany tenston-bearing situations are inovitable, awd may call. for more nervous stability than some individual possess, Sone persons, too, are called upon to bear, sbove others, wear and tear on the norvous system. There are times when leghtimate demands are ande upon individuals Which camnot be Ignored, even at the expense of physical damage.

7. Emsironnent plays a constant part in mental health, but the ear1y enviroruient, before the Individual, has developed the maturity to direct his own 1.49 , has alrosdy been most important in shaping the eapacity to deal with frustration.

8. It must be recognized that there are individual dieferences in moral. responsibil1ty. The information possessed, or the information possibie to gain, figures in moral responsibility.

9. In some minds there seems to be an element of stigna attached to mind-caused diseases, while the sufferer who violates natural. lows may be nore easily exeused, though he brings physical allments upon himself. Both have violated God ${ }^{*}$ laws, both are suefering, and both bear responsibility proportionate to their opportunities to lnow and to choose.

10. While there are sone causative factors that favor the developwent of psychoscnatic Lilnesses that are beyand the personal. 
responsibility of the one concerned, there are other contributing factore for which ho is responsible. Anong thesh are undus anxiety, worry, jealousy, and ali other forms of self-centeredness, whlch belong to the lone list of causes of neurotle diseases.

11. The Christian has resources beyond those which are known to those who do not have access to the power of Christ. It is the duty of the Christian to inelude his body as well as the will and intellect In his eonsecration to tod, and then he neod not carry a burden of guilt, Christ forgires his sins. The Christian way bring his problens to One whose Word is fllled with "exceeding greet and preclcus promises: that ye might becare partakers of the divine nature, having escaped the corruption that is in the world through lust. w17?

12. Bmotional growth is gradual; it takes a 11fetime to perfect, and there are poss1bilities past any human attainment. "All who would be workers for lod nust strive for perfoction of every orgen and quality of mind. 18

The love which Christ diffuses through the whole being is a vitalizing power. Ivery vital part- the brain, the heart, the norvesm-1t fouches with healing. By it the highest energles of the being are roused to activity. It frees the soul fron the gualt and forrou, the anxilety and care, that crush the Iffe forces. Whth It cone serenity and conposure. It inplants in the sous. Joy that nothing earthiy can destroy, $--j$ gy in the Foly Splrit, - -hoalth-giving. 11:0-giving joy. 19

272 Peter 1:4, 18,wite, cot, p. 330.

19whate, 1m, p. 225. 


\section{CHAPTEN XII}

SUwara AmD Rcomakndamons

\section{SUMARE}

1. Long before organie disease appeared, gui2t, anxlety, sorrow, and fear began to mbreak down the 11fe forces, and to Invite decay and death. 2 .

2. These enotional developments that had Introdueed physical bxeakdown to the huran race culminated In the death of Christ, a doath due to both aental, and physical suffering.

3. Imolved in wind and body are both plystologteal and psychological mechanisms. Particularly important are the nervous syston and the endocrine system. Among other things, health depands upon a balance between the sympathetic and paresymgathetic nervous systen funotioning. Cood funetioning of the endocrine glands is also a part of health.

4. Emotions are closely bound up with the autononic nervous sstem and are also related to the activities of the ondocrine glands. Emotional experiences alter both organic functlons and body chemistry.

5. Honeostasis or constancy of bod1ly integrity is essential. to phystcal wall-being. Too great or too long variations in this status gue becone serious or oven fatal.

6. There are certain constant psychol ogical needs-security.

IWhate, yB, po 242. 
love, self-esteem, self-realization. Cood ad,justment, personal happiness, and even physieal well-being are bound up in the fulfuliment of these needs, so that they becone physiological as well as psychological.

7. Even prenatal Iife is afrected by environnent, 1 inited as 14 1s. After birth the food the mother provides, the love and acceptance she gives, the very atmosphere in which the 1ittle one develops, are the responalbility of the mother above everyone else.

8. Before the chlld is eapable of ary moral nesponstbility of his ova, the parents have done wuch to form his conselence or superego -a vital part of the eht2d's moral discipline.

9. The kind of diseipline the home supplies-odirective diselpline, or discipline that is negligent, overindulgent, or domineeringw12. tell. on the future life of the chlld both mentally and physically. The hore influence goes farther than any later force brought to bear upon the child in the development of good ox poor adjustments.

10. As a chlid matures, more influonces a re brought into his 2ife. (a) The school and its teseher, playmates, and lesson material. (b) The level of the eulture in which he 1.1ves, with its mores.

His contact with religion and what it is made to moan to him. (d) La tex the job, with all Its agreeable and disagreeable features, its canpanionships, and the demands $1 t$ makes.

11. Envirorment never ceases to cast its influence on the lise. Wyen in old age there sre still enotionel needs to be met, still mind and body relationships which operate. Intellectual, emotionol, and spiritual growth ean continue to the end of 1.19e. 
12. A few diseases are hereditary, sone are prenatal, but moet are sequired. However, the type of constitution Inherited does much to deternine the future resistanee or susceptibility to certain diseases. Psyehoscmotic disease has to do with the balance between the two parts of the sutonomie nervous systers, the kind of endocrine system inherited and the constitutional adequacy of the Individual.

13. The capacity to learn is a provision that goes with the freedon of man. Leaming 2 s the result of environmont and the way it Is appropriated by the individual and those responstble for hin.

14. Aight thinicing is one source of resistance to disease, both plysiceal and psychogenze. If that which fizis the phonomenal fleld is selforeference in the form of anxietles, discontent, discouragenents, hurts, self-depreelation, resentments, there can be no wantal heal th. If in the field of reference there is objectivonoss, Inspiretion, kindly thoughts of othere, and above ali, a eonsciousnass of Christ's presence. there wมבI be montal health. Reformation in thinking may require deolston, time, diligence, but the endeavor is worthwhile. During the eariy Iife, parents can do ruch to help a child form good habits of thinklng. Happiness is particulariy important to a ehLld.

15. Wo one can escape influence, but when it becones poseessive 1t has exceeded its logitinate sphere. Radio, television, polities, advertising, salesmanship are continually assaulting the conselousness, and to be unaware of there pressures of mass media is to become their viotim. Donination is a form of mind contral, as are hypnotism and brainwashing. In the se Irvasions of the Individual's mental processes 
the moral $12 \mathrm{mit}$ has been exeeeded. Mind control is wrong because it Involves the w2ll; it gives human control the place that should be yielded to God. If another has the rind under his control, divine Innuences are erouded out.

16. Many drugs act on the norvous system. Their use calls for discrimination, especisily when they sot on the will or are potential. for dependence.

17. For the time of trouble yet to come, tools are already formed for mental torture and mind control. Then the promises will be nseded, "If ye drink any deadly thing, 1t w13s not hurt jou," ${ }^{\text {2 }}$ And surely the provises can be extended to the use of hypodermle polsons, even though they were not in existenoe when the premise was given. As with John Hays, when he was the vietin of the Chinese Commanists, Cod"s people can have vords given them when thoy must answer theil enemies. 28. The subject of parapsychology offers both wight and wrong uses. While the oxtrasensory can be concerned with SpLritualism, hypnosis, and other objectlonable bellofs, It also a pplies to the soul's relation to God.

19. In Christ's time sin and disease had resched a clinax. Christ not only healed disesse, but lle set in motion in?luences that have reached to the present tine. From Adan to Christ and from Christ to the present tame, gullt has Iigured in man's experience. Cullt is montelly uneonfortable. It is a contributing factor in plysieal 
disease. Nen have discovered thetr own ways of dealing with gullt, but they are 22logleal and Inelfectsve ways. When Chrtat eame, He recognired gullt as a causative factor in disease. He could say, "Co, and sin no more," and "Thy sins be forgivan." Even though sin was offenslve to HIm, and even though Re combined the forgiveness of sin with mery of His miracles of healing, Ho withheld condemnation Irom those with whon He dealt. He made them feel His help, not His disapproval.

20. The question of moral respons1bli1 ty in mind-caused dLeases has many fecets. There can be Antergretatlon, Individual. differences in responsibiltty, emiromental pressures, different opportunities for lmoviledge. As long as sin and death relgn there must be stekness. Nuch the same personal responsiblilty exists for orgenie disease as for psychosonat20 diseave. Etthey ono mey result fron orerwork, and whether the oreruork has precipltated a heart attack or a norvous breakdoun, the moral. responsibility is the same. Wrone eating has 1 ts mental offects, but whether Its results are prychosomatic or phyoleal disease in no vey lessens thoral, responatbility.

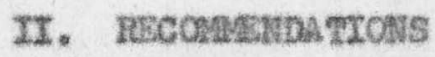

Besides the nore extensiva resos reh that could be done on the subject of mind and body, there are other areas of psychology which covid proflt by study of Mrs. Whito's writings. Sone of these might be 2 isted as fallows:

1. Child psychology. Present-day concepts would sind abundant 
corroboration in these writings. Some modifications might also appear.

2. Individual differences. Mental capacity is measured by I0 tests. There are scattered statements that clarify these concopts. These statements, if brought together, would make a profitable study.

3. Human relations. There is abundant material accesstble for the study of this toptc. Some 21luminating viewpoints on counsel.ing would also be diseovered in this cormection.

4. Psychology. This subject is Satan"s chosen way of onsnaring the last generations, aceording to Mrs, White. Diseovering the was In which he uses it to his advantage would make a worthwhile study. 
BTBLTOCRAPY 


\section{A. Boors}

Abbott. Coorgo Knapp, K.D., et al. Phvsteal Therapy In Nurglng Care. Third edition. Washington, D.C. Neview and Eerald Publishing Assoctation, 1945. $494 \mathrm{pp}$.

Alvarez, Walter C., M.D. Nexrourness, Inditeretion and Baln. Nev Xorks Pavi. B. Hober, Ine, Hedical Book Dapartment of Harper Bros., 2943. $488 \mathrm{pp}$.

Anthory, Catherine. Textbook, of Anetcry and Brstolock. Second editton. St. Louks: C. V. Mosby Co.. 1955. 672 pp.

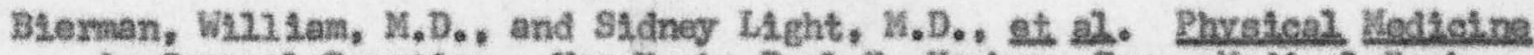
In Coneral Eractiee. Now York: Paul. B. Hoober, Inc., LedLeal Book Deportment of Alerper Bros., 1952. 798 pP.

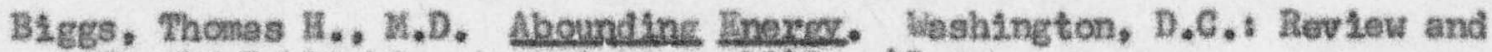
Herald Publishing Assostation, 1949, 43 pp.

Blanton, SmLloy, M.D. Lore or Rertsh. New York: Simon and Schuster. Inc. 2956. $227 \mathrm{pp}$.

Blungarten, A. S.. M.D. Textbook of Natexia Neding. Bhaxnacolory and Therapenties. Seventh ed1tion. Iles Iork: The Ka crillan Co.. 1937. 875 pp.

Britt, Stewert Henderson. Socind Rswcholory of Lodom LAfe. Revised edition. Nav Xorka Rlinehart and Co., Ine.. 1953.703 pp.

Cameron, Nowan. M.D. The Reveholosy of Bahevlor Disorders: A BLosoctal. Interpretat Lon. Cambridge: Houghton Mifnin, Riverside Press. 1947. 622 pp.

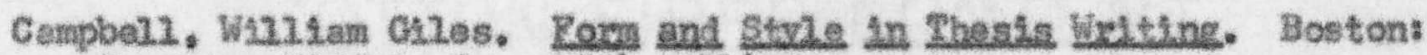
Houghton NLfRI in Co.. 1954. 114 pp.

Cec11, IitsseI2. L., M.D., et 2h. A Textbook of Medteine. Seventh edLtion. Thiladelphis: K. B. Ssunders C., $1947.2730 \mathrm{pp}$.

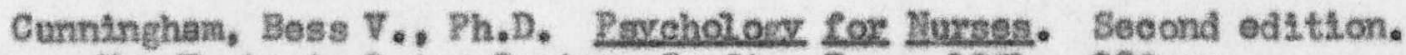

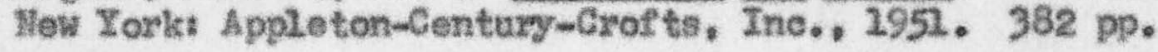

Dorland's Ilustrated Ledieal Dlotionow. Twenty-third edition. Philadelphia: W. B. Seunders Co., 2957. 1598 pp. 
English, Horace B., and Ava Chepney English, A Conorehongiva Dletionaxy of Erreholoricel and Reschoanalvticel Terns. New Xorks Longnans, Green and Co., 1958. 594 pp.

Henry, Carl 7. H., Ph.D. Ghristian Personel Ethies. Orand Raplds: Wh. B. Eexdmans Publishing Co. 2957.625 pp.

Hinsan, Frank, K,D. Drinciples and Practsee of Drolocy. Phtladelphla: V. B. Saunders Co., 1935. 2221 pp.

Kimber, Dians Clifford, A,Mo, R.M., et al. Textbook of Anatom and Bhyshologr. Thirteenth edition. New Yorkt The Nacmulian Co., 1956. $850 \mathrm{pp}$.

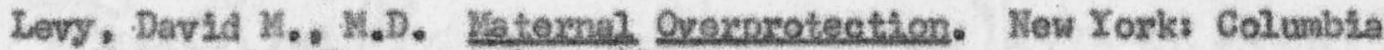
Untversity Press, 2943. 427 pp.

Na slow, A. Nev Yorks Harper Bros., 1951. 665 pp.

Noy, Rol20. The Sortings of Creathe Hivine: A Studv of Huinen Nature and lod. Wew Yorkt Abingdon Cokesbury Press, $2940.271 \mathrm{pp}$.

Neerlioo, Joost. A, M., M.D. The Have of the Hindi the Revcholocr of Thowelt Control, Kanticide, and Brainvashine. Cleveland: World"s Pubilshing Co., 1956. $320 \mathrm{pp}$.

Morgan, Ceorge Campbeli, D.D. The Great Rhustelans the Hethod of Jesus Wath Individuals. New Yorkt Whening H. Reve12 Co., 1937. $400 \mathrm{pp}$.

Nash, Jay B.. Ph.D. Reachable Honents; is Nov Anoroach te Health. Nev Yorkt H, S. Bames Co., 1930. 243 pp.

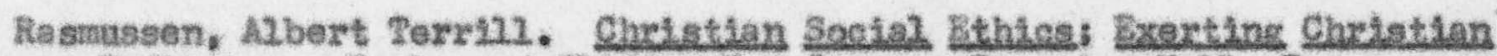
Infuemee. Englewood CILIfs, Now Jersey: Prentice-Ha2l, Inc. 1936. $21.8 \mathrm{pp}$.

Redi, Fritz, and David WIneman. Chuldren the Hate: the Disorcanization and Breakdorn of Bahevior Contrela. Qenco, Tu inois: Free Press, 1951. $253 \mathrm{pp}$.

Hogers, Carl, Ph.D. GlienteCentered Thorems: Its Currant Bractice, Innlieations and Theory. Sostons Houghton MLfflin Co., 1951. $559 \mathrm{pp}$.

Sryeg, Donald, and Arthur W. Canbs, Indivelduad Behsviox: a Nor Zroms

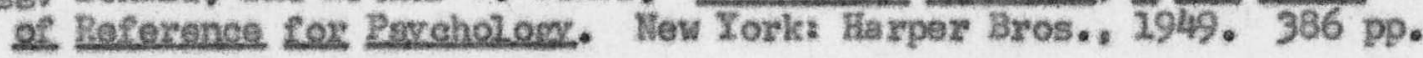




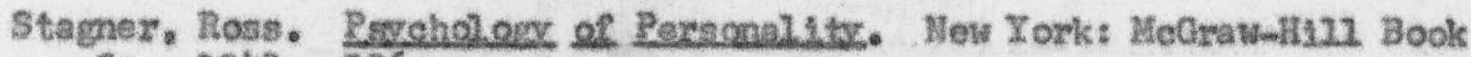
Co., 1948, $386 \mathrm{pp}$.

Stokes, John H., M.D. Dernatolosy and Synhulology Lor Wuxses, Includ-

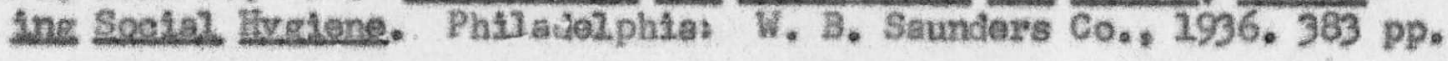

Symonds, Pereival H., Ph.D. Dunamile Bryeholecy. New York: AppletonCentury -Crof ts, Ine., 1949. 413 pP.

The Holy Buble. Authorized Kang James Version. Oxford: The Iniversity Press [n.d.].

The Hexck Hanual of Diamoris and Wherapy: a Source of Ready Reference

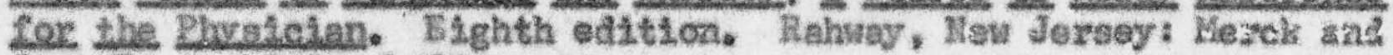
Co., Ino.. 1950. $1592 \mathrm{pp}$.

Tyler, Leona I. The Yoxk of the Counselor. Hew Yorkz Appleton-CenturyCrofts, Ine., 1953. 323 pp.

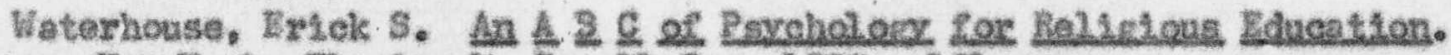
Nev York: Noming $H_{0}$ Reve11 $60 ., 1927.122$ pp.

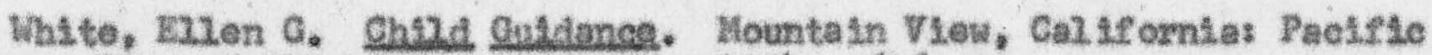
Press Publishing Association, 1954. $616 \mathrm{pp}$.

- Ghrist's Qblact Lessons. Mountain View, California: Pacirle Press Publishing Assoclation, 1900. 436 pp.

- Counsele on Haakth and Inatruction te Nedteal Maglonactes. Mounta in V Lev, Californta: Pacirle Press Publishing Assocletion, 1923. $696 \mathrm{pp}$.

- Counsels to Jeachers. Parents and Students. Hounts in VIew, Galifornia: Pacific Press Pubizehing Association, 1913. 574 pp.

- Sdueation. Mounta in Tlew, Callfornta: Paelfio Press PublishIng Assoolation, 1903, $320 \mathrm{pp}$.

- Rundunentals of Chriatian Iducation. Nash 1Me, Tennessoe: Southem PubiLshing AssociatLon, 2923. 576 pp.

- Kessaces to Zouns Reople. Nashvijle, Ternessees Southern Pubilshing Associstion, $2930.502 \mathrm{pp}$.

Batwlaxchs and Bxophete. Wounta in View, Californtat Pacteie Press Publishing Assoetation, 1913. 793 pp.

- Solvit of Brophecx. The Groat Gontrorerser Betreen Ghrist and Satan. Life and Mraclos of Dur Lord Jesus chretat. Vol. I of 3 
vols. Battle Creek, Michigani Stean Press of the Seventh-day Adventist Publishing Association, $1877.400 \mathrm{pp}$.

White, Blen G. Stens to Ghriat. Mountain V1ew, Californisa Factile Prese Publishing Assceletion, 1892. 144 pp.

Testimonies for the Chuxeh. Nine vols. Hountain VIew, Califamis: Paclife Press Fublishing Associa tion, various dates.

The Acts of the Anasties. Hountain View, Calleomia:

Pactelc Press Publtshing Assoeiation, 2912.630 pp.

The Destre of Aces. Hountain Vtow, Califomia: Pectrle

Press Publishing Assoclation, 2898. 863 pp.

The Zatith I Lve Bx. Washington, D.C.: Review and Merald Pubilishing Assoelation, 2958. 384 pp.

Whtte, Ernost, I.D. Christian LAfe and the Unconseloue. Now York Harpar Bros o, 1955. $290 \mathrm{pp}$.

Zabriskie, Loulse, R.X., and MLokolson J. Bastmen, K, D. Murses' liandbook of Obatetries. Ninth edition. Philadelphis: Lippineott Co., 1948. 695 pp.

\section{B. PERTODTCALS}

Chaptex Brchange, April, 1959, p. 4, Washington, D.C.t The Aneriean Semperance soctety.

DaLe, Glarenee W., K.D. "Wust I Be Hervous?" Revien and Hexn2d, Juno 2. 1955, p. 18.

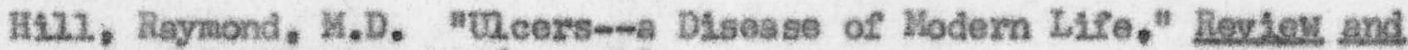
Heraid, 1ay 27, 1956, p. 28.

Jay, Arthur N., M.D. "Is It Indigestion?" Anerican Jaurnal of UlursIne, llovember, 1958, pp. 2552-54.

Podolsky, Edvard, M.D. "The Uleer Personality, "Wuselne World, August, 1950, pp. 362-63.

Sondern, Fredexio, Jx. "The Brainwashing of John Hays," The Readerts Digeat, July, 2955, pp, 27-32. 
c. UnPtDLISHED MA TERTALS

Prescott, Daniel A. "Role of Love in Eluman Developnent." (Unpubilshod manuseript.)

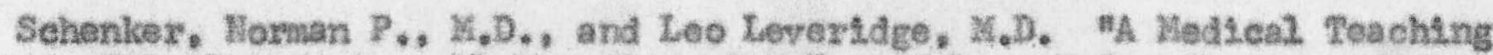
FLIm," made in colliaboration with llans Selye, M, D., Streas and the Adastation Brndronie. Brook1yn, New York: Prizer Laboratories.

Shryock, Harold, H,D. "Psychoblology for Students of fursing and Kedilclins." (Mineographed, 1943.) 
APPDUDXXS 
APPINDIX A

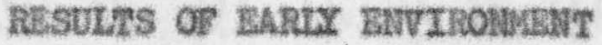

Personallty differonees are nariced during even the farst yeas of Ilfe. Sone varieties are, no doubt, dependent upon hereditary faetors, but the influence of environvent appears to be trenandous. To sone, the sugeestion that soctal expertences of babies vary greathy mey be surpelsing, because we tond to think of all bables as Itying such simple lives that differonces in expextence would be reduced to a minlmun.

In a study of 100 ono-year-ald bables that was undertaken for anothoz purpose, an informal record was kept of each baby s enotional. reactions to a sltuation in which he was encouraged to do sonething whleh required constderable effort on his part. Sone of the observethions are outlined in the follouting excerpts...

Entiy at the age of one year was a good-natured, healthy, happy beby, essent3ally nomal in pivsical developnent. When brought into the Laboratory she responded happily to strangers and seened inclined to invite then to frolis with her. Emily was plecad upon the floor - . . and a tog which she liked was placed boyond hor reach, She Iooked at the twy, inmedis tely pulied her forces together, and reached for it in a vigorous, alert way. She was placed in such a position that she had to clinb orer a four-inch bridge in order to reach any of the togs she wanted. She acetptied the situation anisbly, Iooked at the experimenter, and at her mother, and then with a grat effort el. Imbed upon the bridge and down again, resched the toy and salzed it la aghingly....

Julie presents an interesting contrast. When she was brought to the laboratory she elune to hor mother, al though she did not oxy when strangers approachod her. She went into the experimantal rocm quite wini ingly and was pleced upon the eloor with a toy just beyond has resch. Julte looked at the toy and lamediately her 1 ip began to quiver. She reached a pathetio 11ttle hand to her mother, turned appealingly to her, whimpered, and walted for her mothor to come to hor roscue....

Amne was a different kind of little porson. She vas serlous and undenonstretive while in the elinic. She left her mother without a protest and went with the examiner into the experimental room, al though her mother followed. When Anne was placed upon the Roor, with the toys just beyond her reach, she inmedistely made a great efforto erawied to get a toy, pleked 1 t up, examined 1 t seriously and denon- 
strated 21ttle foy at hor suecess. Amne was then placed behind the bridge with a toy on the oppostte side. She elinbed upon the bridge and dom agsin and crakled after the toy in the same sober, determined. gutet mannor that had charactertaed her behsvioy before. We wonlered If bustnosslike Anne wotild have not beon a different baby if she had Lived the flret yesx of her Ilfe under the guldance of froted. Julle's mother and father. ${ }^{2}$

I Bess V. Cunningham, Bsrcholoce for luxseg, pp. 233-35. 
APREMPIX $\mathrm{B}$

\section{DXPLANATION OF FIOURES}

The Ifigures show the effects of three different medications. These effects are produced through the nervous syatem. The 1ast one shows the differont rellex areas which are usad to gain results in hydrotherapy treatments. It w.12I be noted that morphine, for Instance, contracts the puplis whlle atropine d1lates them. This is because these drugs act on the brein center responsible for this funotion, and through the oculomotor nerves from the brean to the pup12s.

Korphine (Figure 2, page 71) causes vomiting in some persons because It stinulates the vomiting center in the medulla and the response reaches the stomach through the vagus nerves. On the other hand, atropine (rigure 3, page 72) Inhtbits the vagus nerves and lessons gastrio secretion and motility. Norphins inhibite the respiretory center, whlle atropine and caffolne (Figure 4, page 73) stimulate it.

These are only a few possibilities of effects to be obteined from the use of Just these three drugs, as ean be seen from stuty of the fleures. Bestdes thase, there are a great many more medioations which act in similar fashion to eure disease through the regulation of cunction.

Hydrotherapy, too (Figure 5, page 74 ), acts directly, through the nervous system. Lake the medicatlons diseussed, 1t acts on the brain centers and the $1 x$ extensions. It also acts upon reflex axeas. Function is stinulated or inhtbited by means of the temperatures used and the length of tholx appliteation.

Sane advantages of bydrotherapy are evident: it accomplishes Its rosults through external, application, 1 can be used locaizy, and Its generel effect is not toxic. Medieations are less selactive. When atropine is given to inhibit parasympathetie activity to the stonsch, the whole parasympathethe system is ineluded. Ary medieina is itinaliy destroyed by the Iiver, burned in the metaboilic processos, or exereted by the kidneys. When hydrotherapy is used on the livez it aets on its Iunctlon, but does not add torins to be destroyed. It increases metabolism to take oare of poiscns already present, but does not add others to be burned. When used in a way that increases kidney funethon, it holps throw off the toxins of disease, not the end products of matexsals that heve been given to comect some funotion. After a hydrotherang treatment theze Ls a feeling of well-belng, both montal. and phaseal, that gruge do not procuce. 
But medleatlons, too, have advantages. Their effects ean usually be kept constant, whlle hydrotherapy effeets pess off between treatmants. Whon there is great prostration, madications osn be glven whan exhausting troatwent would prove too vigorous. They can be used Ior quidk and effective stimulation when hydrotherapy would not be avaliable of vould bo too aloweating. Sonetlmas a feu doses of mediclne will. take hold and do whs th hydrothorapy seeme alnost impotent to do. There is aleo a realm of modical speclfles that are not duplteated in lydrotherapy, $21 k e$ the antiblotics in Infectlons and guinine in malarla. 


\section{APFSWIX C}

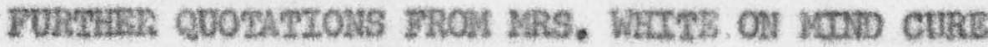

\section{NEDTCAL PRACTICE}

Nary seek medical advice and treatant tho have becone moral. wreeks through thelr own wrong hablts. They are brulsed, and wouk. and wounded, Leeling tha $1 x$ folly and their Inability to overcone. Such ones should have nothing in thelr surroundings to encourage a continuence of the thoughts and feel. Ings that have made them what they are. They noed to breathe an atmosphere of purity. of high and noble thought. ${ }^{2}$

The plyalcian neede nore than hwan wisdom and power that he nay know how to minister to the many pexplexing cases of disease of the mind and heart with which he is called to deal. If he Is Ipenorent of the poser of divine grece, he camnot holp the affliated one, but wIII ageravate the dufficul $4 y$, but if he has a IIm hald upon God, he w21. be able to help the diseased. distracted nind. He will be abie to point his patiente to Christ, and teach then to carry all. thoir caros and perplexteles to the great Burcen-bearer.

There is a divinely appolnted eonnection betweer sin and disease. Wo physteian cur practice for a nonth without seeing this 12lustreted. He may ignore the fact; his mind may be so occupled wath other matters that his attentlonwils not be ealied to it; but if he w111. be observing and honest, be cannot help acknotledeglug that sin and diseuse bear to each other the relationship of cause and erfect. The plystolan should be gutek to see this, and act accordingly. Whon he has gained the conflience of the afflicted by rolieving their sufferIngs and bringing them back Iran the verge of the grave, he ray teach them that disease is the resurt of sin: and thet lt 2 s the Iallen foe who seeks to allure them to hoalth-and-soul-destroying practices. He may impress their minds wlth the necessity of deny Ing sels, and obeying

the laws of Iife and health. In the minds of the young espectel.2y he may Instill wight prineiples. 2

Frankness in doaling with a patient insplxes him whth conflience, and thus proves an important ald to recovery. . . It may not always be safe or best to explain to the patient the full extent of his danger. Thts might alarm him and retard of even prevent recovery. Ior can the

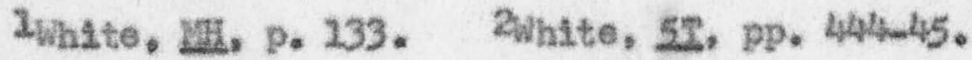


Whole truth always be told to those whose allments are largely Inaginary. Nary of these persons are unressonable, and heve not accustcmed themselves to exercise sels-comtrat. They have pecultar fencles, and Imagine many things that are false in regard to themselves and to others. To then these things are reel, and those who ande Ior them nead to manifest constant kindness and urweariad pationce and tact. If these patients were told the truth in regard to thomselves, sane wovld be offended, others diseouraged. Chrlst sald to His disciples. "I heve yot mary things to say unto you, but ye cannot boar then now," - Never shovid the piysteian or the nuree stoop to provarleation. He who does this places hinsele where God eamot comoperate wlth him and In forfelting the conildence of his patients, he is cagting away one of the most effective humen alds to their restoration?

On the pages of menoxy are sad historles that are saeredly eurded from curtous gyes. There stand regietered long, hard batt2es wth trying elreumetaness, porheps troubles in the hous $21 \mathrm{fe}$, that day by dey weaken courseg, confidenee, and fa 1th, Those who are IIfhting the battle of IIfe at great odds way be strengthened and encouraged by Iittie attentions that eost oniy a loving effort. To such the strong. helptul. eresp of the hand by a srue friend is worth more then gold, or sliver. Words of kindness are as welcona as the smiles of angels. 4

Great visston is needed in dealine with disedses caused through the mind. A sore, gick heart, a discouraged mind, needs mild treatment, Mary times some 1 iving hore trouble is, 1ike a eanker, ea ting to the very soul, and weskenting the lifeforce. And sometimes it is the case that, remorse for sin underuines the constitution and unbsiances the mind. It Is through tander sympathy that this class of Irval. Ils

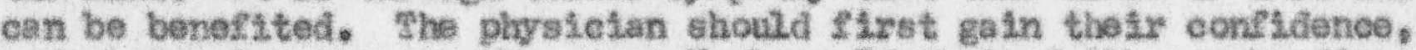
and then point them to the great Realex. If thelx Ialth can be directed to the true Plysician, and they can heve confldence that lio has undertaken their case, this w112 bring rolief to the matnd, and of ten give beal th to the body.

Sympathy and taet w21. often prove a grester benefst to the

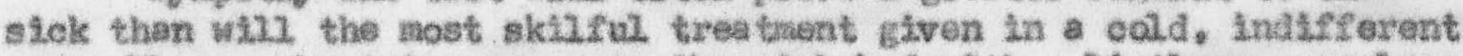
way. Whon a physteian comes to the sick-bed whth a 1lstless, careless mannex, Looks at the afriloted one with 21ttle concern, by word or ection giving the Impression thet the case is not one regulring much attention, and then Leaves tho patient to his own renections, he has done that patient posttzve hara. The doubt and diseouragement produced by his Indifference will often counterset the good effect of the remedies he ray preseribe. 5

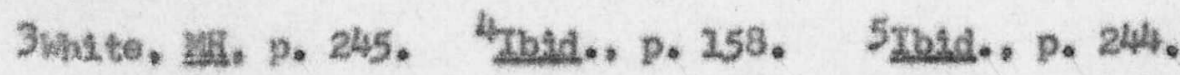


How IIttle we enter into gymathy with Christ on that which should be the strongest bond of untan between us and HLin,--compasstion for the depraved, gullty, sufforing souls, dead in trespasses and sins $3^{6}$

Whatevor the ev1. hablts, the strong prejudlces, or the overwhelning passion of huran beings, He not them all with pitying tendemess. As we partake of His Splrit, we shall regard all mon as brethren, w1th sinilia texptations and triels, of ten falling, and struggling to rise again, battilng with discouragermonts and difficulties, craving symgathy and bolp. Then we shall meet then in such a way as not to discourage or rcpel then, but to ataken hope in thoir hearts. As they are thus encouraged, they can say with confidense, "Rejolice not aga Inst me, 0 mine enery: whon I fall I shall arise again; when I slt in darkness, the Lord shall be a light unto me."?

We need nore of Christlike sympathy; not meroly sympathy for those who appear to be faul tless, but sympativ for poor, suffering, strugeling squls, who are of ten overtaken in favit, sinning and repentIng, tempted and alscouraged. We are to go to our followmen, touched, Iike our meredful fitgh Priest, with the feeling of their infirmities.8

6.04d.. D. 163.

7 patd. pp. 265-66. The Sertpture is Micah 7:8.

Brata: : p. 164 . 
Wabel KLopfensteIn G117, Paelile Union College, 1940.

Hoderm Concepts of Mind and Bocy In the Light of the Feaching of the Bible and the Writings of E12en C. White: A Comparative Study, * Wastar of Arts, Jume, 1959.

Duxpose of the studr. This study has been wade with the purpose of discorering what the writings of Elien $\mathrm{C}$. White contain on the subjeet of peychology. After considerablo exploration, so much naterial accumilated that $2 t$ became necessary to 1 init the subject to a single phase of paychology. The subject of mind and body has been chosen fron this material.

Brocedure. The originel procedure vas a syeterette reading of a22 the volumes of Krs. Khste's books ave12able, marking such passages as wers applicable. These wero then typed out and f trolly arranged in 1ogtesl. order under appropriste heade. For this thosis relevant quotathons were selected and the 1 r number reduced to the shortest and most pertinent ones. Notes from other authors vere kept, and as these two types of aourees were brought together it became necessary to rourd out the whole by consulting mary othez authorttieg. As developnents procoeded and nore aspects evolved, it was also neceseary to clarify these whth even further rosearch.

Kator Elndires. The major findings are listed below and folzon the order in which they are treated in the complete thesis.

1. As soon as sin entered, mind and body becans involved. Fear and guilt set up enotlonal reactions forelgn to the siniess state. It was these enotional reactions that eventualiy broke dow the 21fe Iorces and brought on disease and desth. 
2. The death of Christ resulted from both mental, and physteal surforing. The payment of the penalty wa a In accord w1th the Iraplications of the transeression.

3. Nind and body are so intimately connected thet the whole organism responds to every stinulus, whether $2 t$ is mentel or physical. at its corgan.

4. There are certain baste needs, needs in which e1ther rantal or physical predoninate, but in which both alwas co-operate. These needs are the sImple. physical needs connected with survival, and the emotlonal needs of securlty, recognition, Iore, and self-realization.

5. The nervous aystem, partieulariy the autonomise or imoluntaxy division, along with the endocrine gystem, are of outstanding importance in mind and body relationships. This is because they are so int2rately eorneeted wath the enotionnl eenters in the brain.

6. Vast Individual differonces extst in the eapseity to respond to stimult. These difleronces are lrherent in the constitutional make-up, espeolally the nervous systen. They have much to do with making Inititiduls susceptiblo or resistant to psychosonatio disease.

7. Not only is there a hereditary background for Individual differences, but environnent makes a large contribution to both plysieal and emotional developnent.

8. Ervironnent begins prenstally and moves along into the hane, then extends into the exvironmental eulture and mores outside the home. Iducation, rel.iglon, associations, and the occupetion all affect

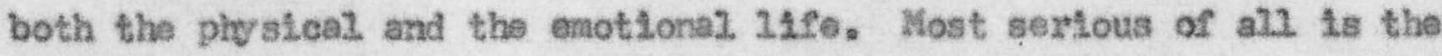


fact that the foundatione for mind and body well-being are being lasd so early that the Individual has not developed noral responst.b21.1ty. This nust bo assumed by the parents.

9. Right habits of thought aro as important to physieal health as they axe to the morsl. and Intellectual sapects of personality.

20. There are mind and body relations that are right, and there are sone that aro wrong. Domtnation, hypnotism, bratnwashtng, ali. allow a human being to Irvade the mind of another human being and are contrexy to moral sreedam.

12. Not only does the mind affeet the body, but the body affects the mind.

12. Disease began with sin and gu2l.t. Culite flgures largely in huras expextence, and since it is uncomfortable, mon heve found mary waya of dealling wtth 1t. But these ways are iradequate and 1110gieal. In Ohrist's ministry to the slek Ho donit with sin and gulut as well as sickness. His min'stry Ineluded both mind and boty.

13. S1ckness and dee th are the results of the transgresstons of the race, but there is also individual respensibility. The transgresstion of physical Law Plgures as a causa of both psychosomatie and plyateal disease.

Recormandations. Becase this research has proved so fruitful, and because there rense $n$ so many other posstbilities along the sane lines, the following recommendations are made.

1. Other aspects of psychology heve much material to offer. Child psyohology, adolescent psychology, and mary other phases of 
psychology are abundantiy represented In the writings of Mrs. White.

2. Thers are scattered statements on mentel. ability that could be callected and used In comnection with the subject of tests and measurements. Thls would make an interesting etudy, poss $2 b l y$ with less materlal than mamy other phases of psychology supply.

3. There axe valuable statements that could be complied and used In counsellng. referring both to the problems of the ellent and to the practice of counseling.

4. If Satan cones to the final generations through psychology. if he is pleased with the present-day study of this subject, as is stated In the writings of Mrs. White, it would be profitable to try to discores what his methods are, and how they are not in these books. 